\title{
State Water Resources Control Board \\ California Agreement in Principle \\ 1995 Summary Report
}

Section

Table of Contents

1.0 Introduction

2.0 Lawrence Livermore National Laboratory

3.0 Lawrence Livermore National Laboratory-Site 300

4.0 Sandia National Laboratory

5.0 Lawrence Berkeley National Laboratory

6.0 Stanford Linear Accelerator Center

7.0 Energy Technology' Engineering Center

8.0 Laboratory for Energy-Related Health Research

$$
\begin{aligned}
& D E-F G O 3-90 S F / 8800 \\
& \text { FMAL REPORT }
\end{aligned}
$$

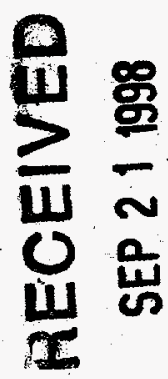

DASTRIBUTION OF THS DOCUMENT IS UMLMITED 


\section{DISCLAIMER}

This report was prepared as an account of work sponsored by an agency of the United States Government. Neither the United States Government nor any agency thereof, nor any of their employees, makes any warranty, express or implied, or assumes any legal liability or responsibility for the accuracy, completeness, or usefulness of any information, apparatus, product, or process disciosed, or represents that its use would not infringe privately owned rights. Reference herein to any specific commercial product, process, or service by trade name, trademark, manufacturer, or otherwise does not necessarily constitute or imply its endorsement, recommendation, or favoring by the United States Government or any agency thereof. The views and opinions of authors expressed herein do not necessarily state or reflect those of the United States Government or any agency thereof. 


\section{DISCLAIMER}

Portions of this document may be illegible in electronic image products. Images are produced from the best available original document. 


\title{
State Water Resources Control Board 1995 AIP Summary Report
}

\section{INTRODUCTION}

Prepared For:

UNITED STATES DEPARTMENT OF ENERGY OAKLAND OPERATIONS

\author{
Prepared By: \\ LESLIE LAAUDON \\ SENIOR ENGINEERING GEOLOGIST \\ STATE WATER RESOURCES CONTROL BOARD \\ DIVISION OF CLEAN WATER PROGRAMS \\ SACRAMENTO, CALIFORNIA
}

MARCH 1996 


\section{0 INTRODUCTION}

\subsection{BACKGROUND}

The Agreement in Principle (AIP) was established as part of the Secretary of Energy's Ten-Point Initiative which was announced in 1989. One of the Secretary's goals was to integrate the Department of Energy's (DOE) national security mission with their environmental restoration and compliance responsibilities. In an effort to accomplish this goal, DOE increased the role of the states in the oversight of DOE's monitoring programs through AIPs. The state of California and DOE negotiated the California AIP beginning in 1989 and signed the Agreement in September 1990. The original term of the California AIP extended until February 5, 1996. Due to budget cuts, DOE decided not to continue California's AIP Program after the original Agreement expired. AIPs between DOE and states other than California have been continued.

The California AIP provided technical and financial support to the state to conduct: 1) oversight of and independent verification of DOE's environmental monitoring programs for all environmental media; 2) emergency response preparedness planning activities between DOE and state and local governments to respond to potential on-site incidents at DOE facilities; and 3) public information and awareness programs to promote better public understanding of state oversight activities and environmental and health issues involving DOE facilities.

The AIP identified six DOE facilities to be evaluated under the program. The six facilities evaluated by the AIP program were:

1. Lawrence Livermore National Laboratory (LLNL) including LLNL's site 300

2. Sandia National Laboratories, California (SNL/CA) 
3. Lawrence Berkeley Laboratory (LBL)

4. Stanford Linear Accelerator Center (SLAC)

5. Energy Technology Engineering Center (ETEC)

6. Laboratory for Energy-Related Health Research (LEHR)

Because LLNL's main facility and site 300 are located in different geographic and hydrogeologic settings, the sites were considered separately by the SWRCB under the AIP and are discussed separately in this report.

During the AIP negotiations, the Department of Health Services (DHS) was identified by the Governor of California as the lead state agency for negotiating and implementing the Agreement. Initially, the Office of Emergency Services (OES) and the state Water Resources Control Board (SWRCB) also participated in the AIP Program. OES and DHS terminated their participation in the AIP Program in 1993 and 1995, respectively. The SWRCB assumed the lead agency responsibilities when DHS terminated their involvement. The SWRCB continued the water-quality components of the state's AIP Program for the remainder of the original grant period (through February 5, 1996). The SWRCB requested that DOE extend the timeframe of the AIP using unexpended carryover funds from the original grant. DOE denied the SWRCB's request, but did grant the SWRCB a 30-day extension to the Agreement timeframe for completion of this report and project close-out activities.

\subsection{PURPOSE OF REPORT}

This report summarizes the activities conducted by SWRCB staff during the calendar year 1995 to accomplish the goals of the AIP. This report also provides an overview of the water-quality issues that have been the focus of the AIP efforts at each facility and the related monitoring programs. The report provides a summary of the SWRCB staff's accomplishments during 1995 in the 
evaluation of the monitoring systems, methods, and sampling frequencies at the DOE facilities, and discusses the findings and recommendations from the evaluation. Specific activities, accomplishments, and recommendations conducted and developed in prior years of the AIP Program have been reported in previous annual reports.

This report was prepared to fulfill the reporting requirements of the AIP. DHS prepared a report: "I995 Annual Report, California Agreement in Principle" dated september 30, 1995 which detailed DHS staff's activities and recommendations. The DHS' report also identified specific activities, such as meetings attended, which involved SWRCB staff. Discussions of those specific activities are not repeated in this report. This report supercedes the portions of the DHS report regarding non-radiologic water-quality monitoring.

\subsection{SWRCB OBJECTIVES AND APPROACH}

The SWRCB and Regional Water Quality Control Boards (RWQCBs) are responsible for ensuring that the quality and beneficial uses of the state's water resources are protected. Until the beginning of the state's fiscal year 1994 (June 1, 1994), RWQCB staff assisted the SWRCB staff in program implementation. However, the non-regulatory nature of the AIP Program was difficult to separate from the regulatory responsibilities of the RWQCBs. Therefore, it was decided that the SWRCB would implement the entire water-quality components of the AIP Program. The RWQCBs secured alternative funding sources to support their regulatory activities at the DOE facilities. The SWRCB staff communicated and coordinated the AIP Program activities with RWQCB regulatory activities.

The objective of the SWRCB's component of the AIP Program was to 
assess the adequacy of current and proposed monitoring systems at DOE facilities to: 1) detect leakage of substances which could potentially degrade the quality of waters of the state,

2) characterize the hydrogeology and extent of known pollution at the site, and 3) determine the effectivene'ss of remedial actions to restore and/or protect water quality.

The AIP directed the state to independently evaluate the monitoring systems at the sites. To do this, data from a variety of sources were reviewed. These sources varied by site, but included the following: published geologic maps and references, aerial photographs, borehole logs and videos, chemical data, and reports and plans prepared by or on behalf of the discharger. Given the opportunity, SWRCB staff reviewed draft monitoring reports to identify potential deficiencies prior to the report's submittal to regulatory agencies.

Data from the sources mentioned above were independently reviewed, analyzed, compiled and graphically or spatially presented to illustrate relationships between data points. The relationships were interpreted to identify and analyze data trends to develop an understanding of the site conditions. Once a high level of confidence in the conceptual model was achieved by SWRCB staff, sampling points were evaluated to determine their value for maintaining or increasing the confidence in the site model. Data gaps were identified during the process at some sites, and additional monitoring may be needed to fill those gaps. At some sites, monitoring could be reduced without sacrificing improved understanding of site conditions.

Each site has unique characteristics and constraints which were considered in adopting an approach when evaluating the monitoring system at the site. These characteristics include physical features such as the geology, the chemical characteristics of the 
water, and the properties of the constituents of concern, schedules imposed by regulatory agencies, and limitations of current characterization and remediation technologies.

The goal of the monitoring evaluation was to ascertain whether there was a high degree of confidence in the conceptual hydrogeologic model of the site, as supported by the monitoring data. That is, the understanding of the hydrogeology, the pollution distribution, and migration parameters explain all of the collected data such that interpolation between data points and predictions regarding the system can be made with confidence. The monitoring networks at the sites were re-evaluated to develop recommendations to: eliminate duplicative or inappropriate sampling points or analytes and supplement the monitoring program with additional locations or analytes to fill data gaps.

A complete evaluation of all of the water-quality monitoring systems at all of the DOE sites was not completed during the term of the AIP due to resource and time constraints. SWRCB staff prioritized areas at the sites for focused evaluation. In some cases, the availability of data, and the level of cooperation from the site and DOE staff dictated the data that was reviewed and the work that was completed. As a result, each site was evaluated differently, depending to an extent upon the information available as a result of the phase of site characterization and/or remediation.

During 1995, SWRCB staff concentrated most of their efforts on three facilities: LEHR, ETEC, and SLAC. Correspondingly, the sections of this report that discuss those sites provide a more thorough monitoring evaluation.

SWRCB staff conducted limited independent monitoring at the DOE sites to verify the DOE or DOE-contractor's monitoring results. 
The DHS' Sanitation and Radiation Laboratory and the Central Valley RWQCB conducted the laboratory analyses for samples collected by the SWRCB staff. Some samples submitted to the RWQCB laboratory were analyzed by a contract laboratory. Prior to SWRCB sampling, SWRCB staff prepared or assisted DHS staff in preparing Project Monitoring Plans (PMPs). The PMPs identified the sampling and analysis techniques, quality assurance and quality control requirements, sample custody arrangements, etc. The PMPs were distributed to DOE and the DOE contractor at the site for review prior to initiating sampling.

SWRCB staff focused on ground water issues at most sites. However, an effort was underway by AIP staff to conduct stormwater sampling at some of the sites when the AIP Program was terminated. Automatic stormwater samplers that were purchased by the state for use in the AIP Program were installed by DOE or DOE-contractor staff at SLAC, SNL/CA, LBL and LEHR during 1995. Samples collected by the samplers were analyzed by the facility or DOE. At the termination of the AIP Program, those samplers were transferred to DOE for continued use at the facilities where they are installed.

During 1994, SWRCB ctaff advocated collection and analysis of water samples for the stable isotopes of oxygen and hydrogen from all of the sites and nitrogen for selected sites. DOE determined that the information obtained would likely be beneficial in determining hydrogeologic regimes at some sites. DOE approved the use of AIP funds for conducting limited stable isotope sampling. SWRCB staff assisted DHS staff in preparing a scope of work for the proposed study and contracted to implement the study. Sampling for stable isotope analysis was conducted by State AIP staff at several sites during 1995. Other sites initiated stable isotope studies independently of the AIP during 1994. Stable isotope sampling results, where available and 
collected by or provided to SWRCB staff, are discussed under the site-specific sections of this report.

\subsection{AIP ADMINISTRATION AND COORDINATION}

The Environmental Management Branch (EMB) of the DHS administered the AIP until October 1, 1995. The SWRCB staff provided assistance to the EMB in accordance with the AIP and an Interagency Agreement (IA). The SWRCB assumed lead agency responsibilities for grant administration following DHS' termination of their involvement in the program.

SWRCB staff conducted administration activities associated with the AIP Program. They maintained documentation of expenditures, budgets, activities and correspondence; supervised staff assigned to the program; and reported program progress to management. Clerical support was also provided to the technical staff.

Progress and Budget Reports were submitted quarterly to DHS for the first six months of the year as specified in the IA. Monthly progress reports were submitted for July and August, 1995 at the request of DHS. The progress reports outlined the time allocated to each site and activity, including site visits and report reviews, undertaken by SWRCB staff during the quarter or the month. The budget reports detailed expenditures by specific category during the quarter. This final summary report serves as the progress report to DOE for the time the SWRCB was the lead agency.

During 1995, SWRCB staff also prepared an Annual Summary Report for the 1994 calendar year. The report documented SWRCB and RWQCB activities during the year and presented findings and recommendations, based on the information analyzed at that time, for all of the DOE sites. The SWRCB Annual Report was included 
in the "Annual Report - California Agreement in Principle 1994" which was submitted to DOE by DHS.

The SWRCB staff participated in numerous meetings, both internal and with $E M B$, in order to coordinate AIP activities and to ensure that SWRCB obligations under the AIP were met. SWRCB staff also participated in coordination meetings with DOE and DOE-contractor staffs. Additionally, SWRCB coordinated with the RWQCB and other agencies involved in water quality issues including the U.S. Environmental Protection Agency, the Department of Toxic Substances Control (DTSC), the Department of Water Resources, local agencies, etc. The SWRCB staff acted as technical liaisons between the DOE/DOE contractor and EMB for water quality monitoring issues at the sites. SWRCB staff participation in AIP-related meetings was documented in the SWRCB's Quarterly Progress Reports and in DHS' 1995 Annual Report.

Communication and coordination difficulties plagued the AIP Program from its inception until its termination. Often, AIP Program staff were not informed of ongoing characterization or monitoring activities occurring or planned at a site, so the opportunity for AIP staff input was lost. Although the AIP was specifically a non-regulatory program, reviews of documents by AIP staff were often considered another layer of regulatory review. DOE, or their contractors, were reluctant to invite these reviews for fear of additional delays. Some sites embraced the AIP staff as team members and viewed the input as a valuable technical resource. At these sites, the AIP Program had the most success. Attempts were continuously made by AIP and DOE staff to resolve the communication and coordination problems. Improved communication was realized at some sites when quarterly AIP meetings were held. The schedule and scope of upcoming monitoring efforts and the appropriate role and level of effort of AIP personnel was often clarified at the meetings. 
AIP Program staff attended training classes, as deemed applicable, which was approved by the SWRCB AIP Program Manager or the appropriate supervisor. Table 1 contains a list of training classes SWRCB staff attended during 1995. The table identifies the number of staff attending, the length of the class and its location. This information is included in this report in response to questions raised during a DOE audit of the program regarding the SWRCB's training programs.

\begin{tabular}{|c|l|l|l|}
\hline \multicolumn{5}{|c|}{ Table 1 } \\
\hline Staff & \multicolumn{1}{|c|}{ Subject } & Length & Location \\
\hline 5 & Health and Safety Refresher & 8 hours & Sacramento \\
\hline 1 & $\begin{array}{l}\text { Diagnosis and Remediation of } \\
\text { DNAPL Sites }\end{array}$ & 4 days & San Francisco \\
\hline 4 & $\begin{array}{l}\text { SwRCB sponsored ARARs } \\
\text { Training }\end{array}$ & 3 days & Riverside \\
\hline 4 & Time Management & 1 day & Sacramento \\
\hline 1 & Technical Writing & 1 day & Sacramento \\
\hline 5 & $\begin{array}{l}\text { SwRCB sponsored ground water } \\
\text { modeling training }\end{array}$ & 1 day & Sacramento \\
\hline
\end{tabular}

\subsection{PUBLIC RELATIONS}

While the SWRCB did not develop a formal public awareness and participation plan as a component of the AIP program, SWRCB staff availed themselves to concerned citizens on an individual basis. In some cases, SWRCB staff met individually with neighbors of the DOE sites to discuss their concerns. Additionally, SWRCB staff 
participated in community meetings at the DOE sites when waterquality issues were discussed. SWRCB staff kept DOE apprised of public relations activities.

\subsection{REPORT FORMAT}

This Introduction section of the report outlined non-site specific activities and provided an overview of the objectives and approach taken by SWRCB staff in evaluating the monitoring programs at the DOE facilities. The following sections are individual reports for each of the DOE facilities which summarize site-specific activities, monitoring data, findings and recommendations. The format and detail of each section differs depending on the extent of analysis performed during 1995. 


\author{
State Water Resources Control Board \\ 1995 AIP Summary Report
}

LAWRENCE LIVERMORE NATIONAL LABORATORY

\author{
Prepared For: \\ UNITED STATES DEPARTMENT OF ENERGY \\ OAKLAND OPERATIONS \\ Prepared By: \\ DENNIS PARFITT \\ ASSOCIATE ENGINEERING GEOLOGIST \\ STATE WATER RESOURCES CONTROL BOARD \\ DIVISION OF CLEAN WATER PROGRAMS \\ SACRAMENTO, CALIFORNIA
}

MARCH 1996

11 


\subsection{INTRODUCTION}

The State Water Resources Control Board's AIP activities related to the Lawrence Livermore National Laboratory in 1995 consisted of three "Team Building" meetings with DHS, DOE, and LLNL staff, a meeting with LLNL technical staff to discuss site stratigraphic relationships, and assisting DHS in the preparation of a ground water Project Monitoring Plan (PMP). . The objectives of the "Team Building" meetings were to identify specific AIP-related tasks that would augment LLNL environmental monitoring and remedial activities. The PMP was being prepared to specify ground water sampling procedures and protocols for anticipated AIP sampling activities at the site. As a consequence of the decision by DHS to withdraw from the AIP program, "Team Building" activities halted and preparation of the PMP was terminated.

\subsection{ADEQUACY OF GROUND WATER MONITORING SYSTEM}

An evaluation by SWRCB AIP staff of the adequacy of the ground water monitoring system at the LLNL facility was proposed to be completed during the 1995 calendar year. Much of the preliminary data review and analysis had been completed by the end of 1994 . Improving communications and cooperation on the part of the LLNL staff and management fostered a sense of optimism. In June, AIP staff were briefed by LLNL staff on their success in identifying stratigraphic units and the relationship which exists between the distribution of pollutants in each unit, the area where the unit intercepts the water table, and the location of known pollution sources.

The DHS decision to withdraw from the AIP program resulted in the 


\begin{abstract}
redirection of the focus of SWRCB efforts. SWRCB staff shifted their focus to the evaluation of DOE facilities which were deemed to constitute a higher priority in terms of public health and safety. Because the AIP evaluation of the adequacy of the monitoring. system at LLNL is incomplete, we cannot state that all sources of pollution at the facility have been identified or investigated by DOE/LLNL.
\end{abstract}




$$
\begin{aligned}
& \text { State Water Resources Control Board } \\
& 1995 \text { AIP Summary Report }
\end{aligned}
$$

LAWRENCE LIVERMORE NATIONAL LABORATORY-SITE 300

\author{
Prepared For: \\ UNITED STATES DEPARTMENT OF ENERGY \\ OAKLAND OPERATIONS \\ Prepared By: \\ DENNIS PARFITT \\ ASSOCIATE ENGINEERING GEOLOGIST \\ STATE WATER RESOURCES CONTROL BOARD \\ DIVISION OF CLEAN WATER PROGRAMS \\ SACRAMENTO， CALIFORNIA
}

MARCH 1996 


\subsection{LLNL SITE 300}

\subsection{INTRODUCTION}

State Water Resources Control Board AIP activities related to LLNL SITE 300 in 1995 consisted of three "Team Building" meetings with DHS, DOE, and LLNL staff and assisting DHS in the preparation of a ground water Project Monitoring PIan (PMP). The objectives of the meetings were to identify specific AIP-related tasks that would augment LLNL environmental monitoring and remedial activities. The PMP was being prepared to specify ground water sampling procedures and protocols for anticipated AIP sampling activities at the site. Due to the decision by DHS to withdraw from the AIP program, "Team Building" activities halted and preparation of the PMP was terminated.

A thorough evaluation of the off-site ground water monitor system in the General Services Area of the site was completed in 1993 (Parfitt 1993). At that time SWRCB AIP staff expressed concerns about the hydrogeologic conceptual model presented by LLNL and the presentation/interpretation of data used to rationalize the model in their Draft site-Wide Remedial Investigation Report (LLNL 1993). SWRCB AIP staff recommended that a shallow monitoring well be installed west of the site's sewage treatment pond and that a previously unidentified spring located about a half mile north of Castle Rock and near the east side of Corral Hollow Road be included in future environmental sampling.

In August 1994, SWRCB AIP staff reiterated the desire to obtain water samples at the spring and proposed to install a shallow monitoring well (four to five feet deep) near the spring for that purpose (Parfitt 1994a). LLNL staff, in November, responded to the AIP proposal for the shallow well and concluded that any data 
gained by its installation would not significantly enhance the understanding of the ground water plume and that such work could not be justified on the basis of cost (Lamarre 1994). In response to LLNL, AIP staff again explained its views on the deficiencies of the LLNL hydrogeologic conceptual model and the contradictory interpretations of data used to rationalize LLNL's conclusions. AIP staff proposed, in light of LLNL's concern for costs, that AIP staff perform the well installation work and associated sampling (Parfitt 1994b). In June 1995 DOE/LLNL staff agreed during a "Team Building" meeting that DOE/LLNL would install the well and set a tentative work date of August/September 1995.

\subsection{ADEQUACY OF GROUND WATER MONITORING SYSTEM}

As of this report, no further progress has been realized with respect to acceptance of the AIP staff recommendation to monitor ground water near the spring located on the east side of Corral Hollow Road. The current GSA monitoring system, without the proposed well and the ground water quality data it would provide, does not adequately characterize the extent of off-site ground water pollution in Corral Hollow. DOE/LLNL has acknowledged their commitment to taking a sample at the spring located near the east side of Corral Hollow Road during a "Team Building" meeting in June, 1995. However, due to our workload and the weather, the sample has not yet been taken. DOE/LLNL plan to take a sample in spring of 1996.

\subsection{RECOMMENDATION}

A shallow ground water monitoring well should be constructed near the spring located near the east side of Corral Hollow Road. Ground water samples from the well should be analyzed for general mineral and chlorinated volatile hydrocarbons. 


\subsection{REFERENCES}

LLNL, 1993. Draft Site-Wide Remedial Investigation Report, Lawrence Livermore National Laboratory Site 300. August 1993

Lamarre, A., 1994. Memorandum to Mike Brown, November 15, 1994

Parfitt, D., 1993. Memorandum to J. Adams, December 31, 1993.

Parfitt, D., 1993a. Memorandum to K. Jackson, September 13, 1993.

Parfitt, D., 1993b. Memorandum to K. Jackson, December 27, 1994. 


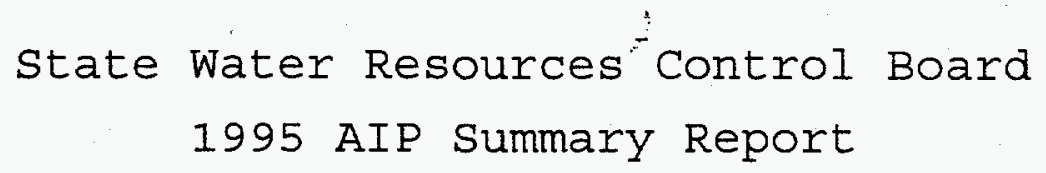

Prepared By:

DENNIS PARFITT

ASSOCIATE ENGINEERING GEOLOGIST STATE WATER RESOURCES CONTROL BOARD DIVISION OF CLEAN WATER PROGRAMS SACRAMENTO, CALIFORNIA

MARCH 1996 


\subsection{SANDIA NATIONAL LABORATORY}

\subsection{INTRODUCTION}

State water Board AIP activities related to SNL in 1995 consisted of the development of a proposal for the modification of the site's ground water sampling plan for the Navy Landfill (NLF) area and Arroyo seco (AS) monitoring wells (Parfitt, 1995). The proposed modifications addressed the frequency of well sampling and was based on an evaluation by AIP staff of the adequacy of the ground water monitoring system in 1994.

As a consequence of the decision by DHS to withdraw from the AIP program, planned activities, including the sampling of private water supply wells in the vicinity of the SNL site and an analysis of Fuel Oil spill area monitoring system, were deferred.

\subsection{ADEQUACY OF GROUND WATER MONITORING SYSTEM}

The 1994 AIP evaluation consisted of the development of a hydrogeologic conceptual model, a review of historic water quality analyses, and an analysis of the construction and placement of the monitoring wells. AIP staff concluded that the ground water monitoring system for the Navy Landfill was adequate. As follow-up to the 1994 evaluation, AIP staff concluded that the entire suite of analytes tested for each quarter and that the frequency of sampling and reporting was excessive given the Landfill's hydrogeologic setting and the potential to impact public health and the environment. The proposed modifications would result in an estimated $60 \%$ reduction in the costs of sampling and reporting. 


\subsection{RECOMMENDATIONS}

Initiate, with Regulatory approval, the 1995 AIP recommendations for ground water monitoring at the NLF and AS monitoring wells. 


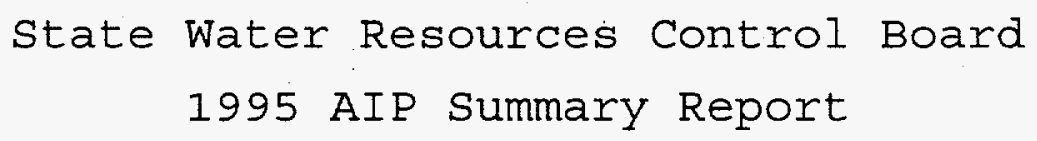

\title{
LAWRENCE BERKELEY NATIONAL LABORATORY
}

\author{
Prepared For: \\ UNITED STATES DEPARTMENT OF ENERGY \\ OAKLAND OPERATIONS \\ Prepared By: \\ CHUCK NESMITH \\ ASSOCIATE ENGINEERING GEOLOGIST \\ STATE WATER RESOURCES CONTROL BOARD \\ DIVISION OF CLEAN WATER PROGRAMS \\ SACRAMENTO， CALIFORNIA
}

MARCH 1996 


\subsection{LAWRENCE BERKELEY NATIONAL LABORATORY}

\subsection{EXECUTIVE SUMMARY}

Under the Environmental Restoration Program (ERP), extensive site investigations have been conducted at LBNL to identify and remediate releases of hazardous chemicals and radionuclides at the facility. The ERP has utilized nearly every investigative tool currently available.

The results of these investigations show that the bulk of soil and ground water pollution at the site is a consequence of releases of chlorinated hydrocarbons. Low levels of tritium have also been found. The three main areas of ground water pollution at the site are in the "Old Town" area, the Building 71 area, and near the National Tritium Labeling Facility (NTLF).

The extent of ground water pollution in both the "Old Town" area and Building 71 has essentially been defined. Current and proposed treatment systems for the "Old Town" plume should be effective in containing further migration of pollutants and will also provide some ground water cleanup through pump and treat methods. The Freon 113 plume near Building 71 consists only of low levels of Freon 113 (below the MCL) and these levels are decreasing over time. No further action, except for continued monitoring according to the current schedule, is recommended for this plume.

The plume of VOCs in the southern area of Building 71 consists of only low levels of Vocs that probably resulted from spills in the Hazardous Materials storage area. Hydraugers in the area carry some of the polluted ground water to a treatment system. No further action is recommended for this area except for continued monitoring according to the current schedule. 
Low levels of tritiu

$$
\text { Cince NTLF is currently }
$$
water near the NTLF. allowed emission of As long as emissions allowed, low levels ground water. Howev problem since tritiu tom porarily shutdown, it $B$ expected the Tritiun * could ato be decreased.

lized in ground water at LBNL is not enough to allow for boundaries.

s the legally

NTLF stack. the stack are in the nearby is not a , the ground ow is slow reaches site

Perimeter wells have been installed along the downgradient (south through west) boundary of LBNL and, except for well MWP-7, no VOCs have been confirmed in these wells. The VoC concentration in MWP-7. is slightly above the MCL and ground water from this area is being pumped and treated to prohibit offsite migration. Two off-site wells are included in quarterly sampling for voCs and these also have not contained confirmed VOCs.

Comparison sampling for VOCs conducted by the AIP has shown no significant discrepancies between ERP and AIP results.

\subsection{INTRODUCTION}

GENERAL

The Lawrence Berkeley National Laboratory (LBNL) occupies 134 acres located northeast of the University of California at Berkeley, on the western side of the Berkeley Hills (Figure 1). The LBNL has operated there since 1942. Its main functions are research in nuclear and high-energy physics; accelerator research and development, materials research, and in chemistry, geology, molecular biology and biomedical research. 


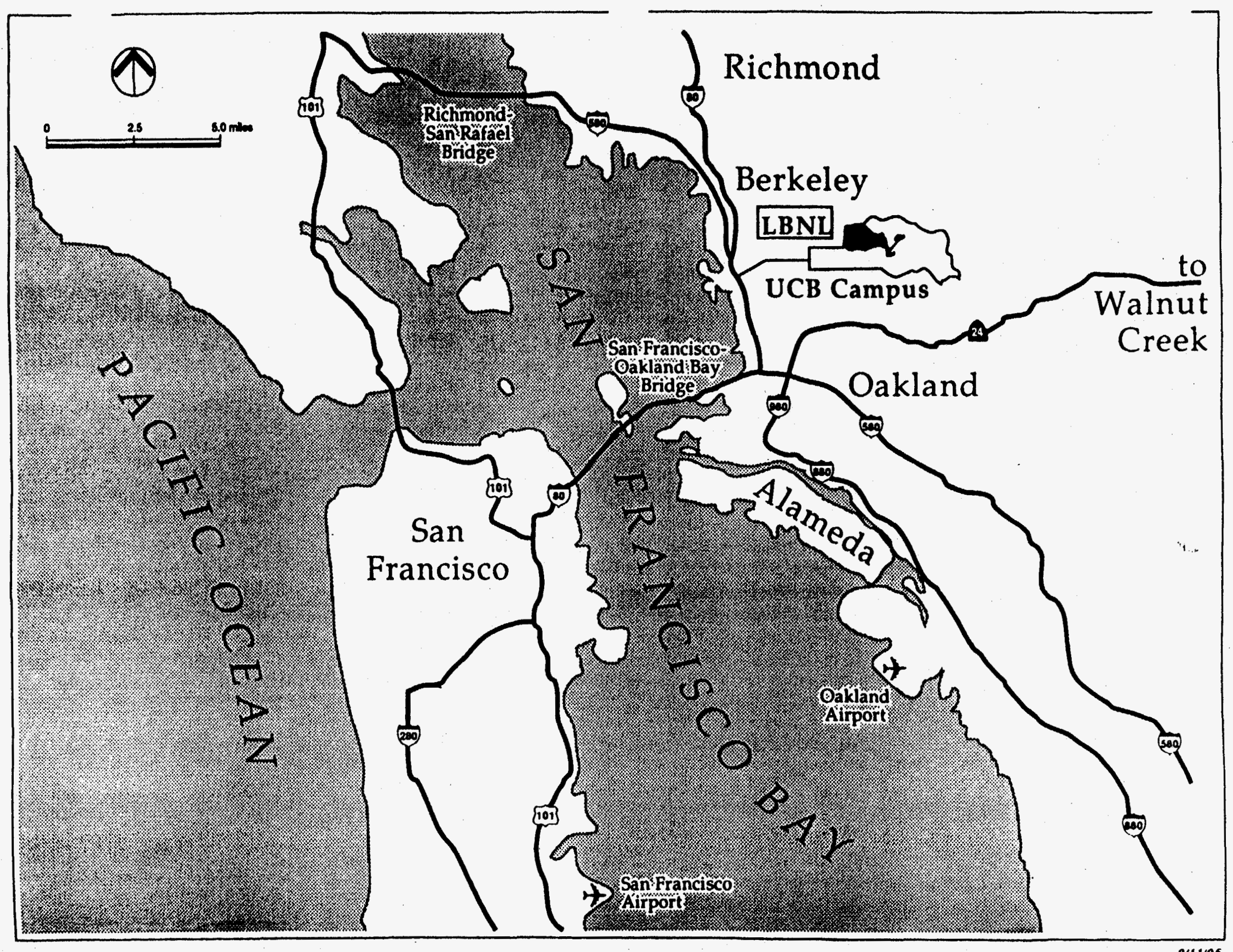

Figure 1. Location map for LBNL. Modified from LBNL (1994). 
The LBNL maintains a ground water monitoring program designed to monitor releases of hazardous chemicals and radionuclides into ground water under the ERP. Initial site investigations, which included ground water sampling, began in 1986 during a routine environmental study, prior to expansion of the facility. Low levels of trichloroethene (TCE) and perchloroethene (PCE) were detected in samples taken from the effluent of two adjacent hydraugers. During the ensuing years, further site investigations were conducted and additional releases of hazardous chemicals and radionuclides to the soil and/or ground water were discovered. A carbon treatment system was installed to remove solvents from hydrauger discharges.

In order to obtain a National Pollutant Discharge Elimination System (NPDES) permit from the San Francisco Bay Regional Water Quality Control Board (RWQCB) for discharge of the treated ground water to the storm drain, LBNL was required to fully investigate the vertical and lateral extent of all ground water pollution at LBNL. The LBNL began quarterly ground water monitoring in 1992 . It also conducts site investigations as part of its RCRA Part $B$ Hazardous Waste Facility Permit issued by the Department of Toxic Substances Control.

In the process of conducting site investigations, 109 on-site and one off-site ground water monitoring wells have been installed. The 134-acre site has been divided into 15 areas (Figure 2) to help locate, describe, and report environmental activities. These boundaries however, do not necessarily separate ground water plumes (i.e. those originating from different sources), and multiple sources may be present within each area.

Soil and ground water environmental investigations at LBNL have been extensive since 1990 when the LBNL Environmental Restoration Program (ERP) was formed. The ERP has utilized nearly every 


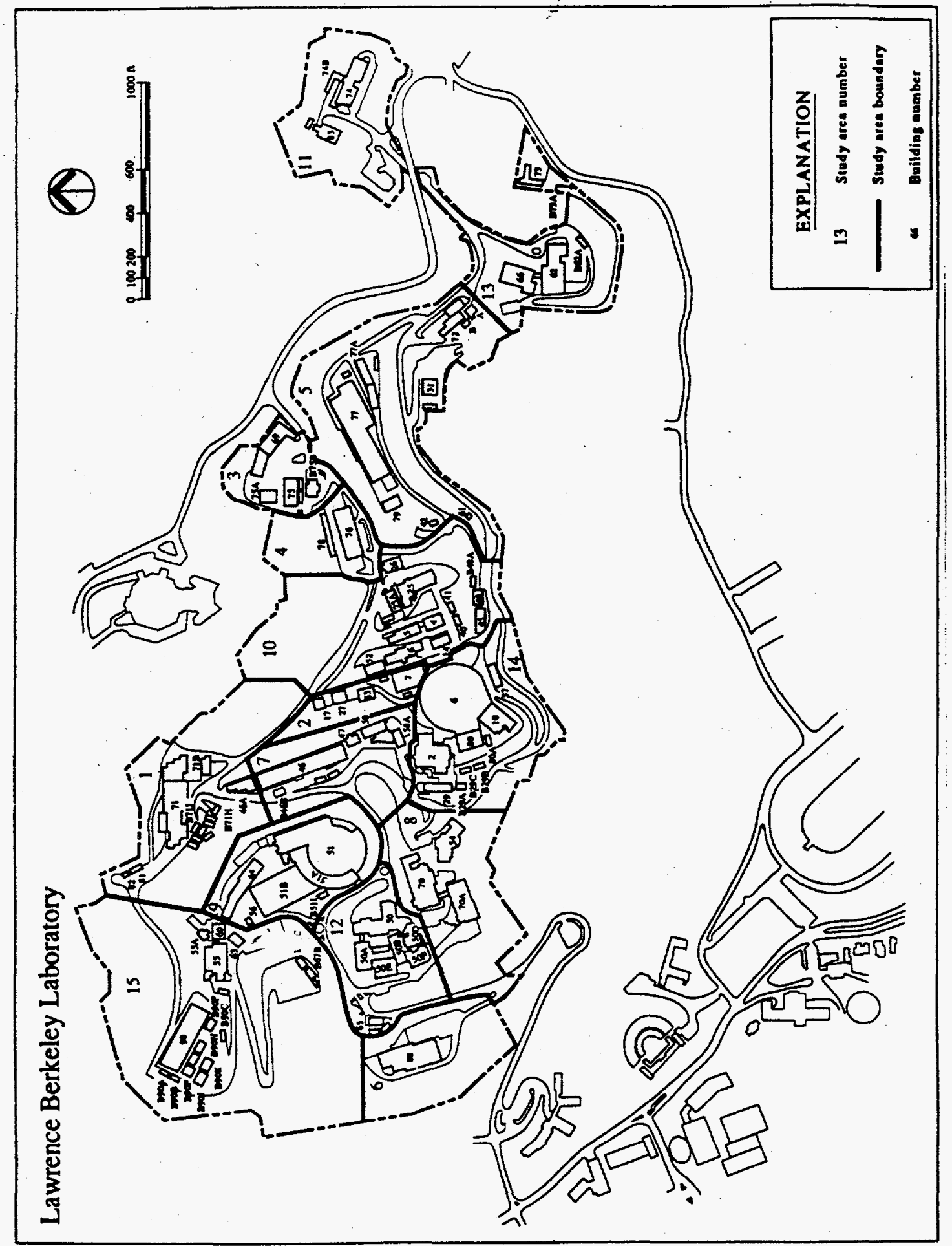

Figure 2. Map of IBNL showing the 15 areas in which the site was divided for the purpose of reporting site investigation activities. Modified from LBNL (1994). 
investigative tool currently available including: I) thorough records research for past site activities that may have caused releases of hazardous materials, 2) study of the site infrastructure to determine the location of man-made pollutant migration pathways such as hydraugers, sewer lines, filled stream channels etc., 3) soil gas sampling, 4) soil borings and soil sampling, 5) installation of monitoring wells and monitoring well clusters for ground water sampling, 6) aquifer testing through slug tests and pumping tests, 7) tracer tests to monitor ground water flow, 8) stable isotope sampling to identify ground water sources (also used as a tracer), 9) geophysical surveys to evaluate the vadose zone and to determine subsurface geologic structure, and 10) thorough computer analysis of the data including state-of-the-art ground water modeling.

All of these tools have been needed to investigate adequately the numerous releases at LBNL, since the subsurface at the site is very complex due to the intricate subsurface infrastructure and underlying fractured/faulted bedrock. The geology is made even more complex by the presence of paleo-landslides and unconformable rock units.

Site cleanup activities have included soil excavation and removal, and ground water pump and treat systems. The latter are used to contain ground water plumes (low level vocs) that may otherwise flow off-site, or migrate further downgradient.

PURPOSE AND SCOPE

The purpose of this report is to provide a detailed evaluation of the adequacy of the environmental ground water monitoring system at LBNL. Three basic factors were considered in this evaluation: 
1. Nature and extent of $\operatorname{spill}(\mathrm{s})$, leak(s), waste disposal activity etc.

2. Regional and local hydrogeologic conceptual model. This includes evaluation of ground water movement, recharge and discharge, and the geologic factors which affect them.

3. Location and construction of monitoring wells.

However, due to time constraints SWRCB staff were unable to evaluate every monitoring well and every release at this site. Therefore, this report focuses on the major releases at the site and those areas or constituents which are of the greatest public concern. These include:

1. The "Old Town Plume" located in Area 2.

2. The Building 71 plume located in Area 1.

3. Tritium in ground water in Area 3.

4. Perimeter wells on the downgradient (south through west) boundaries of. LBNL.

In addition to reviewing site investigation documents prepared by the ERP, AIP staff also conducted comparison ground water sampling, which included well clusters 53-93-16 and 53-93-21, and wells 71-93-1, 71-94-1, CD-92-28. AIP staff also installed continuous water level recorders (Stevens Recorders) at wells 53-93-16 (4" well) and 6-95-14 in early November 1995 and removed them in mid-January 1996. 


\subsection{BACKGROUND}

\section{SITE GEOLOGY}

The Berkeley Hills on which LBNL is located are characterized by moderate to locally steep relief, modified by erosion of several steep stream canyons, by landslides, and by cut and fill operations during construction of the facility. Figure 3 shows the location of the main streams which flow across LBNL.

Although five distinctive geologic formations are exposed at the site (Figure 4) three of them compose the bulk of the bedrock site geology and virtually all of the release areas discussed in this report. In order of decreasing age, these three rock units are:

1. Great Valley Group - - The Great Valley Group is comprised of Cretaceous marine mudstones, sandstones, and shales which are exposed at the lower elevations of LBNL (LBNL, 1994).

2. Orinda Formation -- The Orinda Formation is included in the Miocene Contra Costa Group and consists of non-marine sandstones, mudstones, and conglomerates deposited in alluvial-fluvial environments. At LBNL, the much younger Orinda Formation overlies the Great Valley group in either fault or unconformable contact.

3. Moraga Formation - - The Moraga Formation is also included in the Miocene Contra Costa group and consists of mostly lava flows, flow breccias, and agglomerates. Moraga rocks overlie the orinda formation in conformable contact in some areas, and unconformable contact in others. Where the contact is conformable, lava flows are intercalated with 


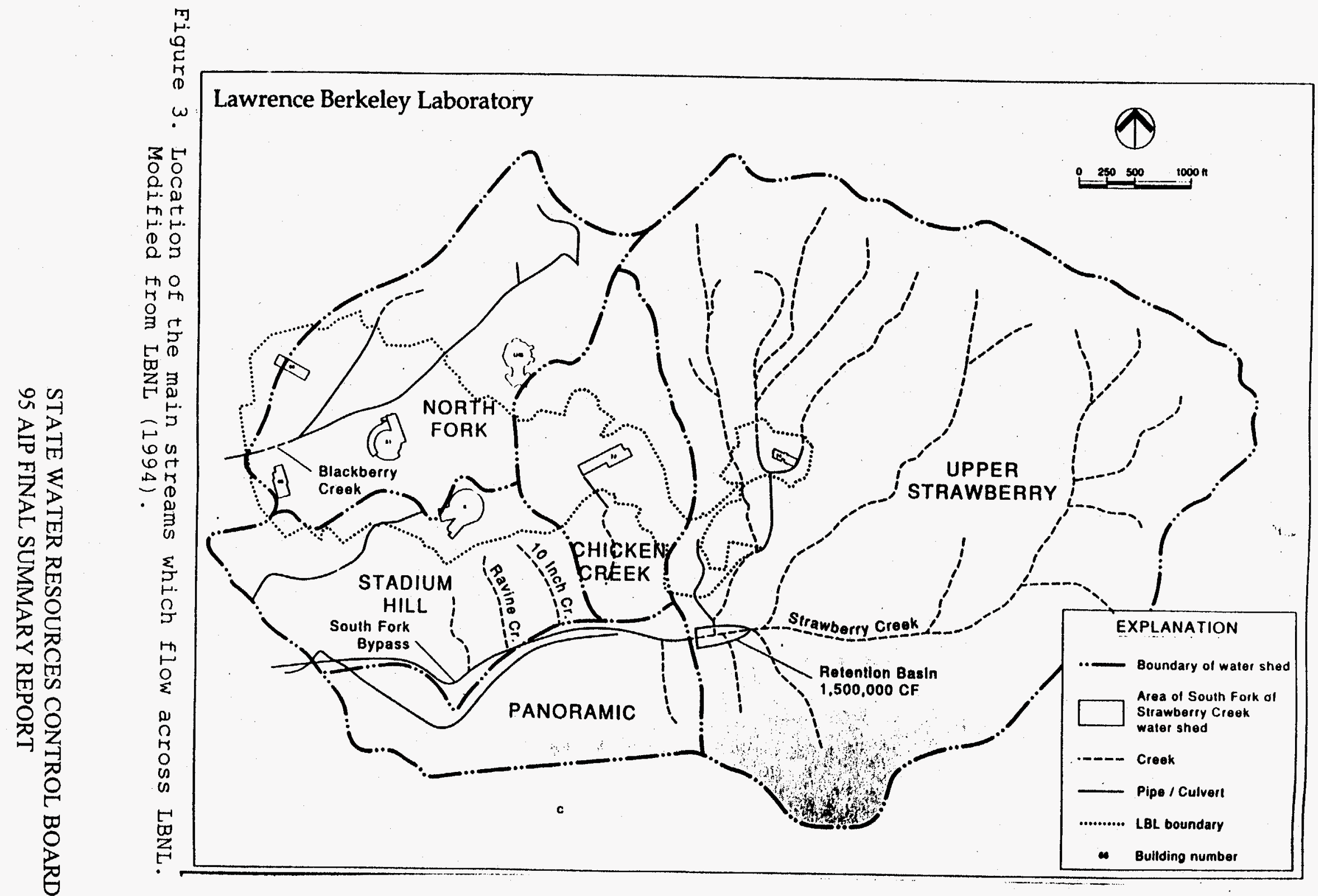




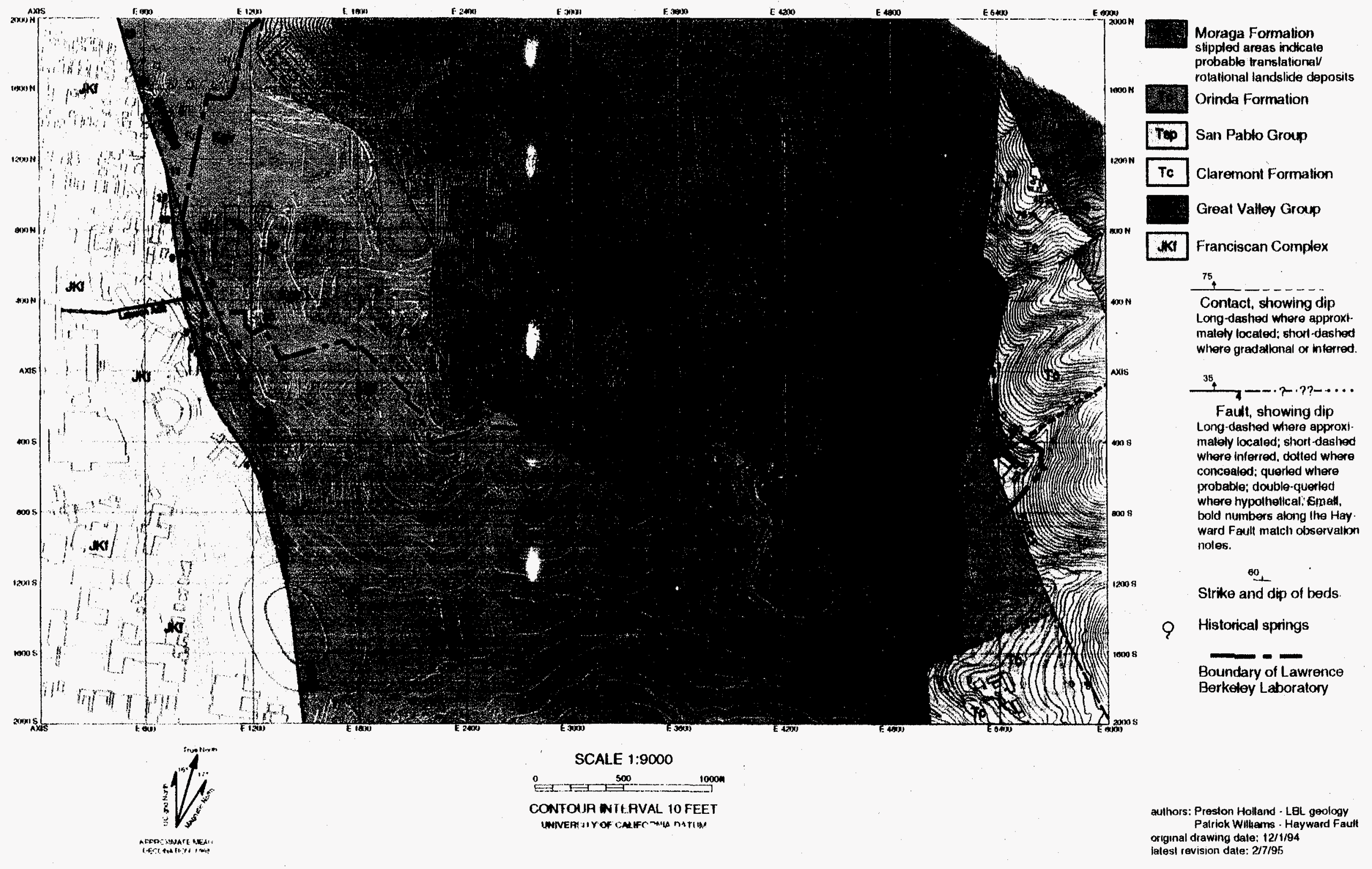

Figure 4. Bedrock geologir map of LBNL. Modified from LBNL (1995). 
Based on the extensive data gathered from well installations, slug and pumping tests, and periodic water level measurements, the hydrogeologic characteristics of the relevant rock units are as follows:

1. Great Valley Group - Flow is dominantly controlled by fractures and reported hydraulic conductivities range from $10 \mathrm{e}-2 \mathrm{~cm} / \mathrm{sec}$ to $10 \mathrm{e}-5 \mathrm{~cm} / \mathrm{sec}$. Permeability is lowest where fractures are closed or filled with clay material from the overlying orinda Formation.

2. Orinda Formation -- Flow is dominantly controlled by matrix and reported hydraulic conductivities range from $10 e-5$ to $10 \mathrm{e}-7 \mathrm{~cm} / \mathrm{sec}$. Areas of higher reported hydraulic conductivity $(10 \mathrm{e}-2$ to $10 \mathrm{e}-4 \mathrm{~cm} / \mathrm{sec})$ in the Orinda Formation are present in wells screened across isolated zones of pebbly sandstones.

3. Moraga Formation - - Flow is dominantly controlled by fractures and reported hydraulic conductivities are relatively high $(10 \mathrm{e}-2$ to $10 \mathrm{e}-4 \mathrm{~cm} / \mathrm{sec})$. The Moraga formation constitutes the main water bearing unit at LBNL.

The depth to ground water in wells at LBNL ranges from ground surface (springs) to 115 feet below grade, however, depth most commonly ranges from 20 to 60 feet below grade.

The ERP has attempted to measure vertical flow of ground water by the installation of well clusters, which are a set of wells in the same location, screened at different intervals. These wells are sealed off from each other to prevent leakage between wells. stabilized water level information from a well cluster can determine if ground water has any vertical component of flow. However, ground water has not yet stabilized in the main well 
cluster installed for this purpose (53-92-21) though the wells are screened in relatively more permeable sections of the orinda Formation.

Ground water recharge at LBNL results mainly from rainfall, however, small contributions are due to effluent streams and leaks of fresh water from the facility. The latter has been determined by stable isotope analysis of samples from several wells at the site (see DHS AIP Final Report).

CHRONOLOGY AND POLLUTION DISTRIBUTION

"Old Town Area"

The area known as "Old Town" at LBNL covers all of Area 2 and portions of Areas 7, 10, and 14 (Figure 6). The main source of soil and ground water pollution (from solvents) at the site were discovered in 1992 when an abandoned sump and a cement-lined ditch were discovered between buildings 7 and 7B. Residual solvent and bottom sediment were still in the sump and subsequently removed along with the soil that was covering the ditch. The sump was backfilled with gravel and slotted casing was installed to remove inflowing rain and surface runoff.

Since this discovery, extensive soil and ground water investigations have been conducted to define the extent of pollution, as well as to identify areas for interim remediation. Figure 6 shows the location of monitoring wells that had been installed in the "Old Town" area as of June 1995. Since that time, 16 additional wells have been installed in "Old Town". The bulk of wells installed in the area are centered around the Building 7 sump.

When well MW-7B-95-21 was installed a few feet north of the sump 


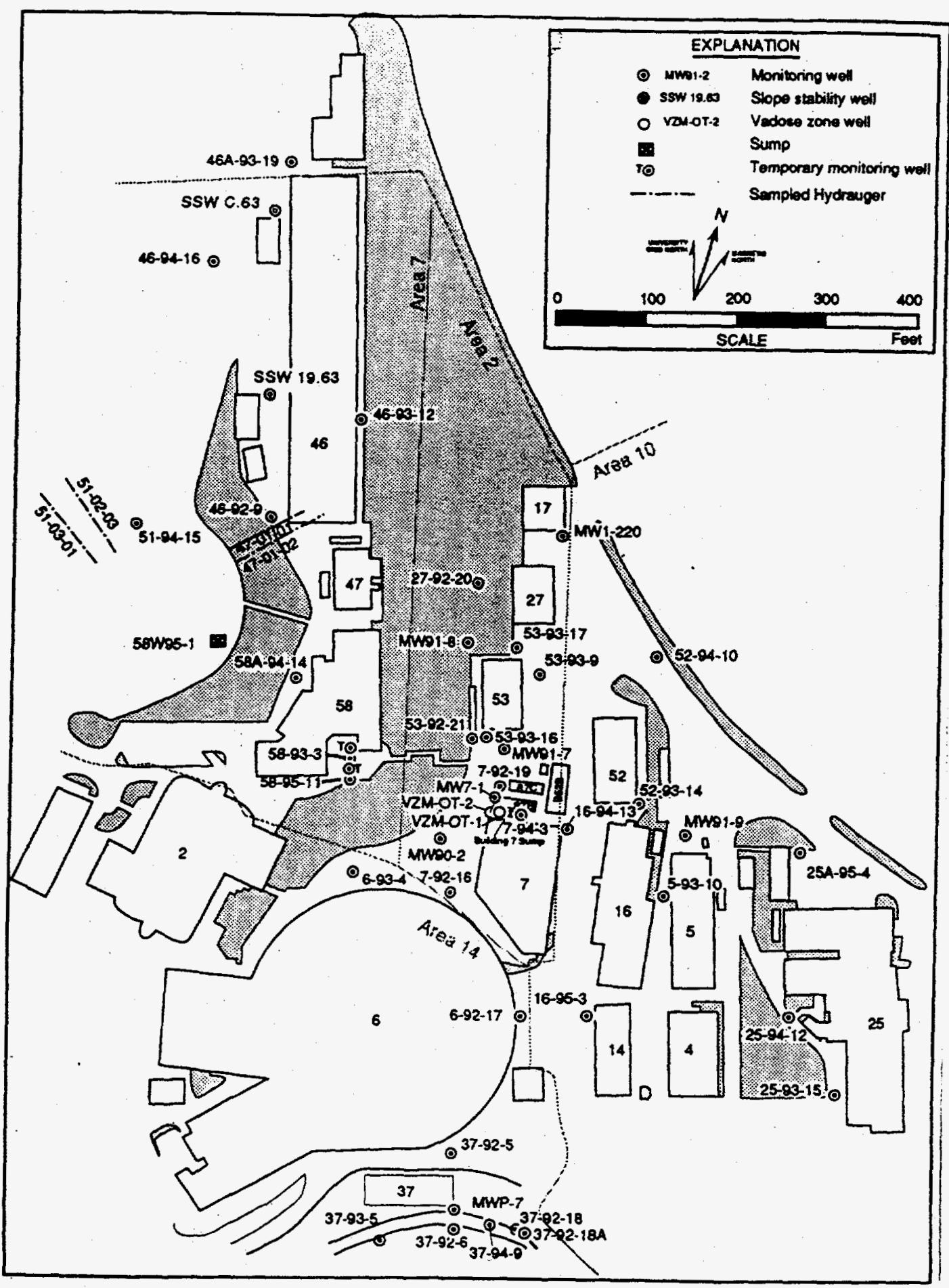

Figure 6. Monitoring well location map of the "Old Town" area at LBNL. Modified from LBNL (1994). 
in July 1995, total VoCs were found at over $300,000 \mathrm{ppb}$, of which $190,000 \mathrm{ppb}$ were PCE. Based on this data, the ERP determined that non-aqueous phase liquid (NAPL) was present in the well. This led to additional soil borings in August of 1995 and removal of the sump and surrounding highly contaminated soil (LBNL, 1996). Figure 7 shows the extent of total VoCs in ground water resulting from the "old Town" sump.

\section{Building 71 Area}

Building 71 is located in Area 1 at the northern boundary of LBNL. Ground water pollution was first detected here in 1986 when PCE was found in a hydrauger discharge. Since then, several ground water monitoring wells have been installed to determine the extent of vocs (Figure 8 ).

As a result of sampling these wells, two distinct plumes have been identified. The northern plume consists mostly of Freon 113 (up to $9.00 \mathrm{ppb}$ in 1995) and is centered around the southwest section of Building 71 (well 71-93-2). The plume extends downgradient (westward) as indicated by a well (71-94-1) about 100 feet west of well 71-93-2. However, the western end of the plume has not yet been defined since the western-most well contains several hundred ppb of Freon 113. The eastern end of the plume is defined by well 71-95-8 where Freon 113 has not been detected.

The southern plume occupies the southeastern portion of Area 1 , and consists of mostly PCE. Total VOCs have been detected as high as $112 \mathrm{ppb}$ in hydrauger discharges in this area and $95 \mathrm{ppb}$ in a well screened in the plume (90-3). The plume seems to extend southwest about 250 feet from the area of building 71-H, to well 51B-93-18A near building 64 in area 9. Total VoCs in this well in June 1995 were about $16 \mathrm{ppb}$ most of which was TCE. 


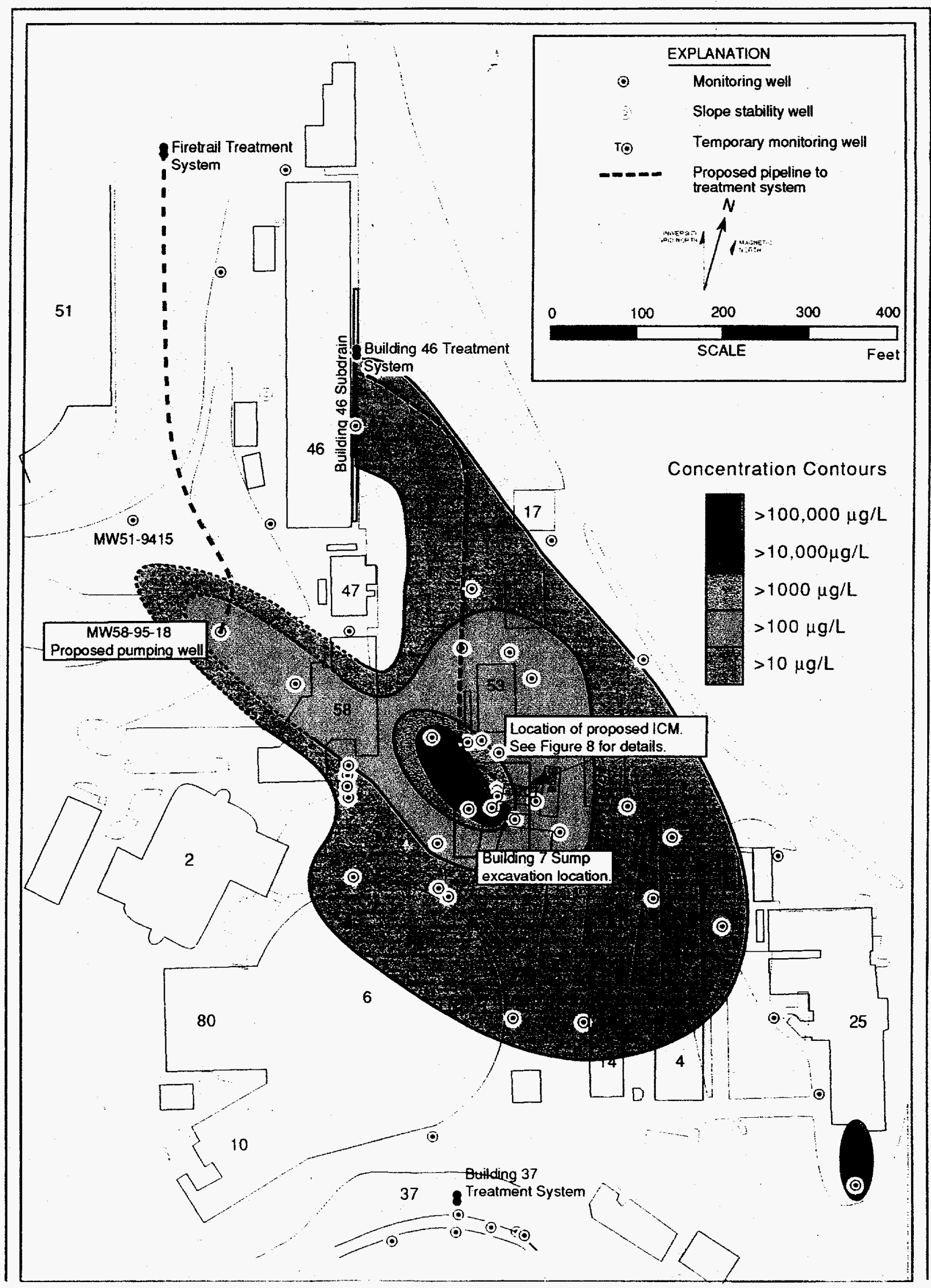

Eigure 7. Concentration (in opb) contour mar of total halogenateri

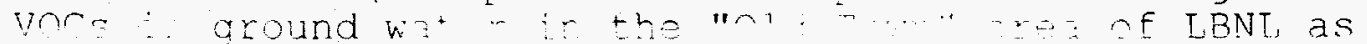
mber 199 ! 


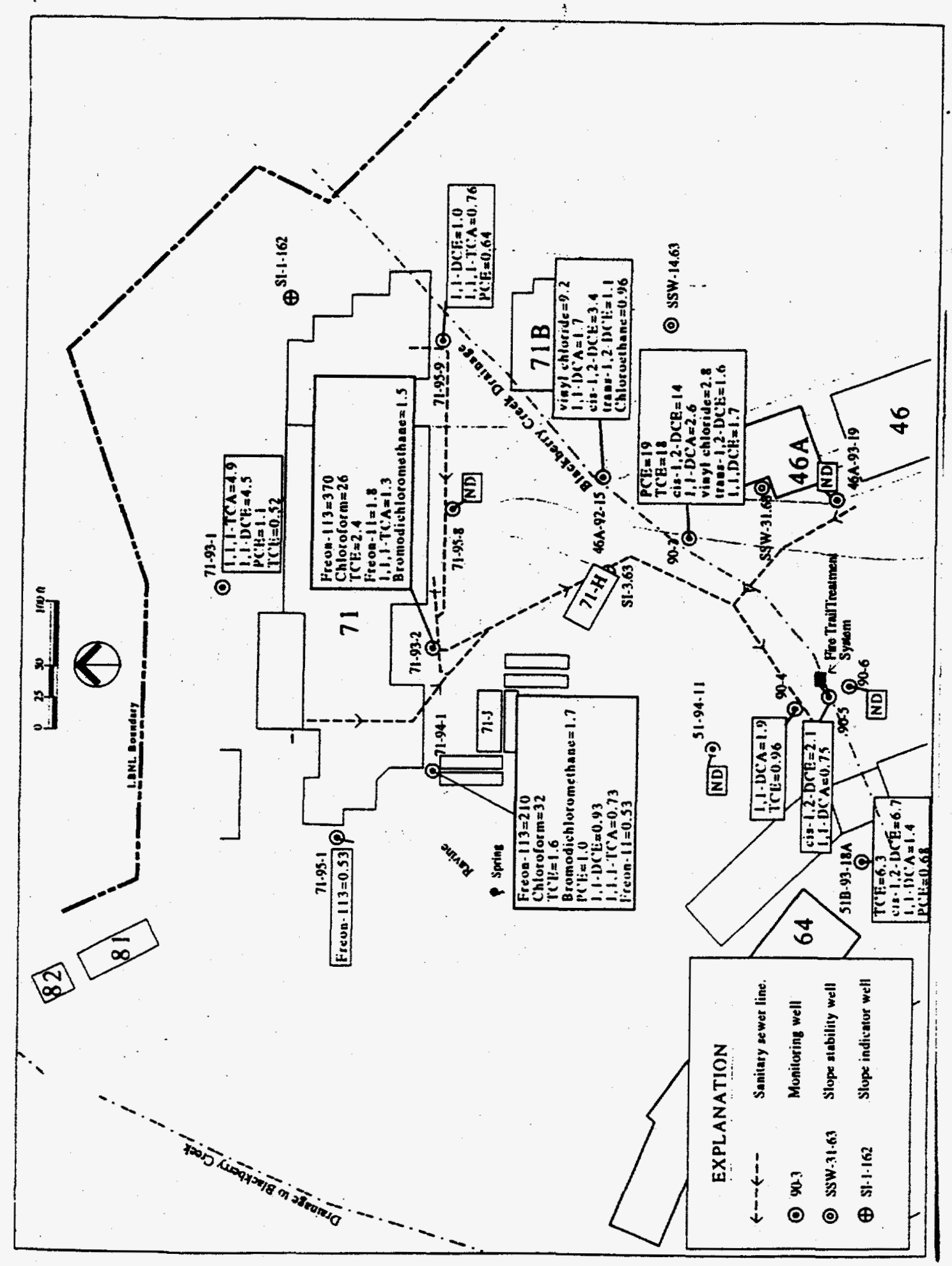

Figure 8. Monitoring well location map, and VOC concentrations (in ppb) as of September 1995, in the Building 71 Area. Modified from LBNL (1995). 
There are low levels of VOCs (less than $15 \mathrm{ppb}$ total VoCs) in wells upgradient from Building $71-\mathrm{H}$, however they contain a different suite of chemicals (mostly TCE and PCE degradation products -- vinyl chloride, and cis-1,2-DCE). These plumes generally follow the Blackberry Creek drainage.

There are several potential sources for the above releases. These include: the linear accelerator cooling unit, the Freon 113 storage tank, and the hazardous materials storage area where 55 gallon drums containing solvents were stored. Only small releases of Freon 113 have been reported (to Iraj Javendel by personal communication) at the cooling unit, and these were cleaned up quickly. There were frequent minor spills of solvents onto the floor when they were dispensed from the drums in the hazardous waste storage area (LBNL, 1992). No releases have been reported from the Freon 113 above ground storage tank.

Discharge from Area 1 hydraugers is collected and sent through a carbon treatment system located at the southwest corner of Area 1.

\section{Tritium in Area 3}

The National Tritium Labeling Facility (NTLF) is housed within Building 75 in Area 3, and has been in operation since 1982. The facility uses tritium as a labeling agent for chemical and biomedical research. Waste tritium from the manufacturing and labeling process is passed through silica gel cartridges in the form of tritiated water. Any remaining tritium is vented into the atmosphere via a 50 foot stack. In 1988, about 500 Curies of tritium were released from the stack. However, since then, these annual releases have been reduced to about 75 curies (LBNL, 1992). 
Tritium was initially detected at $2,000 \mathrm{pCi} / 1$ in a ground water sample from a hydrauger in 1986. Subsequent ground water samples taken from slope stability wells in the area indicated 2,600 $\mathrm{pCi} / 1$ (1988) and $31,000 \mathrm{pCi} / 1$ (1991). Since the slope stability wells were not constructed as environmental wells, additional properly constructed monitoring wells were installed for annual sampling for tritium. Figure 9 shows the location of all the wells in Area 3 and the distribution of tritium in ground water, as of June 1995. Samples from properly constructed monitoring wells are generally much lower in tritium than in the slope stability wells.

\section{Metals}

Initially the LBNL samples all new monitoring wells for metals. Annual monitoring for metals is then conducted at a well if: 1) elevated concentrations (greater than $1 / 2$ of the MCLs) of metals are found, 2) the chemical use history of a solid Waste Management Unit (SWMU) indicates metals may be present, or 3) elevated concentrations of metals are found in the overlying soil. To date, metals concentrations above the respective MCL have only been confirmed (by duplicate sampling) for arsenic at $120 \mathrm{ppb}(\mathrm{MCL}=50 \mathrm{ppb}) \mathrm{C}^{-\lambda}$ mium at $6 \mathrm{ppb}$ (MCL $=5 \mathrm{ppb}$ ), and antimony at $11 \mathrm{ppb}(\mathrm{MCL}=6 \mathrm{ppb})$ in areas 4,7 , and 14 .

\section{Perimeter and off-site Wells}

In order to monitor potential migration of pollutants off-site, LBNL has installed 10 monitoring wells at the downgradient perimeter (south through west) of the site (designated MWP1,P2,P3 etc. (Figure 10)) and 1 well off site. Except for MWP-7 which contains TCE (slightly above the MCL), no vOCs have been confirmed in any of the other perimeter wells throughout quarterly sampling. Off-site well CD-92-28 is located about 1000 


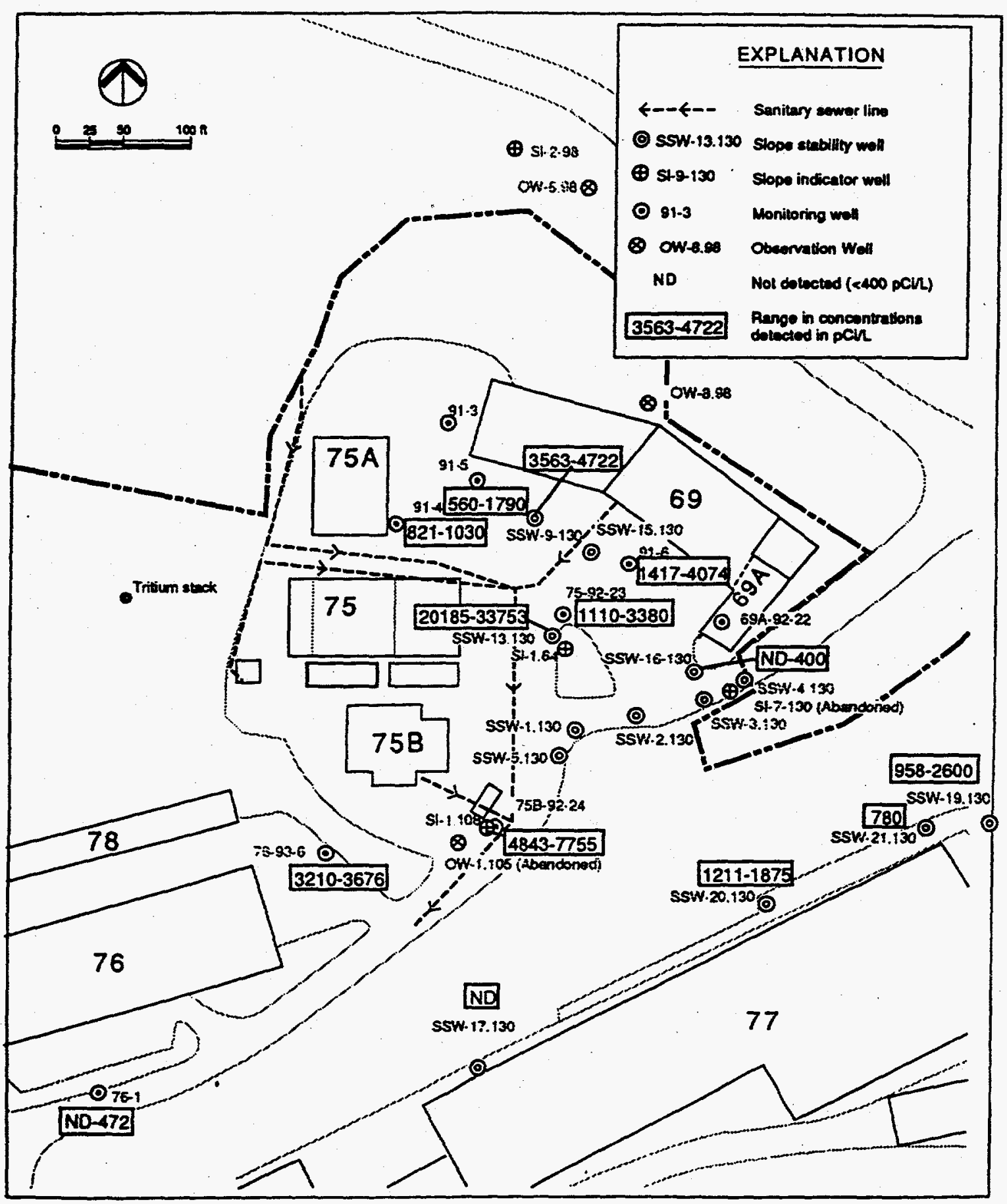

Figure 9. Monitoring well and slope stability well location map, and concentration of tritium (in pCi/l) from July 1994 to June 30, 1995, around the National Tritium Labeling Facility in Area 3. Modified from LBNL (1995). 


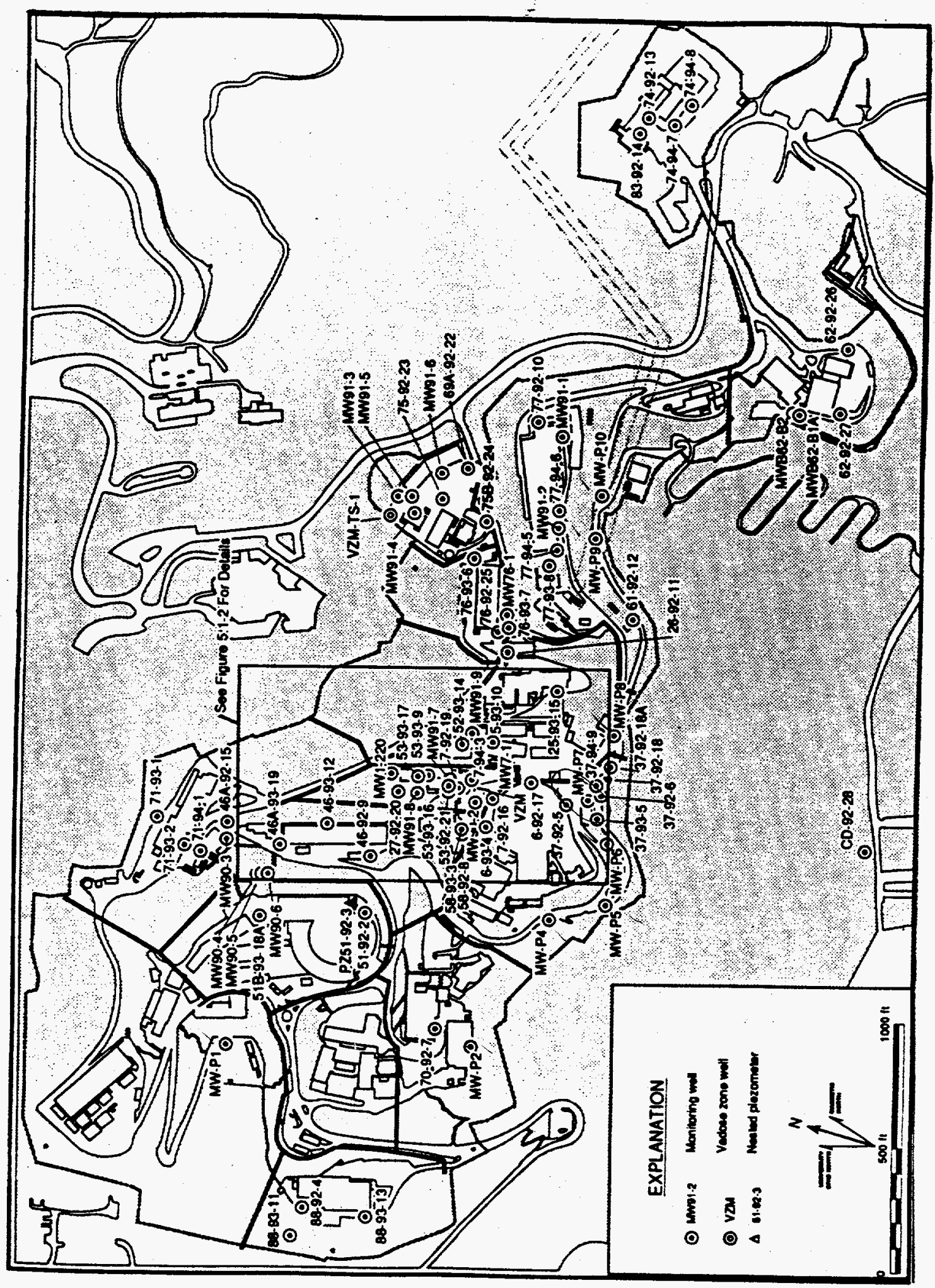

Figure 10. Monitoring well location map for LBNL. Perimeter wells are designated MWP-1, 2, etc. Modified from LBNL (1994).

STATE WATER RESOURCES CONTROL BOARD 95 AIP FINAL SUMMARY REPORT 
feet sou of Building 37 on Centennial Drive. No VOCs have been confirme in this well, which also was included in AIP comparison sampling.

Another cif-site well (OW-3-225) was installed by the University of Califoria at Berkeley in 1989 and is located in the Horseshoe Parking Iat southwest of Building 70A. No VoCs have been confime in this off-site well either.

\subsection{DIBZCUSSION AND ANALYSIS}

\section{"OLD TOWN AREA"}

The plum of chlorinated solvents emanating from the Building 7 sump ( $B$ 7 lume) in "Old Town" represents the worst known soil and ground pollution at the site. As such, soil and ground water instigations in this area have been the most extensive. These inestigations have revealed subsurface conditions that directly control pollutant migration pathways in a manner that is unpredictole and very difficult to define. However, through the careful work conducted by the ERP, a general understanding of the problem has been achieved, and feasible remedial actions have been both undertaken and proposed.

The ERP discovered early on in the investigation process that the ground water flow in the "Old Town" area did not follow a subdued replica of the topography as is normally the case. The topography of the Building 7 area is characterized by moderate to steep slopes dipping to the west toward Buildings 2 and 58, and a gentle upward slope to the north. However, ground water elevation data indicated that ground water was flowing to the northwest toward Building 53, essentially in a topographically uphill direction. Not surprisingly, the distribution of pollutant followed this path as the wells adjacent to Building 
53 contained the highest levels of total VoCs (up to $2000 \mathrm{ppb}$ ), until additional wells were installed in 1995.

Based on the hydrogeologic data obtained from the numerous wells installed during early. site investigations, this apparent contradiction was resolved. Figure 11 shows a cross-section (from south to north) of the geology underlying the area between Buildings 7 and 53 and some of the wells and borings that have been installed. This cross-section shows that the Orinda Formation, which has a much lower permeability than the Moraga Formation, is controlling local ground water flow as the direction of the ground water gradient follows the subsurface dip of the orinda Formation. Ground water always follows the path of least resistance and thus preferential flow is through the Moraga formation and around the orinda Formation.

Additional evidence to support this model is found in the distribution of pollutants in two sets of cluster wells, 53-93-16 and 53-93-21, installed adjacent to Building 53. The former consists of two wells screened only in the Moraga Formation, and the latter consists of 4 wells screened only in the orinda Formation. Total VoCs up to $2000 \mathrm{ppb}$ have been found in the Moraga wells, and these vocs are characteristic of the B7 Plume (mostly PCE). However, none of the VOCs from the B7 Plume have been found in the Orinda Wells in this area. Less than 1 ppb of benzene and chloroform (unrelated to the B7 PIume) have been occasionally detected in one of the wells in the orinda cluster. All of the wells in these two clusters were included in AIP comparison sampling (Table 1 ).

Based on a structural contour map of the Orinda Formation (LBNL, 1996), the upper surface has a significant amount of relief and thus the Moraga/Orinda contact varies laterally in depth. Where the contact is shallow (above the water table) 


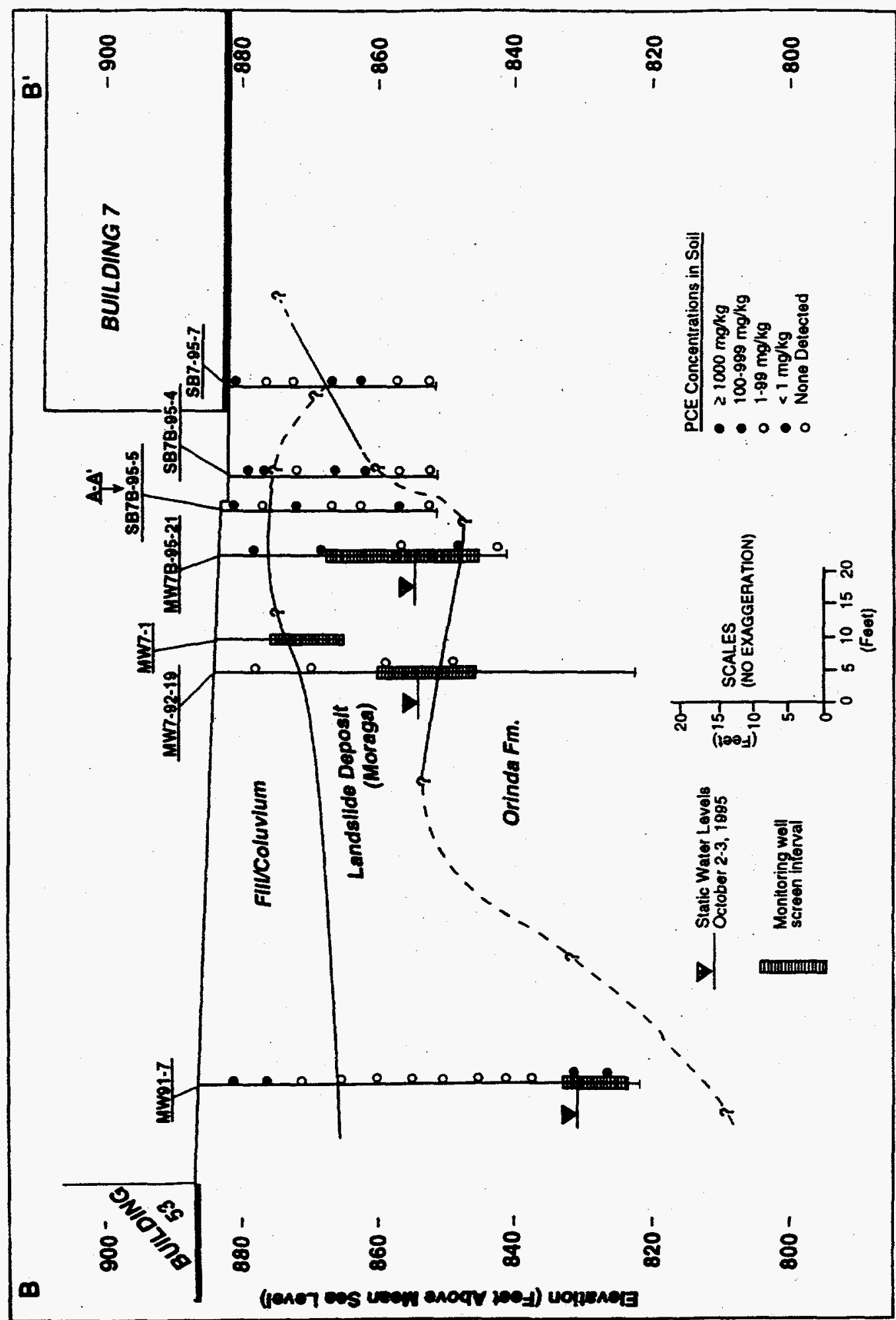

Figure 11. Cross-section (from south to north) of the geology underlying the area between Buildings 7 and 53 . Modified from LBNL (1996). 


\begin{tabular}{|c|c|c|c|c|}
\hline \multirow[t]{2}{*}{ DATE } & \multirow[t]{2}{*}{ WELL } & \multirow[t]{2}{*}{ ANALYTE } & \multicolumn{2}{|c|}{ RESULTS (ppb) DL $*=.5$} \\
\hline & & & LBL & AI? \\
\hline \multirow[t]{18}{*}{$5 / 11 / 95$} & \multirow[t]{4}{*}{$53-93-16 \quad(42)$} & cis $1,2-$ dce & 8.9 & 6.6 \\
\hline & & pce & 36 & 50.6 \\
\hline & & tce & 11 & 15.7 \\
\hline & & trans 1.2 dce & nd & .8 \\
\hline & \multirow[t]{9}{*}{$53-93-16 \quad(69)$} & carbon tetra & 45 & 25 \\
\hline & & chloroform & 16 & 13.6 \\
\hline & & 1,1 dca & nd & 4.1 \\
\hline & & 1,1 dce & 32 & 23.3 \\
\hline & & cis 1,2-dce & 51 & 36.9 \\
\hline & & trans 1,2 -dce & nd & 6.1 \\
\hline & & pce & 520 & 705 \\
\hline & & $1,1,1-t c a$ & nd & 2.2 \\
\hline & & tce & 210 & 298 \\
\hline & \multirow[t]{2}{*}{$53-92-21 \quad(130)$} & pce & 0.64 & .7 \\
\hline & & tce & nd & .5 \\
\hline & $\begin{array}{c}53-93-21 \\
(147,164) \\
\end{array}$ & vocs & nd & nd \\
\hline & $53-93-21 \quad(193)$ & benzene & nd & .7 \\
\hline & $\mathrm{cd}-92-28$ & vocs & nd & nd \\
\hline \multirow[t]{9}{*}{$6-7-95$} & \multirow[t]{7}{*}{$71-94-1$} & chloroform & 2 & 31.8 \\
\hline & & pce & 1.0 & 1.0 \\
\hline & & toluene & 1.0 & 1.1 \\
\hline & & $1,1,1,-t c a$ & .73 & .7 \\
\hline & & tce & 1.6 & 1.8 \\
\hline & & freon 113 & 210 & $1130 * *$ \\
\hline & & bromodichloro & nd & 2.1 \\
\hline & \multirow[t]{2}{*}{$71-93-1$} & chlfrm & nd & .9 \\
\hline & & 1,1 -dce & 4.5 & 5.4 \\
\hline \multirow[t]{8}{*}{$6-7-95$} & \multirow[t]{4}{*}{$71-93-1$} & pce & 1.0 & 0.7 \\
\hline & & $1,1,1-t c a$ & 4.9 & 5.3 \\
\hline & & tce & .52 & .8 \\
\hline & & benzene & nd & .6 \\
\hline & $\begin{array}{c}\text { tritium spikes } \\
6-95-55\end{array}$ & \multirow[t]{4}{*}{$\begin{array}{l}\text { tritium } \\
(p C i / l)\end{array}$} & $\begin{array}{c}1515+/- \\
256\end{array}$ & $\begin{array}{c}\text { spiked at } \\
2,000\end{array}$ \\
\hline & $6-95-56$ & & $\begin{array}{c}1422+1- \\
253\end{array}$ & $\begin{array}{c}\text { spiked at } \\
2,000\end{array}$ \\
\hline & $6-95-57$ & & nd & no spike \\
\hline & $6-95-58$ & & nd & no spike \\
\hline
\end{tabular}

- DL = Detection Limit

* * Tentative identification by NIST library search with an estimated concentration calculated by using ratio of areas from total ion chromatograms with the internal standard fluorobenzene.

1. LBI used EPA method 8260 , SWRCB used EPA methods $601 / 602$ modified.

2. VOC constituents not listed were not detected.

Table 1. Results of AIP/ERP comparison sampling for VOCs in various wells at LBNL. Tritium spikes are also included. 
ground water flows around the Orinda Formation, and this explains the irregular shape of the B7 Plume (See Figure 7). In the "Old Town" area, the Moraga Formation has slid over the Orinda Formation as the result of a paleo-landslide (LBNL, 1995) The major turning point in developing a feasible plan for remediating the B7 Plume occurred when well MW-7B-95-2I was installed and sampled in July 1995. Total VoCs were found at over 300,000 ppb, of which $190,000 \mathrm{ppb}$ were PCE. Since the solubility of PCE is approximately 150,000 ppb, these results indicated that non-aqueous phase liquid (NAPL) PCE was present.

This led to additional soil borings in August of 1995 and removal of the sump and surrounding highly contaminated soil (LBNL, 1996). However, the excavation could only extend to 17 feet below grade since a deeper excavation would have threatened the structural integrity of nearby buildings and also was beyond the operating limits of the excavation equipment. This resulted in leaving some highly contaminated soil and probably non-aqueous phase solvents in place.

Since this highly contaminated soil, and NAPL, could not be removed and thus would provide a constant source for further pollution of the groind water, the ERP proposed a remedial action plan to contain both the source area and the downgradient boundary of the B7 Plume (LBNL, 1996). Their proposal involves the installation of an extraction trench composed of gravel that is keyed into the upper surface of the Orinda Formation (Figure 12). The trench will form an arc about 25 feet radially from the former sump and contain north through west ground water flow. Since the trench will be keyed into the orinda Formation (Figure 13), this will prevent pollutants from escaping beneath it. 


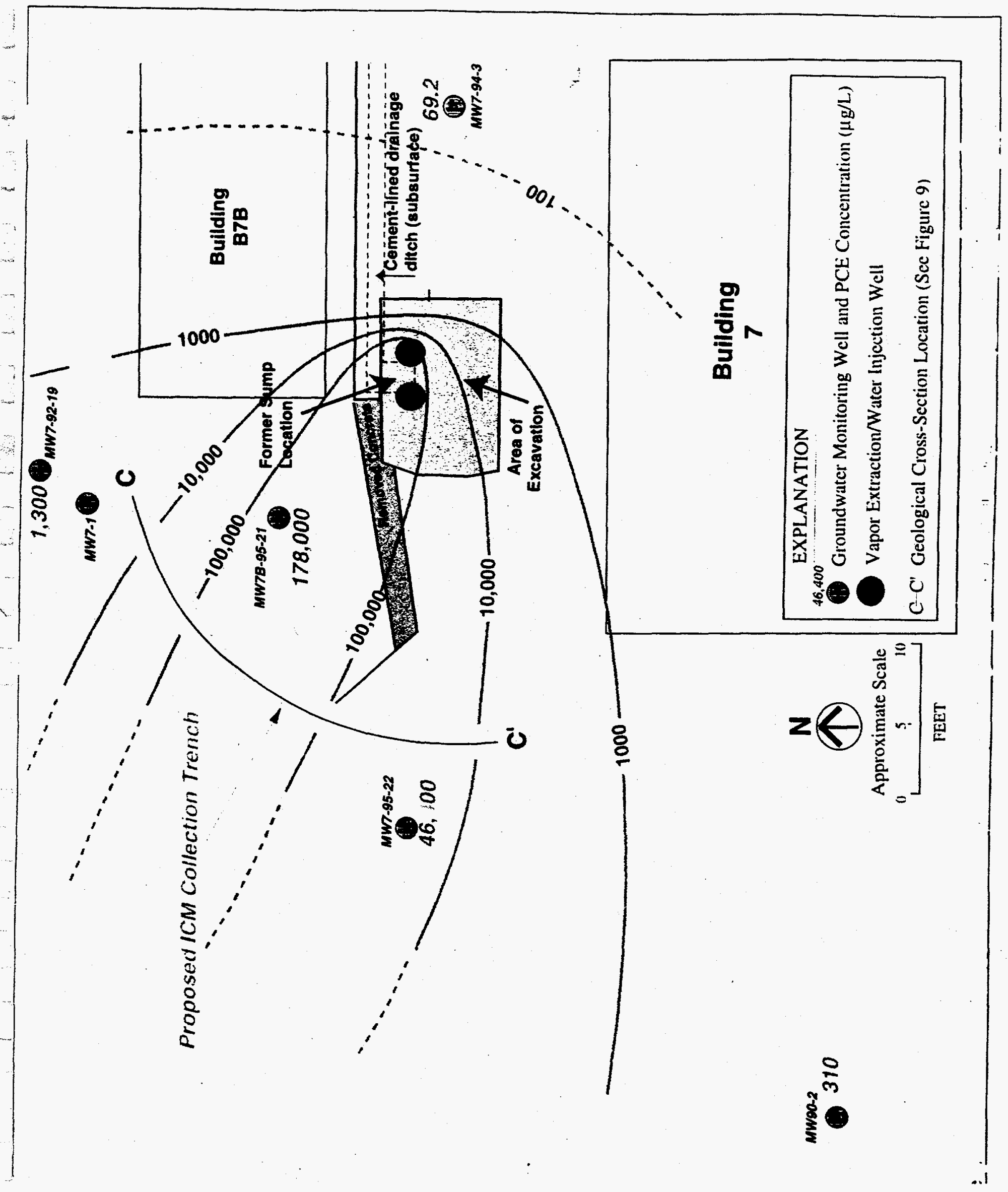

Figure 12. Map view of the proposed ground water collection trench in the "Old Town" Area. Modified from LBNL (1996). 


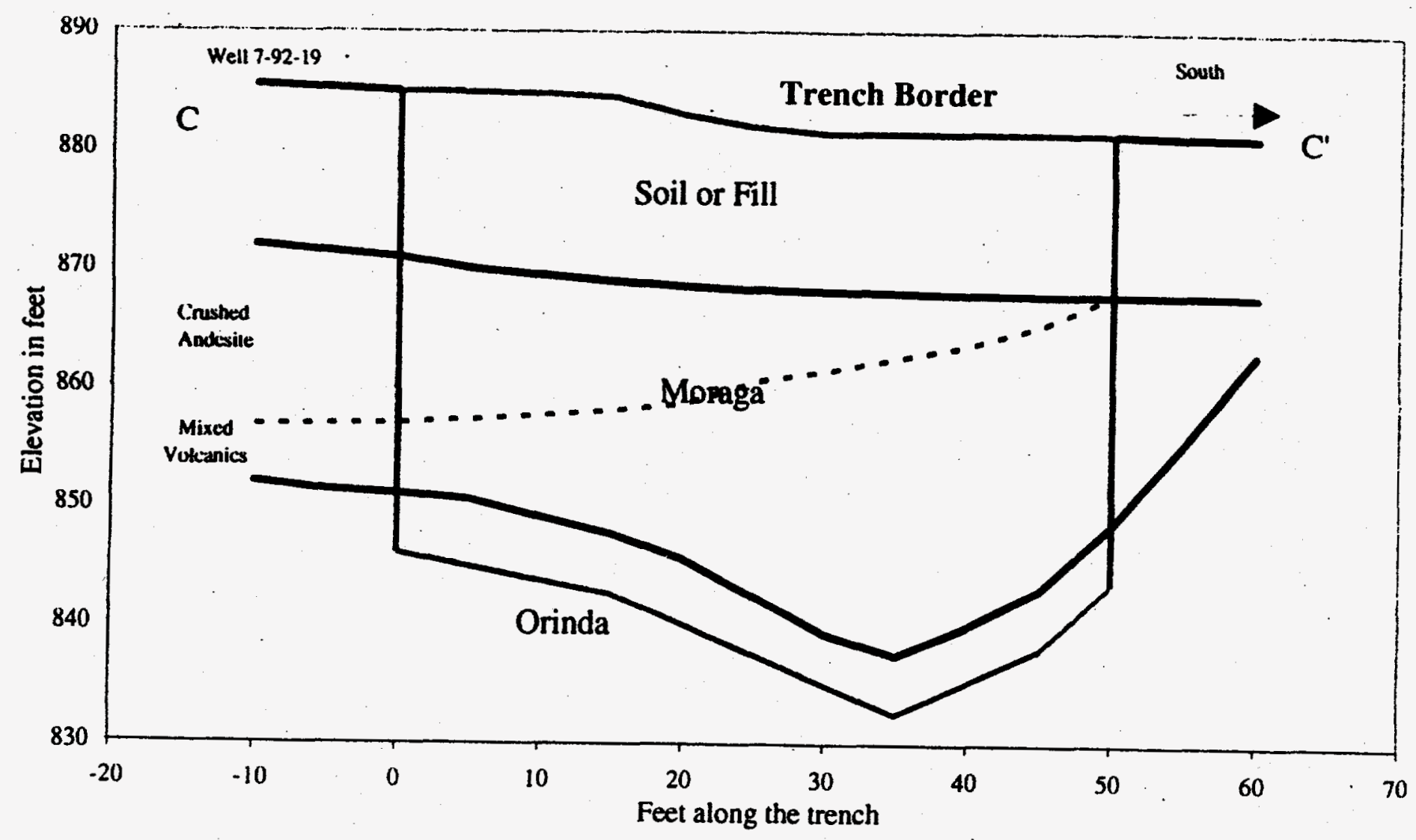

Figure 13. Cross-section of the proposed ground water collection trench in the "Old Town" Area. Note that the trench will be keyed into the low permeability orinda Formation. Modified from LBNL (1996). 
Ground water will be pumped from the trench and piped into the Building 46 treatment system. This remediation system design. should effectively cut off the major portion of the B7 Plume from the source area. Downgradient of the trench, the remaining dissolved ground water pollution can then be contained by the currently operating Building 46 treatment system for the northern lobe of the plume, and a proposed treatment system for the southern lobe (see Figure 7). The proposed system for the southern lobe of the plume will consist of an extraction well located at the northwest end of the southern lobe of the plume (MW58-95-18) and a treatment system about 600 feet north adjacent to Building 51 (Firetrail Treatment system).

\section{BUILDING 71 AREA}

The southern plume of VOCs in the Building 71 area consists mostly of PCE at low to moderate levels ( $<100 \mathrm{ppb})$. This indicates that the source of the pollution in this area is probably surface spills into soils and subsequent leaching into the ground water from rainfall and/or irrigation activities. If leaks had occurred directly into ground water much higher concentrations would likely be found. The most likely sources are the spills that occurred when transferring solvents in the Hazardous Waste Storage Area.

Hydraugers in the area are transporting some of the polluted ground water to the treatment system at the south west corner of Area 1, and this provides at least some active remediation of the low level pollution.

The Freon 113 plume located under and around Building 71 consists of much higher levels of pollution. However, the drinking water maximum contaminant level (MCL) for Freon 113 is $1200 \mathrm{ppb}$, and thus these levels are well under the MCL. The source of the 
Freon 113 in ground water has not yet been determined, although there are several potential sources in the area.

It is not likely that the ground water pollution by Freon 113 was caused by minor surface spills, since this chemical has a very high vapor pressure and would have volatilized almost instantly upon exposure to the ambient atmosphere. However, a significant surface spill may have allowed enough Freon 113 to escape into the ground and then into ground water. The concentration of Freon 113 has been steadily decreasing since investigations began in this area in 1993.

The western end of the Freon 113 plume has not yet been defined. However, since the concentration of Freon 113 is far below the MCL, and levels have been steadily decreasing, we do not recommend further investigations to the west and active remediation unless further monitoring shows a change in this trend.

NATIONAL TRITIUM LABELING FACILITY

Tritium in ground water at LBNL is localized around the NTLF. Clearly the source $c^{f}$ the tritium is the allowed emission of tritiated water vapor from the NTLF stack. On foggy or rainy days this vapor falls to the ground and enters ground water either through slope stability. wells or the vadose zone. The highest concentrations have been found in or near the slope stability wells since they provided a conduit for the tritium to easily enter ground water. The upper $5 \mathrm{ft}$ of the annulus of the slope stability wells with the highest concentrations of tritium have been sealed (Javendel, Personal Communication).

Even without the slope stability wells, tritium may still enter the ground water through the vadose zone. As long as tritiated 
vapor is emitted from the stack, ground water will continue to contain tritium at low concentrations (below MCL). However, SWWRB staff do not find that this is a problem since:

1. The levels of tritium are well below the MCL;

2. The ground water at LBNL is not currently or reasonably anticipated to be used, and,

3. Ground water flow at this area of LBNL is very slow. Thus, by the time tritiated ground water could reach site boundaries the tritium will have completely decayed due to its short half-life ( 12.5 years).

\subsection{SUMMARY, CONCLUSION, AND RECOMMENDATIONS}

Under the ERP, extensive site investigations have been conducted at LBNL to identify and remediate releases of hazardous chemicals and radionuclides at the facility. The ERP has utilized nearly every investigative tool currently available including site records research, soil gas sampling, soil borings and soil sampling, installation of monitoring wells, aquifer testing, tracer tests, stable isotone sampling, geophysical surveys, and thorough computer analysis of the data. The data has been presented in a very organized and understandable format and virtually all activities have been thoroughly documented.

The results of these investigations show that the soil and ground water pollution at the site consists primarily of chlorinated hydrocarbons. Low levels of tritium have also been found. The three main areas of ground water pollution at the site are in the "Old Town" area, the Building 71 area, and near the National Tritium Labeling Facility. 
The most intensive site investigations have been conducted in the "Old Town" area where a sump was used to dispose of waste solvents. The sump has been removed along with highly contaminated soil but residual highly-contaminated soil and ground water still remain. Through the installation of several monitoring wells, the extent of ground water pollution has essentially been defined. Site investigations have shown the ground water flow in the area is controlled by the geology, specifically by the low permeability Orinda Formation. This rock unit has directed ground water flow and dissolved vocs to the northwest toward Building 53 and has split the plume into two lobes (north and south) that form around Building 47 .

A ground water treatment facility is currently in place to contain the northern lobe at Building 46. A proposed treatment system consisting of an arc shaped trench keyed into the orinda Formation that will contain the highly contaminated water near the source area (sump) and cut the bulk of the plume off from its source. Highly contaminated ground water will then be pumped from the trench and piped to the Building 46 treatment system for remediation. Another proposed treatment system will contain the southern lobe also via ground water pump and treat. The extraction well for this system is located northwest of Building 58. We recommend that the proposed treatment systems be implemented and performance monitored.

Ground water pollution near Building 71 in Area 1 consists of two distinct plumes. The northern plume consist of mostly Freon 113 and is centered around the southern portion of Building 71 . Up to $900 \mathrm{ppb}$ (MCL = $1200 \mathrm{ppb}$ ) of Freon 113 have been detected in this plume, but levels have been steadily decreasing since quarterly sampling began. The plume extends down-gradient to the west at least 100 feet and the western boundary of the plume has not been defined. 
However, since the concentration of Freon 113 is far below the MCL, and levels have been steadily decreasing, SWRCB staff do not find it necessary to conduct further investigations to the west nor to actively contain and/or remediate the plume. We recommend that LBNL maintain its current monitoring schedule for the wells in this area and re-evaluate the problem if the trend in monitoring data changes.

The southern plume consists of low levels of VOCs (mostly PCE) that probably entered ground water by leaching of soils in the Hazardous Waste Storage Area. The plume extends approximately 300 feet to the southwest into Area 9 near Building 64 . The extent of the plume has essentially been defined. Hydraugers in the area carry some of the polluted ground water to a carbon treatment system located in the southwest corner of Area 1 .

The SWRCB staff do not recommend further site investigations of the southern plume, however, LBNL should maintain its current monitoring schedule of the wells screened in this plume.

Low levels of tritium (less than the MCL) are localized in ground water near the NTLF. The source of this tritium is the allowed emission of tritiated water vapor from the NTLF stack. As long as emissions of tritiated water vapor from the stack are allowed, low level of tritium will also be found in the nearby ground water. However, we find that this is not a problem since tritium levels are less than the MCL, the ground water at LBNL is not currently or anticipated to be used, and ground water flow is slow enough to allow for decay of the tritium before it reaches site boundaries.

Perimeter wells have been installed along the downgradient (south through west) boundary of LBNL and, except for well MWP-7 which contains TCE slightly above the MCL, no voCs have been confirmed 
in these wells. Ground water from MWP-7 is being pumped and treated to prohibit further migration of pollutants. Two offsite wells that are included in quarterly sampling for vocs have also not contained confirmed voCs.

Comparison sampling for VOCs conducted by the AIP has shown no discrepancies between ERP and AIP results. 


\subsection{REFERENCES}

Lawrence Berkeley National Laboratory, September 1992, RCRA Facility Assessment at the Lawrence National Laboratory. Lawrence Berkeley Laboratory Environmental Restoration Program.

, October 1994, LBNL Environmental Restoration Program Quarterly Review Meeting. Iraj Javandel. Lawrence Berkeley National Laboratory.

November 1994, RCRA Facility Investigation. Phase I. Progress Report. Lawrence Berkeley Laboratory Environmental Restoration Program.

February 1995, LBNL Environmental Restoration Program Quarterly Review Meeting. Iraj Javandel. Lawrence Berkeley National Laboratory.

, April 1995, LBNL Environmental Restoration Program Quarterly Review Meeting. Iraj Javandel. Lawrence Berkeley National Laboratory.

July 1995, LBNL Environmental Restoration Program Quarterly Review Meeting. Iraj Javandel. Lawrence Berkeley National Laboratory.

- October 1995, LBNL Environmental Restoration Program Quarterly Review Meeting. Iraj Javandel. Lawrence Berkeley National Laboratory.

November 1995, RCRA Facility Investigation. Phase II. Progress Report. Lawrence Berkeley Laboratory Environmental Restoration Program.

January 1996, Environmental Restoration Program Interim Correction Measures (ICM) Workplan for the old Town Ground water Plume, A Joint Effort of Environment, Health and Safety Division and Earth Sciences Division, Lawrence Berkeley National Laboratory. 


\title{
State Water Resources Control Board 1995 AIP Summary Report
}

\section{STANFORD LINEAR ACCELERATOR CENTER}

\author{
Prepared For: \\ UNITED STATES DEPARTMENT OF ENERGY \\ OAKLAND OPERATIONS
}

Prepared By:

CHUCK NESMITH

ASSOCIATE ENGINEERING GEOLOGIST STATE WATER RESOURCES CONTROL BOARD

DIVISION OF CLEAN WATER PROGRAMS SACRAMENTO， CALIFORNIA

MARCH 1996 


\subsection{STANFORD LINEAR ACCELERATOR CENTER}

\subsection{EXECUTIVE SUMMARY}

The State Water Resources Control Board's (SWRCB) staff has evaluated the adequacy of the environmental ground water monitoring program at stanford Linear Accelerator Center (SLAC) as mandated by the California Agreement in Principle (AIP) with the U.S. Department of Energy (DOE). This evaluation included review of available literature on environmental monitoring at SLAC, as well as computer analysis of the collected data.

Additionally, SWRCB staff conducted comparison ground water sampling in order to evaluate adequate quality control for ground water sampling at SLAC, and also conducted an aquifer test on February 2, 1996 as described in Appendix 6.0A of this report.

The SWRCB staff finds that volatile organic compounds (VOCs) have leaked into ground water at SLAC in four different areas: 1) the leaking underground waste solvent tank (UST) area, 2) the plating shop area, 3) the hazardous waste disposal area, and 4) the end beam area. Ground water impacts by VoCs range from very high levels (possibly non-aqueous phase liquids) to very low levels (less than $50 \mathrm{ppb}$ ). Nineteen wells have been installed to investigate these leaks: one well was abandoned in 1986. Additional well(s) will be needed to fully investigate the extent of the voc plumes and identify their source(s).

Although SLAC has sampled for metals in ground water, the initial sampling effort provided meaningless data since sampling personnel did not filter samples prior to preserving them in acid. Consequently, the results were highly variable from quarter to quarter and indicated very high values for hazardous metals in ground water. According to the SLAC staff, subsequent sampling for metals after 1993 followed accepted procedures for 
dissolved metals and samples were filtered prior to preservation. However, SWRCB staff has not been provided with this data as it was not included in the 1994 annual environmental monitoring report for SLAC. This data should be evaluated and a determination made as to whether hazardous metals have also leaked into ground water at SLAC.

Low levels of tritium (less than $15,000 \mathrm{pCi} / 1$ ) have been found in one well at SLAC, located on the eastern end of the LINAC. The maximum contaminant level for tritium in drinking water is 20,000 pCi/L. SLAC staff attributes the presence of tritium in ground water to be the result of either activation by the accelerator beam, or leaks from water lines. SLAC will continue to monitor the well for tritium and will conduct further investigations if tritium levels develop a rising trend. SWRCB staff concurs with this approach.

There are two domestic water supply wells within one mile of SLAC in the cross-gradient ground water direction. There is little information on these wells, however, they are probably screened deep within the same Tertiary bedrock as the environmental monitoring wells at SLAC. It is highly unlikely that leaks from SLAC will reach these wells since ground water flow rates in the Tertiary bedrock are very low, and the LINAC intercepts shallow ground water southeast of the major leaks at the site. This may not be the case if the pollutants have migrated to deep ground water and have flowed underneath the IINAC.

Further site investigations should be conducted to ensure that pollutants have not migrated to deep ground water. Additionally, measures should be taken to contain polluted ground water and keep it from flowing off-site. 


\subsection{INTRODUCTION}

GENERAL

The Stanford Linear Accelerator Center (SLAC) is a Department of Energy (DOE) Facility located near Stanford University in Palo Alto, California (Figure 1). The facility is best known for its research in elementary particle physics using accelerated electron beams via its two mile long linear accelerator.

Ground water investigations began with the installation of nine monitoring wells after the 1983 discovery of a leaking underground storage tank (UST) that contained solvents. In response to the leak, the Regional Water Quality Control Board (San Francisco Bay Region) issued Cleanup and Abatement order 85-88. The U.S. EPA also became involved at SLAC due to the tank leak, and subsequently, identified it as a potential hazardous waste site and entered SLAC into the Comprehensive Environmental Response, Compensation, and Liability Information System (CERCLIS).

Site-wide investigations aimed at identifying all areas of potential pollution began under DOE Order 5400.4 in 1990. This order directed SLAC to follow the provisions of CERCLA in performing environmental restoration. As such, SLAC has prepared a Remedial Investigation/Feasibility study workplan and will conduct activities accordingly.

Site-wide investigations conducted to date have included the installation of 10 more monitoring wells at major areas of the facility that historically, and/or presently store, handle, or use chemicals which may pose a threat to ground water quality, and to monitor general ground water quality (Figure 2). A total of 21 monitoring wells are currently in use at SLAC, three of 


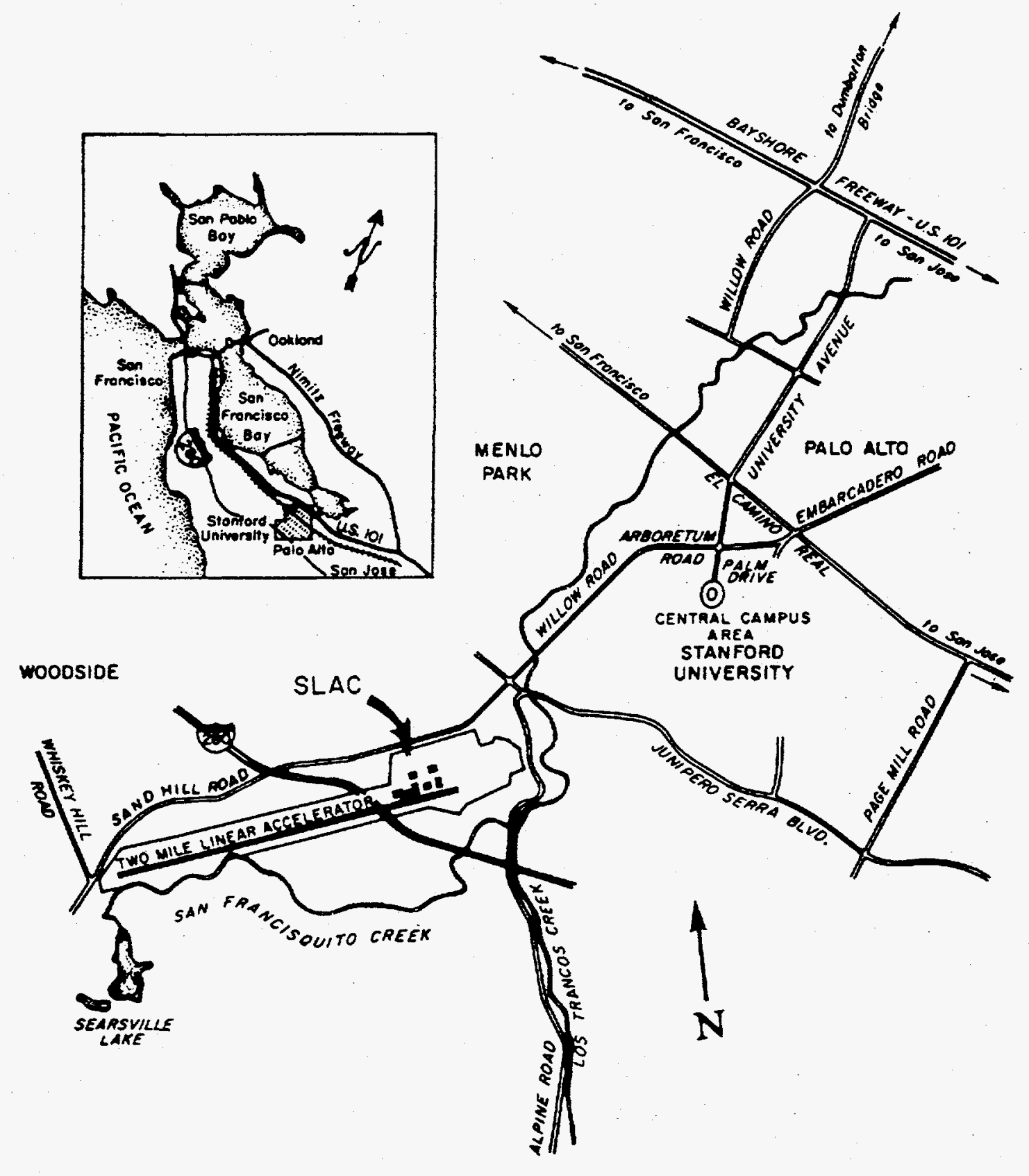

Figure 1. Location map for the stanford Iinear Accelerator Center (SIAC). Modified from SLAC (1994). 


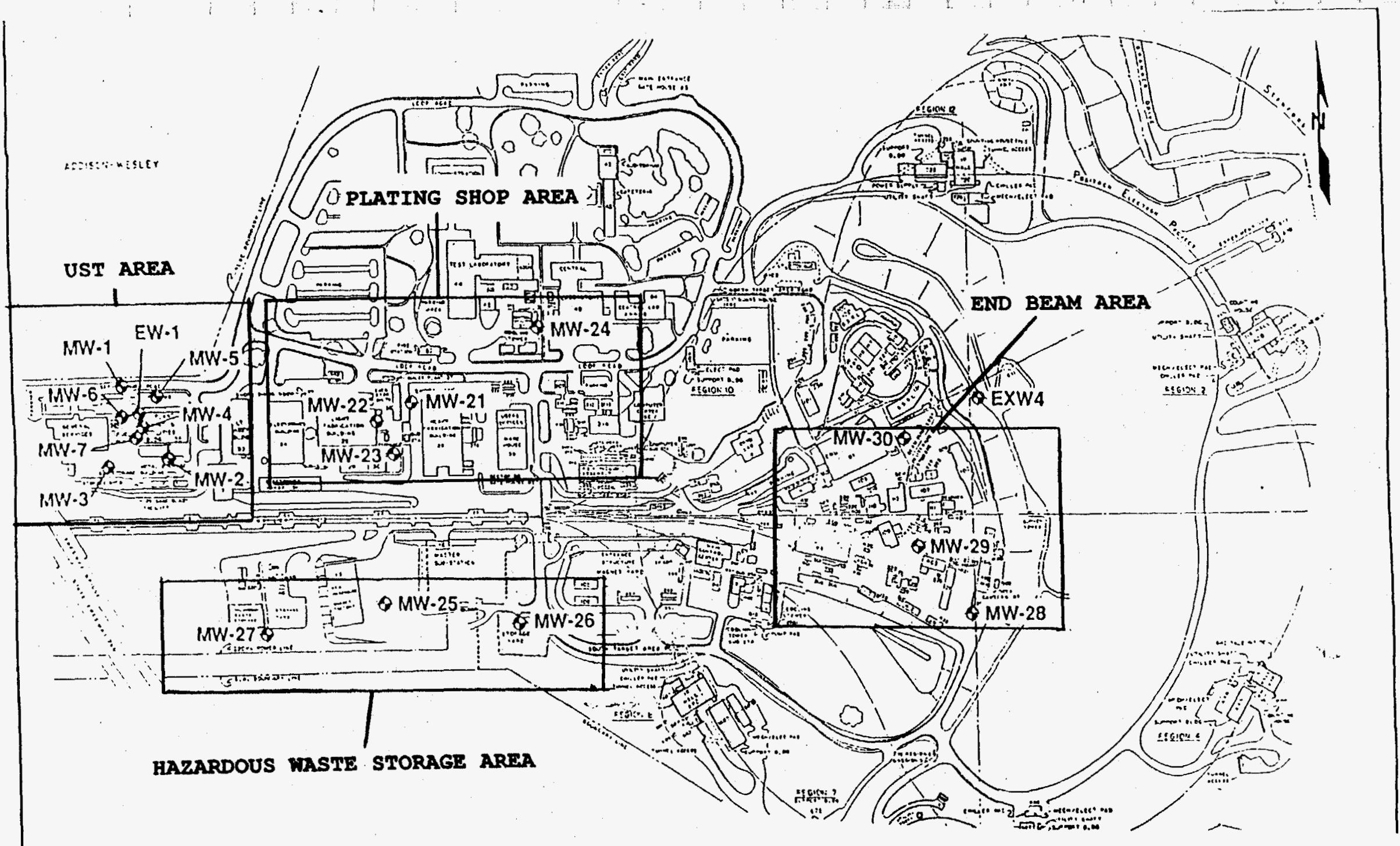

EXPLANATION

INW.28 \& Moniloring Well

O $500 \mathrm{ft}$. STATE WATER RESOURCES CONTROL BOARD

E-003 Surlace Sampling Point

Figure 2.

Site map showing the location of ground water monitoring wells that are used for environmental monitoring. The site is divided into four different areas for the purpose of describing investigation activities at SLAC. Modified from SLAC (1993) 
these were installed during initial construction of the facility.

\section{PURPOSE AND SCOPE}

The purpose of this report is to provide a detailed evaluation of the adequacy of the environmental ground water monitoring system at SLAC. Three basic factors were considered in this evaluation:

1. Nature and extent of any known spill, leak, or waste disposal activity etc.

2. Regional and local hydrogeologic conceptual model developed by SWRCB staff. This includes evaluation of ground water movement, recharge and discharge, and the geologic factors which affect them.

3. Location and construction of monitoring wells.

This evaluation is based on available data collected at SLAC by various entities over the past 12 years. These data have been collected under multiple regulatory and non-regulatory programs, including California Water Code Section 13267, the Resource Conservation and Recovery Act (RCRA), and the AIP. Additionally, geotechnical data gathered prior to, and during, construction of the LINAC (early to mid 1960s) were also used.

SWRCB staff have also analyzed selected ground water data via two computer programs, Surfer and Quattro Pro. Surfer is a contouring program, which can also display the contoured data as a three-dimensional surface. Quattro Pro presents data in multiple graphic forms. Pertinent contour maps, surface maps, and graphs which illustrate trends or the relationship of data, are presented herein. 
SWRCB staff were unable to obtain elements of the available data set at SLAC that would have helped in preparing this report. These data include: 1) the initial tank removal report (some aspects were in the record) for the leaking underground waste solvent tank (area 1), 2) stable isotope data collected from ground water monitoring wells, and 3 ) documentation on the installation of monitoring wells EM-1 (in 1984), and EW-1 (in 1986), and on the subsequent removal of EM-1 (in 1986).

\subsection{BACKGROUND}

\section{SITE GEOLOGY}

The Stanford Linear Accelerator (SLAC) is located within the San Francisquito Creek basin, in the rolling foothills between the Santa Cruz Mountains and the San Francisco Bay. San Francisquito Creek lies south of the facility, about 500 feet from the linear accelerator at station $40^{1}$ and about 4000 feet south of the accelerator at station 80. Drainage from the facility flows generally southward into San Francisquito Creek and then eastward into San Francisco Bay.

In the area of SLAC, San Francisquito Basin is mostly underlain by Eocene and Miocene marine sandstones, siltstones, and claystones. These rocks were formed from continental rocks which were weathered and eventually washed into the sea. After consolidation, the rocks were uplifted and eroded to form the rolling hills that characterize site topography. Eocene/Miocene rocks range in age from 22 to 47 million years.

\footnotetext{
${ }^{1}$ Station numbers are designated according to their distance, in hundreds of feet, from the west end of the LINAC, i.e., station 40 is $40 \times 100$ (4,000 feet) from the west end of the LINAC.
} 
During and after uplift, the Eocene/Miocene rocks were extensively folded into a sequence of northwest oriented troughs (synclines) and arches (anticlines), and faulted along a generally northwest orientation. Several faults intersect the linear accelerator area. The facility is located approximately two miles east of the San Andreas Fault zone.

From station 00 on the western end of the accelerator, to station 50, the site is underlain by Eocene rocks. At station.50, Miocene rocks have been juxtaposed onto Eocene, most likely by a major fault. Between stations 75 and 90 Eocene rocks appear again as the core of a major anticline, with the limbs of the anticline composed of Miocene rocks.

These Eocene rocks are distinguished from other Eocene rocks exposed at SLAC by the chaotic assemblage of large blocks of older rock that apparently tumbled into the sediments before the sediments had solidified. This was most likely due to submarine landslide activity. Chaotic Eocene rocks also outcrop between stations 00 and 20. Miocene rocks underlie most of the site east of station 90 .

Exposures of younger (Plio-Pleistocene) continental stream/terrace deposits (Santa Clara Formation) occur sporadically at SLAC. Recent (Holocene) stream sediments are exposed along San Francisquito Creek.

HYDROGEOLOGIC CONCEPTUAL MODEL

Ground water at SLAC occurs in at least three different hydrogeologic units:

1. Fractured Eocene/Miocene bedrock. This is where most of the ground water at SLAC occurs, and virtually all of the known 
pollution from VOCs and tritium is found within bedrock. As determined by slug tests, the hydraulic conductivity of this unit is relatively low (on average about $10 \mathrm{e}-5 \mathrm{~cm} / \mathrm{sec}$ ) and ground water flow is mostly controlled by fractures, bedding planes, and other anisotropies in the rock.

Because of this, ground water flow in the unit is complex and does not flow perpendicular to ground water contours. Typically the water table occurs at about 10 to 15 feet below grade in bedrock at SLAC.

2. Santa Clara Formation. The Plio-Pleistocene Santa Clara Formation consists of stream deposits of well-cemented to loose gravel, sand, silt and clay. The only water bearing unit of the santa Clara Formation at SLAC occurs in the eastern-most portion of the site, where it unconformably overlies Tertiary bedrock. No monitoring wells at SLAC are installed in this unit. The estimated formation hydraulic conductivity is about $2 \times 10 \mathrm{e}-5 \mathrm{~cm} / \mathrm{sec}$ (based on one packer test), similar to that of the Tertiary bedrock. The water table in this unit also occurs at about 15 feet below grade.

3. Quaternary stream Deposits. These recent stream sediments occur along the flanks of San Francisquito Creek, and in some areas have been incised by the creek. Because they consist of unconsolidated gravels, sands, silts, and clays, the sediments have a relatively high porosity and hydraulic conductivity (compared to Tertiary bedrock). Measured hydraulic conductivity of these rocks (via a pumping test) is about $6 \times 10 \mathrm{e}-2 \mathrm{~cm} / \mathrm{sec}$. Ground water in these sediments occurs about 6 to 8 feet below grade.

There is very little, if any, interconnection of the ground water in the Tertiary bedrock and the recent stream sediments 
(SLAC 94). This is because the surficial alluvium is relatively thin (less than 10 feet thick), and the water table is typically below the bedrock/alluvium contact.

Ground water recharge of the Tertiary bedrock from rainfall is estimated to be only about $10 \%$ of total rainfall (SLAC, 1994). However, local recharge may be higher due to over-irrigation, or broken water lines. In the area of the UST excavation, recharge from rainwater and/or surface runoff appears to be significant since the total dissolved solids content (TDS) of this water is much lower (about $300 \mathrm{ppm}$ ) than the surrounding wells (> 4,000 ppm).

The nearest water supply wells that are downgradient (east/southeast) from SLAC are two domestic wells located about one mile south (well 46) and 1 mile southeast (well 26) of the LINAC (Figure 3). There is no information in the record on the location of the screened interval in these wells, however, given the construction of other nearby supply wells, and the local geology, they are probably screened over a long (> 50 feet) interval deep within Tertiary bedrock.

The San Mateo ground water basin is designated for municipal, domestic, agricultural, and industrial beneficial uses in the San Francisco Bay Regional Water Quality Control Board Basin Plan (proposed 1995).

CHRONOLOGY AND POLLUTANT DISTRIBUTION

Underground Storage Tank Area

In 1965 a 3,500 gallon capacity steel underground storage tank was installed about 10 feet below grade, adjacent to the Plant Maintenance Building ( $\mathrm{DOE}, 1988$ ). This tank was used to store 
1. 然 W.

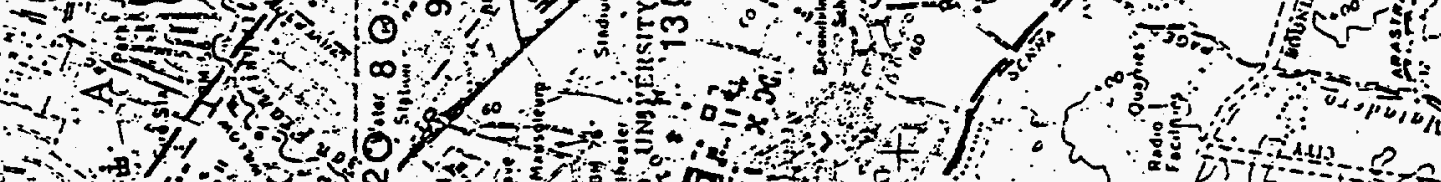
2. H

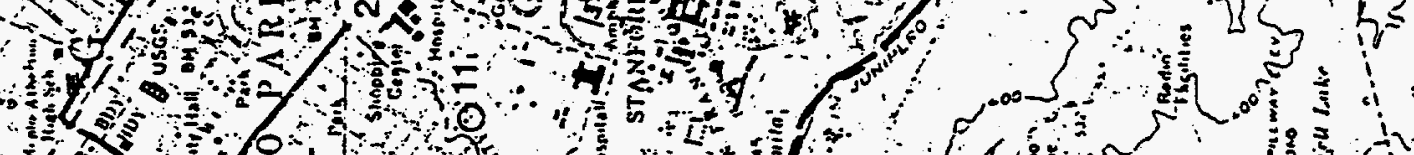

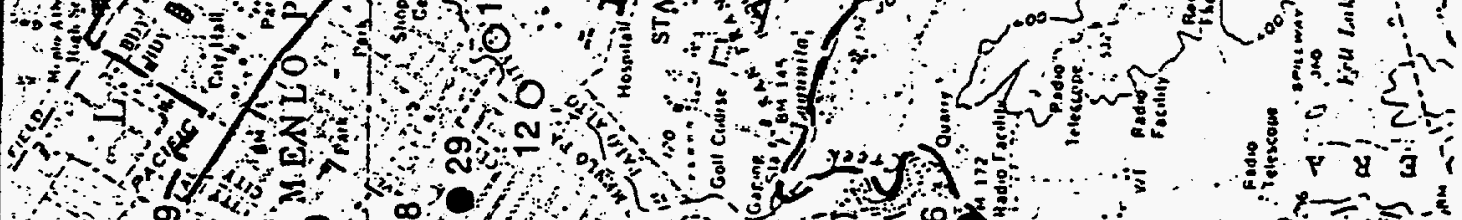

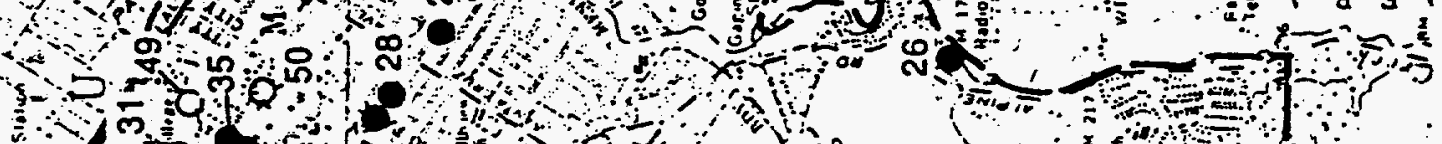

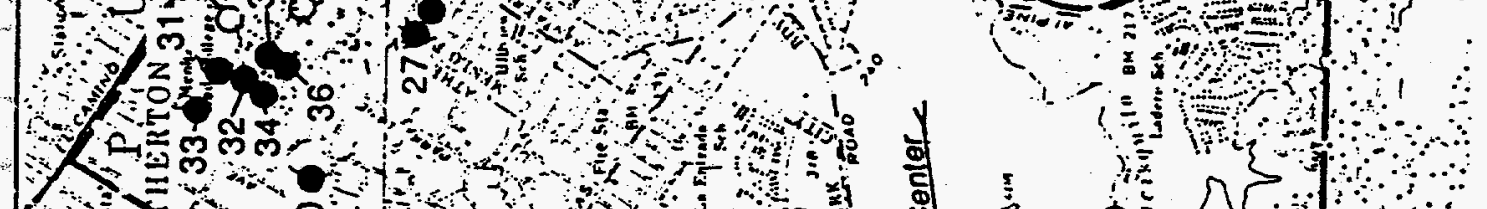
Whon

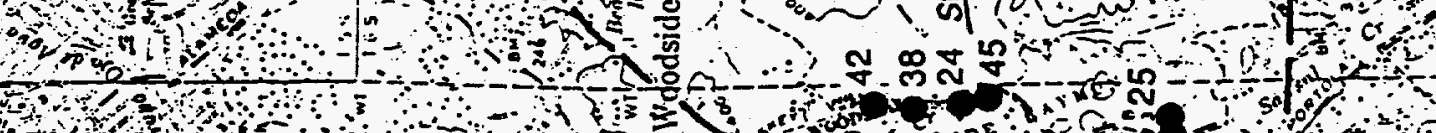

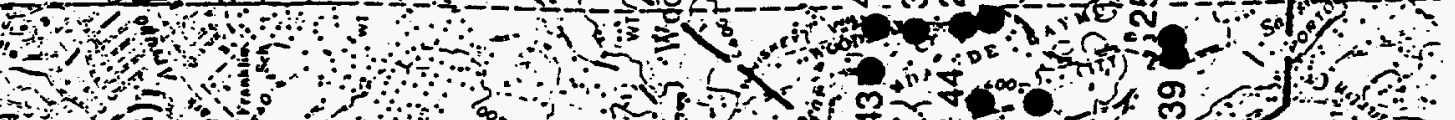

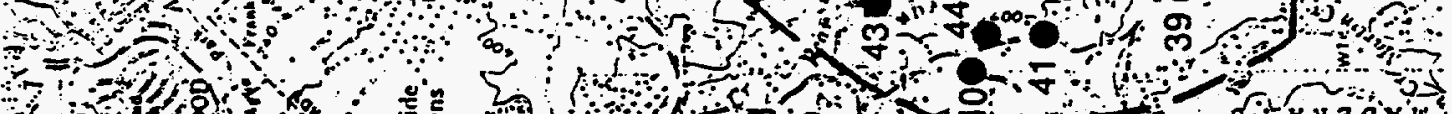
1.5

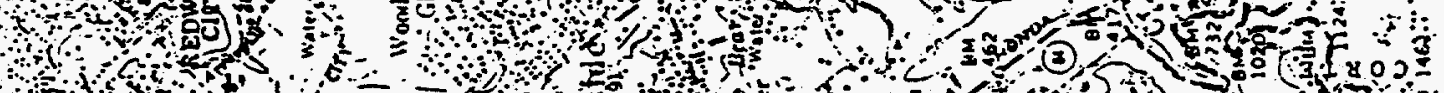
(W)

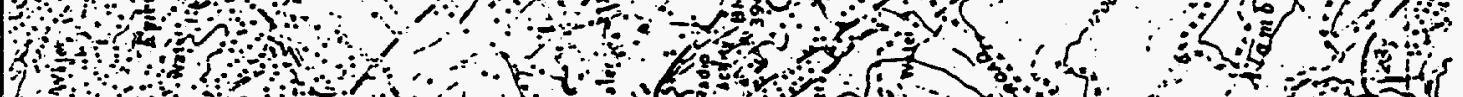
W
3 
waste solvents from various operations at the site until 1978 . It was then pumped $d r y$ and abandoned in place without being filled with cement. In December 1983, the tank failed a pressure test and prior to removal, "liquid" ${ }^{2}$ was found to have re-entered the tank. About 1800 gallons of this liquid was then pumped from the tank, and the tank was removed.

An inspection of the excavated tank revealed several $1 / 2$ to 1 inch holes caused by corrosion (SLAC, 1995). These were located on both the top and bottom of the tank and, most notably, on the south end where the tank was inclined downward.

Soil samples from the excavation were collected by Emcon (1984) and analyzed for benzene, toluene, ethylbenzene, xylene (BTEX) compounds, and PCBs. Up to $2,700 \mathrm{ppm}$ of xylene were found in a sample from the bottom of the pit, however, in a sample taken six inches below the excavation bottom, the level of xylene was $.07 \mathrm{ppm}$. No soil samples were analyzed for chlorinated solvents during this sampling event. After sampling, the excavation was backfilled with rock and covered with steel plates.

In January 1984, a monitoring well (EM-I) was installed a few feet south of the tank excavation to 27 feet below grade. The ground water level in the well stabilized at about 5 feet below grade. Soil samples collected during well installation at 10 feet below grade contained up to $360 \mathrm{ppm}$ xylenes and $310 \mathrm{ppm}$ toluene. The VOC levels at 27 feet below grade were significantly lower, at about $15 \mathrm{ppm}$, methylene chloride was detected at $2 \mathrm{ppm}$. The 10 foot sample was not analyzed for chlorinated hydrocarbons. The ground water sample taken from EM-1 contained $60 \mathrm{ppm}$ methylene chloride, $14 \mathrm{ppm} \mathrm{1,1-DCE,} \mathrm{and}$ 2.2 ppm TCE.

2 There is no indication in the record whether this Iiquid was waste solvent, ground water, or a mixture of both. 
In 1984/85, Ecology and Environment (1985) conducted a two phase investigation to determine the nature and extent of soil and ground water pollution from the leaking tank. This investigation included a complete overview of regional and local geology, drilling and sampling of 14 soil borings, and installation and sampling of six shallow monitoring wells and one deep monitoring well (Figure 4). Well EM-I was also sampled.

The results of the soil investigation indicated that shallow soils north of the former tank contained $2300 \mathrm{ppm}$ methylene chloride. In a soil boring adjacent to well EM-1, a sample taken at 7.5 feet contained 17 detected compounds ranging in concentration from $0.6 \mathrm{ppm}$ (PCE) to $110 \mathrm{ppm}$ (xylenes). Methylene chloride was detected at $7.9 \mathrm{ppm}$. Methylene chloride was also detected at 22 and $20 \mathrm{ppm}$ in shallow samples (2.5-7.5 feet) from a boring about 15 feet southeast of EM-1.

Up to $10 \mathrm{ppm}$ methylene chloride were found in a sample taken during drilling of monitoring well MW- 6 (about 50 west of former tank). However, this was attributed to either laboratory contamination or paint stripping activities that have occurred at the site since the sample was taken near the ground surface. Samples taken at various depths from the remainder of the soil borings contained less than 1 ppm total VoCs or were non-detect.

The results of ground water sampling indicated an estimated level of greater than $450 \mathrm{ppm}$ methylene chloride in well EM-1. This was an estimated value since this compound saturated the detector. High levels of other volatile compounds, up to $50 \mathrm{ppm}$, were also found in the well.

In the seven wells installed in the second phase of the investigation, only low levels of (less than $20 \mathrm{ppb}$ ) of phthalates, toluene, and chloroform were detected. However, 


\section{Service Road}

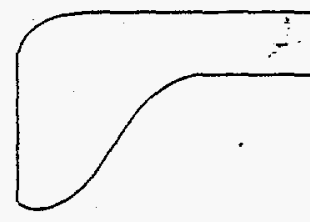

Parking Lot

MW-5

Parking Lot

Do. 81

General Services
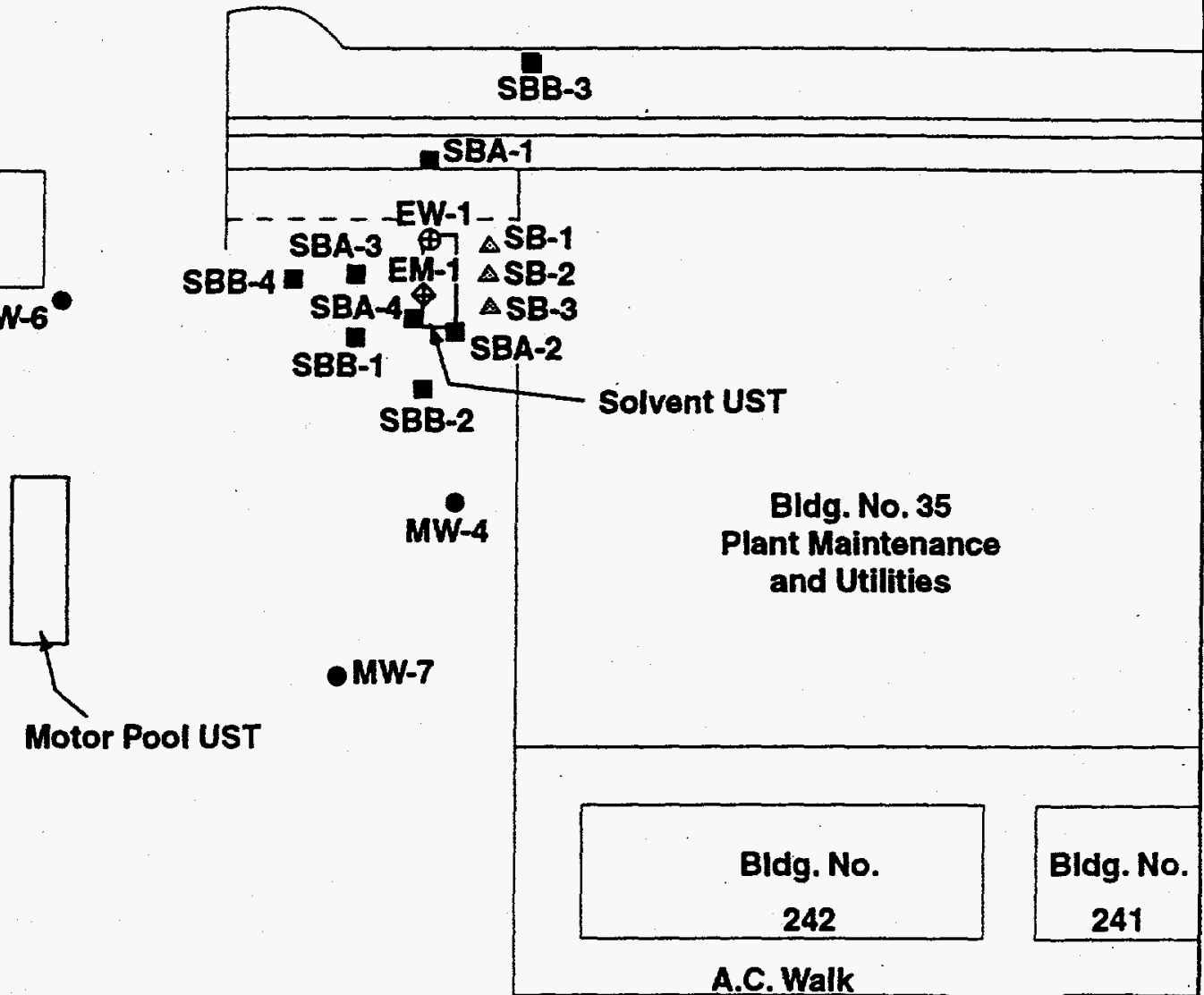

Motor Pool UST

A.C. Walk

MW-2

Parking Lot

$M W-3$

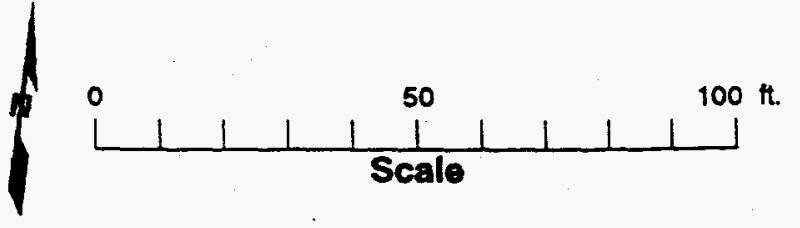

EM-1 $\odot$ Monitoring well (installed by Emcon, 1984)

MW-1 - Monitoring well (installed by E\&E, 1985)

EW-1 $\oplus$ Extraction well (installed by IT, 1986)

SBB-4 a Soil boring (drilled by E\&E, 1985)

SB-1 $\Delta$ Soil boring (drilled by GTI, 1987)

Figure 4. Map showing the location of all monitoring wells and soil borings installed in the UST Area. Modified from SLAC (1995). 
these constituents were attributed to laboratory contamination. Based on the water levels in EM-1, and MW-1 through MW-7, it was noted in the report that a ground water high area (mound) existed in the area of the former underground storage tank.

As a result of the effects of the leaking tank on soil and ground water at SLAC, the Regional Water Quality Control Board, San Francisco Bay Region (RWQCB) adopted waste discharge requirements (Order 85-88). for the site on July 17, 1985. This Order requires a series of tasks, to be completed by SLAC, to define fully the extent of soil and ground water pollution. Additionally, the order requires SLAC to cleanup the discharge so that it would not adversely affect the beneficial uses of local ground water.

In May 1986, SLAC removed additional contaminated soil by enlarging the excavation two feet south and two feet west of the original hole, and deepened it 10 feet below grade. About 88 cubic yards of contaminated soil were removed. In so doing, well EM-1 was destroyed and replaced with well EW-1 when the hole was backfilled with gravel and sealed with cement.

In September 1987, SLAC contracted to drill and sample three more soil borings located between the tank excavation and the paint shop (GTI, 1987) (Figure 3). Two of the borings were drilled to about 30 feet below grade and one to 22 feet below grade. The results of this sampling indicated vocs in soil between 5 feet and 29 feet below grade, with the highest levels in all borings found at 10 feet below grade. The major constituents detected were xylene (up to $618 \mathrm{ppm}$ ), toluene (up to $364 \mathrm{ppm}$ ), 1, 1, 1-TCA (up to $190 \mathrm{ppm}$ ), and 1,2-DCE (up to $28 \mathrm{ppm}$ ). Methylene chloride was not detected in any of the samples. 
As a result of this work, vapor extraction was proposed to remediate the residual soil pollution in the tank area. A pilot test was conducted in November 1987, but the results indicated that the radius of influence of the system was too small to allow for effective remediation. After reviewing several alternatives, GTI concluded that a health risk assessment and continued quarterly monitoring were the only feasible options. Quarterly monitoring continued, but no risk assessment was conducted.

SLAC began quarterly monitoring of wells EW-I, and MW-1 through MW-7 in January 1987 and continued until July 1995. At that time, SLAC requested (from the RWQCB) and received a modified sampling schedule of 6 month intervals.

Also in July 1995, AIP staff conducted comparison ground water sampling at SLAC in wells EW-1 and MW-2. The results were exchanged with SLAC staff in August 1995, and all analytical results of comparison sampling are listed in Table 1 . Comparison sampling for VOCs conducted by the AIP has shown no significant discrepancies between SLAC and AIP results.

SLAC staff submitted a draft workplan (SLAC, 1995) to SWRCB AIP staff for further characterization and remediation of the leaking waste solvent tank area in early December 1995.

\section{Site-wide Investigations}

In response to DOE Order 5400.1 SLAC installed a total of 10 monitoring wells (MW-21 to MW-30) in 1990, near the plating shop, hazardous materials disposal area, and end beam area (see Figure 2). These are locations which stored, handled, or used chemicals which may pose a threat to ground water quality.

Wells MW-21, 22, and 23 were installed in the plating shop area. 


\begin{tabular}{|c|c|c|c|c|}
\hline \multirow[t]{2}{*}{ Dur } & \multirow[t]{2}{*}{ Wors } & \multirow[t]{2}{*}{ Nunsta' } & anowes (RP) & \multirow[t]{2}{*}{$D L *=.5$} \\
\hline & & & sinc & \\
\hline \multirow[t]{13}{*}{$7-25-95$} & \multirow[t]{12}{*}{$E W-1$} & $1,1-D C A$ & 450 & 367 \\
\hline & & $1,1-D C E$ & 26 & 37.7 \\
\hline & & CIS 1,2-DCE & 160 & 149 \\
\hline & & $P C E$ & 4.3 & 5.7 \\
\hline & & $1,1,1-\mathrm{TCA}$ & 97 & 100 \\
\hline & & $T C E$ & 7.6 & 11.1 \\
\hline & & ETEYIBBMNZ & 6.4 & 5.7 \\
\hline & & TOLUENE & 1.9 & 3.2 \\
\hline & & XYLFIES & 14 & 14.9 \\
\hline & & BEANZEAEE & 0.44 & ND \\
\hline & & $1,3-D C B$ & 2.1 & NDD \\
\hline & & $1,4-D C B$ & 0.89 & ND \\
\hline & $M-2$ & vocs & ND & ND \\
\hline
\end{tabular}

* $\quad$ DL $=$ Detection Limit

1. SLAC used EPA methods $8010 / 8020$, SWRCB used EPA methods $601 / 602$ modified.

2. VOC constituents not listed were not detected by either party.

Table 1.

Results of comparison sampling of vocs for two wells in the UST Area. 
Initial sampling results for total VoCs in MW-21 were less than $50 \mathrm{ppb}$, but VOC levels have steadily increased to over $400 \mathrm{ppb}$ in the past 5 years. In well MW-22, initial results showed $3000 \mathrm{ppb}$ total VOCs, however, VOC levels fluctuated down to $1000 \mathrm{ppb}$ in July 1991 and up to $4500 \mathrm{ppb}$ in October 1993. Initial VOC results for MW-23 were about $1200 \mathrm{ppb}$, but after the first sampling event VOC levels have steadily remained below $30 \mathrm{ppb}$ total vocs.

Wells MW-25, 26, and 27 are located in the hazardous materials disposal area. Initial results for VOCs from MW-25 showed approximately 20 ppb total VOCs, however, VOC levels have steadily increased to about $190 \mathrm{ppb}$ in November 1994. In MW-26, VOC levels have consistently been below 2 ppb, although up to $12 \mathrm{ppb}$ have been detected in this well. Total VOCs in MW-27 have remained below $2 \mathrm{ppb}$.

Wells 28, 29, and 30 are located in the end beam area. Total Vocs in MW-28 have fluctuated between non-detect and a maximum of $13 \mathrm{ppb}$. As of November 1994, total VoCs in this well were less than $1 \mathrm{ppb}$. In MW-29, total VOCs have remained below five ppb throughout quarterly sampling. Total VOC levels in MW-30 (Freon 113 only) steadily rose from $4 \mathrm{ppb}$ in January 1991 to $116 \mathrm{ppb}$ in January 1993, but have since decreased to $57 \mathrm{ppb}$ in November 1994 .

In 1992 SLAC conducted a soil gas survey in both the Plating Shop and the Hazardous Materials areas in order to help determine the source of VoCs in ground water in these areas (discussed below).

\subsection{DISCUSSION AND ANALYSIS}

UNDERGROUND STORAGE TANK AREA 
As with any case of polluted ground water, the problem begins with the source -- in this case, a 3,500 gallon capacity underground waste solvent tank. Since the tank was made of steel and had no cathodic protection, it was subject to severe corrosion. This inevitably led to the occurrence of several holes in both the bottom and top of the tank. Waste solvents leaked through these holes during at least part of the 11 year period the tank was in operation.

Since we do not know the time the holes first appeared, and since no records were kept of the amount of waste that went in to the tank versus the amount that was pumped out of it, the total volume of leakage is unknown. Between the period of final pumping of the tank and abandonment in place in 1978, and the time of tank removal in 1983, at least 1800 gallons of "liquid" leaked back into the tank through the rust holes (SLAC, 1995). There is no indication in the record what this liquid was, i.e. ground water, waste solvent, or a mixture of both. If the liquid was solvent, then the tank leak was quite large.

Clearly, the severity of the leak would have been most notable at the time of tank removal. However, SWRCB staff were not able to obtain and review the tank removal report, although it was requested it several times from SLAC and DOE staff. Given the ground water in the tank area has historically been about 10 feet below grade, the tank essentially leaked directly into ground water.

According to the record, the base of the tank excavation is composed of a north dipping impermeable layer of rock on which ground water is "perched". If this is the case, then it is possible that most, or some, of the leaked solvent also accumulated on top of the layer and then leaked back into the tank after it was emptied during abandonment. This solvent would 
have then been removed when the tank was pumped and excavated. Any remaining solvent would have escaped into the ground. Chlorinated solvents, such as the type that were disposed of into the tark, can form a non-aqueous phase (NAPL) that is more dense than water. As a result, once this dense NAPL enters ground water, site geology controls the migration of NAPL, and ground water flow controls the migration of the dissolved phase. In such a scenario, the two phases could travel along different migration pathways.

The tank area is located between stations 80 and 90 of the IINAC. The geology of this area is more complex than the other areas studied. This is due to the fact that the contact between the Eocene and Miocene rocks lies directly below the tank study area (Figure 5). Additionally, this contact represents the eastern limb of an anticline, with chaotic Eocene rocks underlying Miocene rocks. The average dip of the eastern limb is about $45^{\circ}$. Given this, any NAPL not removed with the tank may have flowed downward along the east dipping bedding planes of the Tertiary rocks, or along fractures. Evidence that NAPL remained in the ground after tank removal is indicated by the presence of greater than 450,000 ppb of methylene chloride in well EM-1 when it was sampled by in 1985 .

However, samples from the soil borings drilled east of the former tank did not contain detectable levels of methylene chloride at any of the depth intervals sampled (sampled every 5 feet to depth of boring). Nevertheless, at the 10 foot interval in all three borings, several other VoCs were detected. Of these, toluene, xylenes, and $1,1,1-$ TCA were found at the highest concentrations (618 ppm, 364 ppm, and 190 ppm respectively).

Figure 6 shows a series of contour/surface maps of the ground water table in the vicinity of the former solvent tank from 


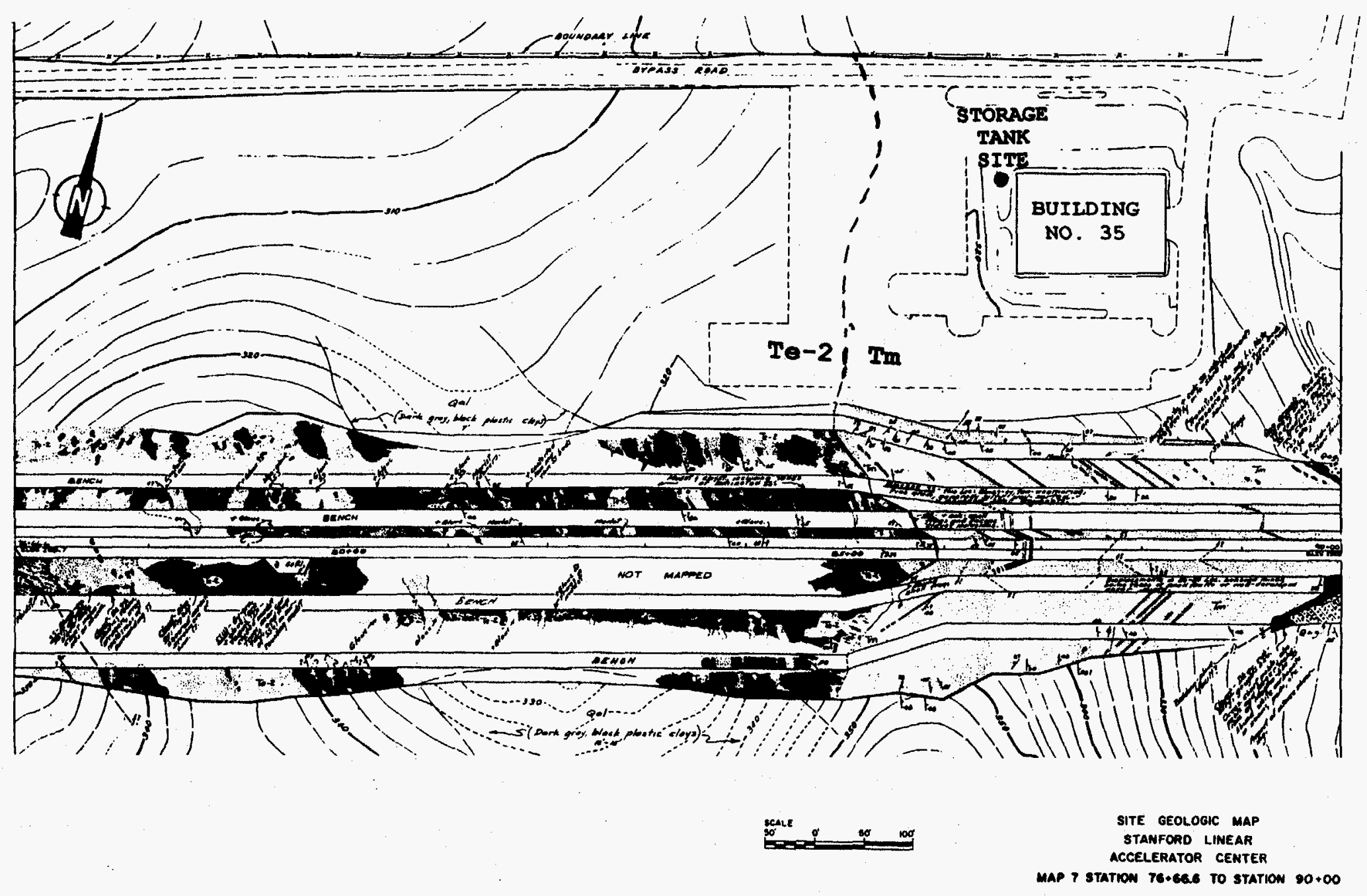

Figure 5. Geologic map of the LINAC excavation, which is about $300 \mathrm{ft}$ south of the UST area. Units $\mathrm{Te}-2$ and $\mathrm{Tm}$ represent chaotic Eocene rocks, and Miocene rocks respectively. Note projection of the Eocene/Miocene contact. Modified from Aetron, Blume, and Atkinson (1965). 
JANUARY 1987

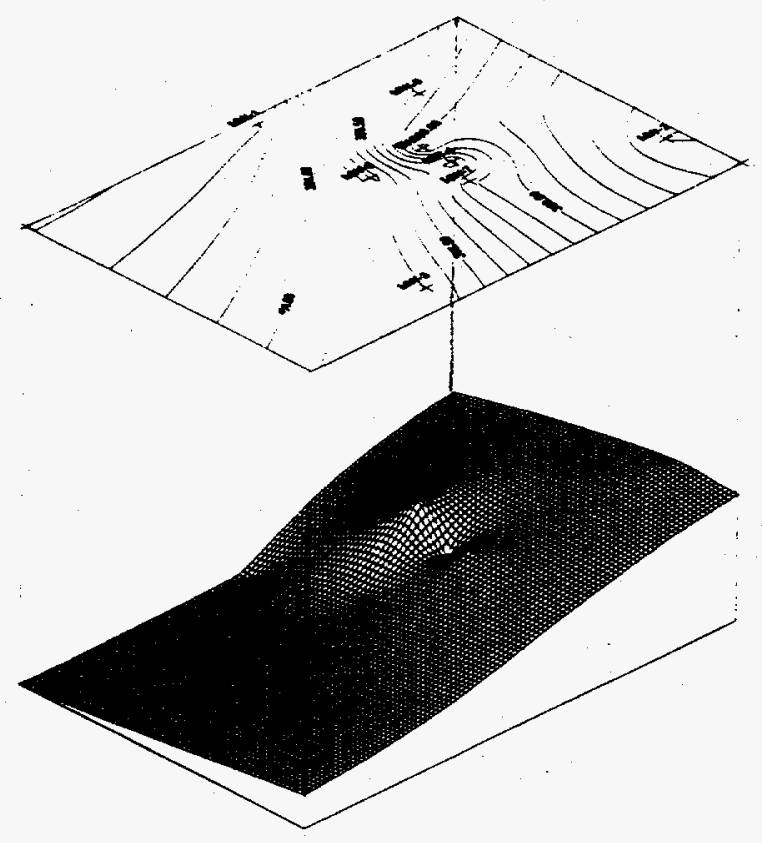

JANUARY 1988

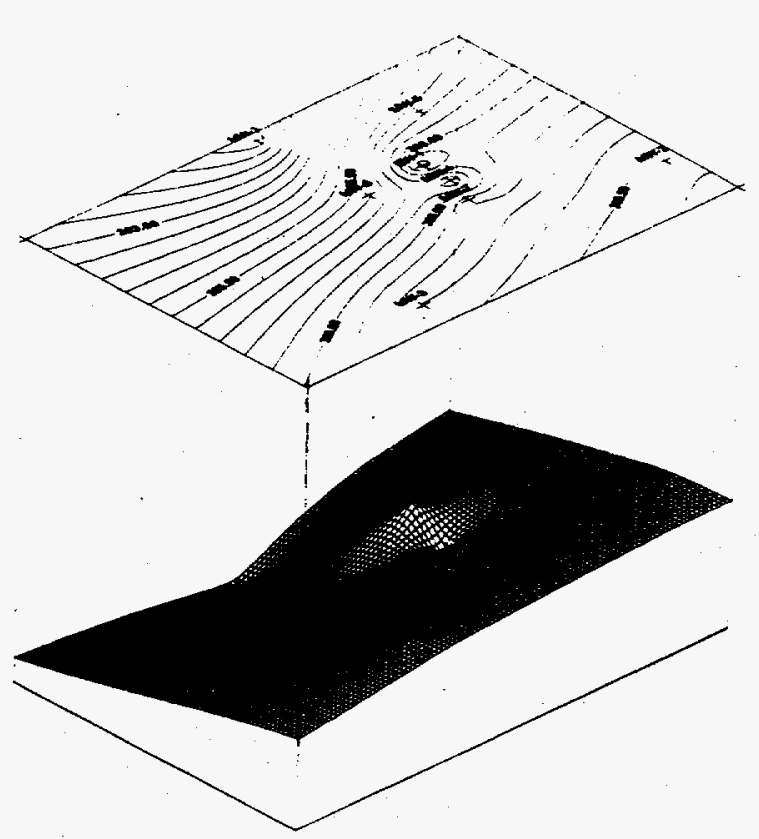

JANUARY 1990

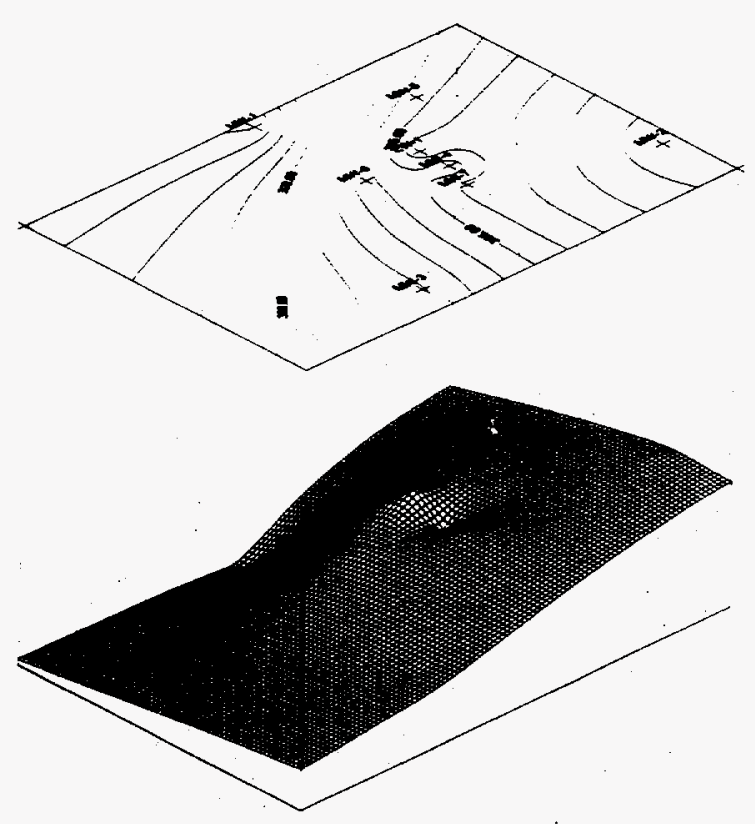

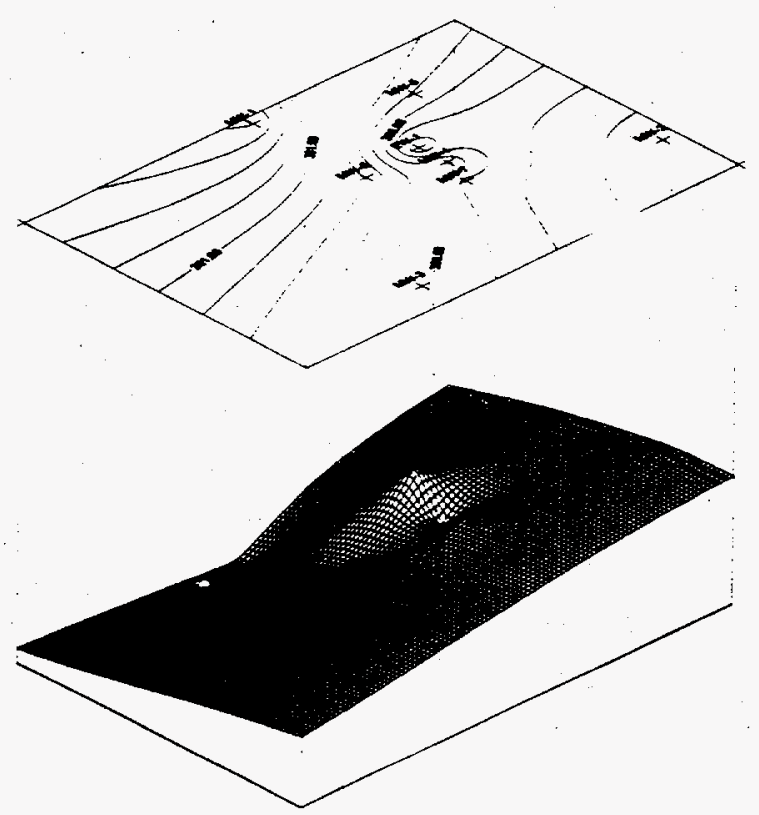

Figure 6. Sequence of ground water contour/surface maps of the UST Area from January 1987 to July 1993 (three pages). Note the $180^{\circ}$ shift in the ground water gradient, and the ground water mound at EW-1, and trough at MW-4.

STATE WATER RESOURCES CONTROL BOARD 95 ATP SUMMARY REPORT 

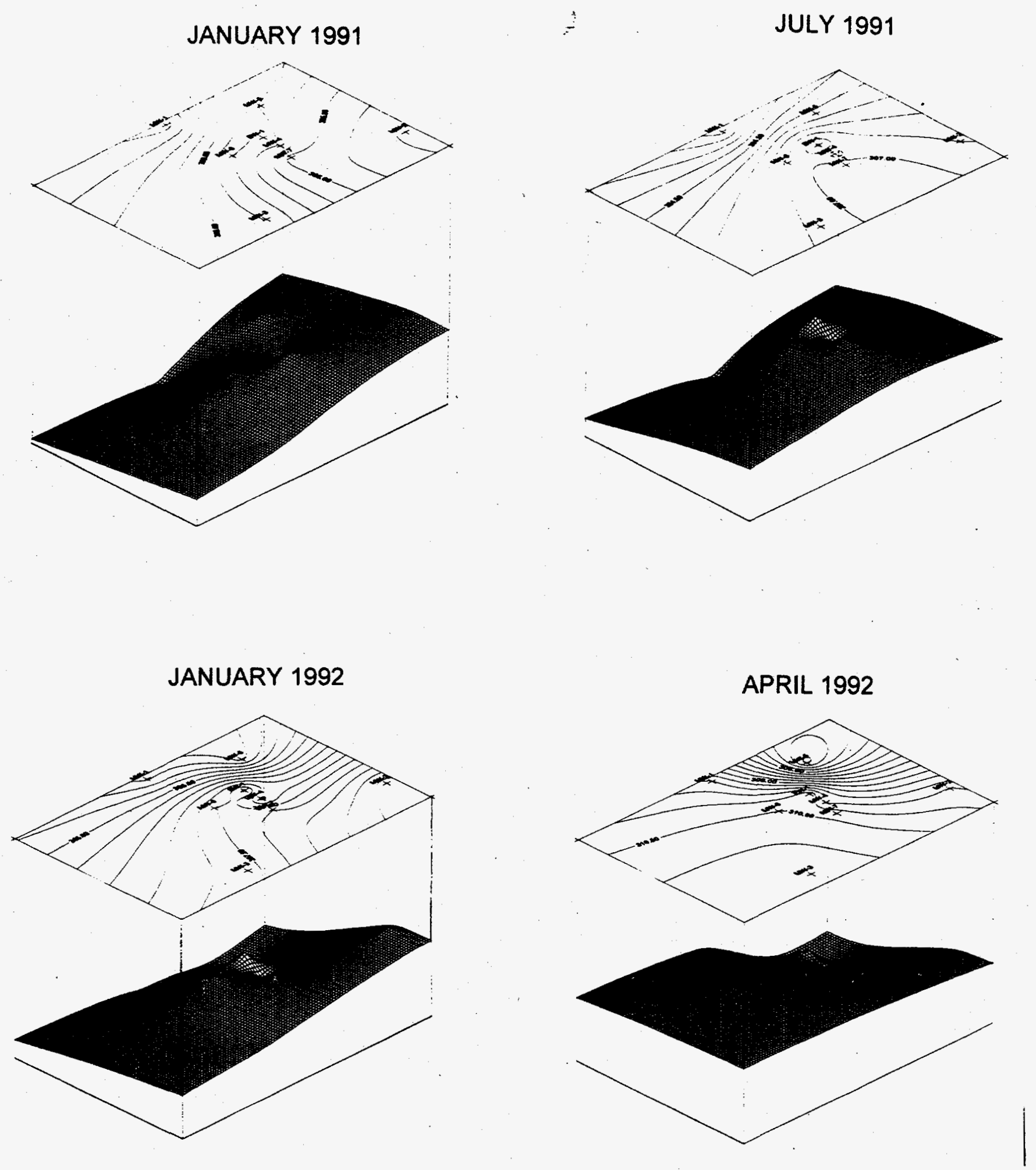

Eigure 6 continued 

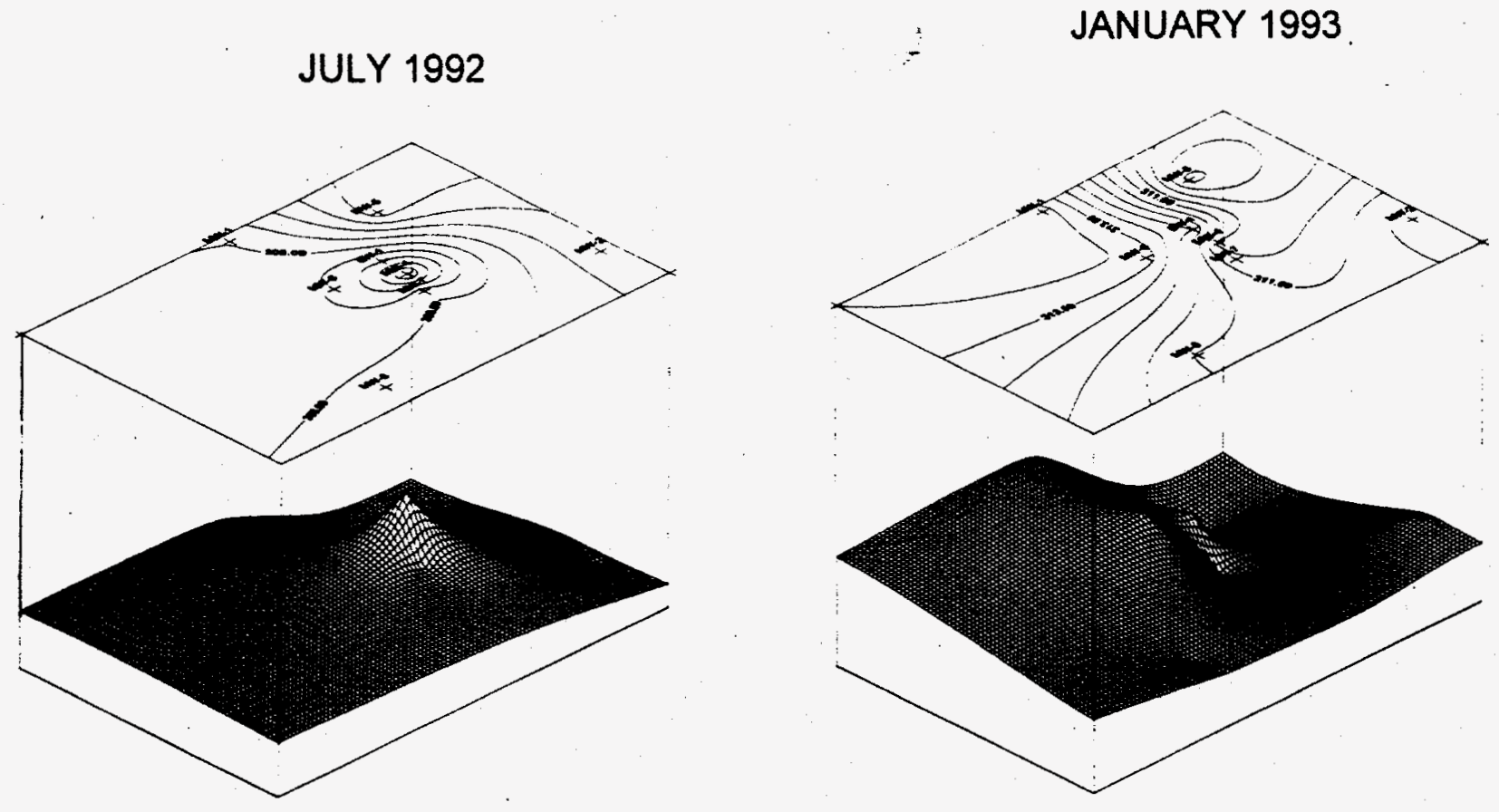

JULY 1993

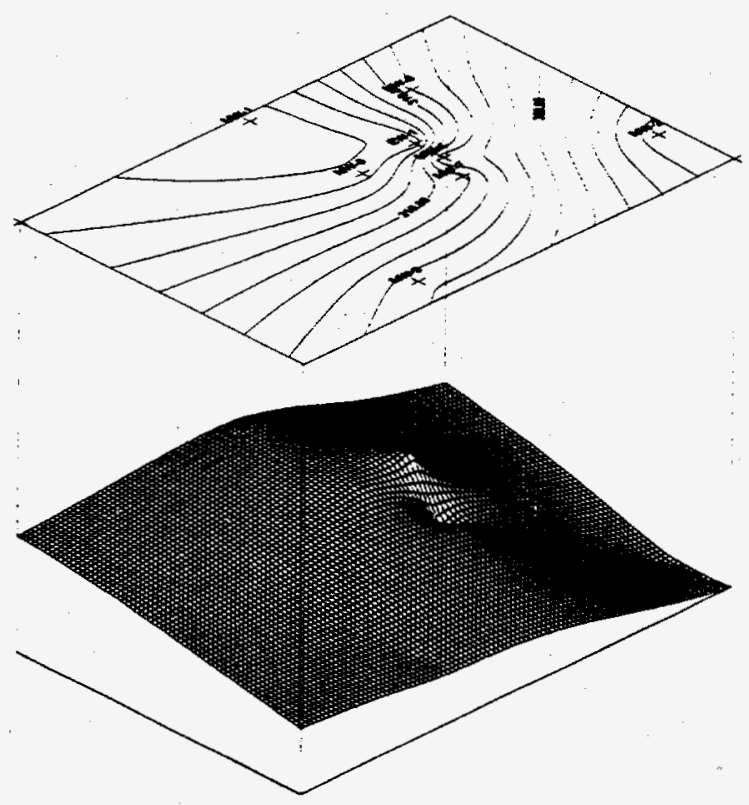

Figure 6 continued 
January 1987 to July 1993. Data from wells EW-1 and MW-4 are included in these maps since the hydrographs of these wells (Figure 7) indicate they are interconnected with the same ground water zone of the other wells, although they are screened at different intervals ${ }^{3}$. EW-I is screened only in the excavation gravel backfill and not in the Miocene rocks where the other wells are screened (Figure 8). There are two important facts to note in these maps:

1. The ground water gradient rotated clockwise from northwest to southeast over 18 months after remaining in a northwest direction for several years.

2. A ground water mound occurs in the area of EW-1, and a ground water trough occurs in the area of $\mathrm{MW}-4$.

Both SWRCB and SLAC staff have been unable to determine the reason for the sudden shift of the ground water gradient in the tank area. The initial northwest direction of ground water flow was opposite of the regional gradient which has historically been east/southeast. Whatever local influences on the ground water that have caused it to flow opposite the regional direction (e.g. leaking pipes, over irrigation, broken storm sewer) either stopped, or were overridden by those factors that caused it to shift $180^{\circ}$.

Since the LINAC excavation (300 feet south of the tank area) extends below the water table, several sumps were installed along the IINAC to keep the water table below the excavation. This could be a factor in the gradient shift.

${ }^{3} \mathrm{All}$ of the wells in the tank area, except $\mathrm{EW}-1$ and $\mathrm{MW}-4$ are screened approximately 10-30 feet below grade. EW-1 and MW-4 are screened 5-10 feet and 40-80 feet below grade, respectively. 


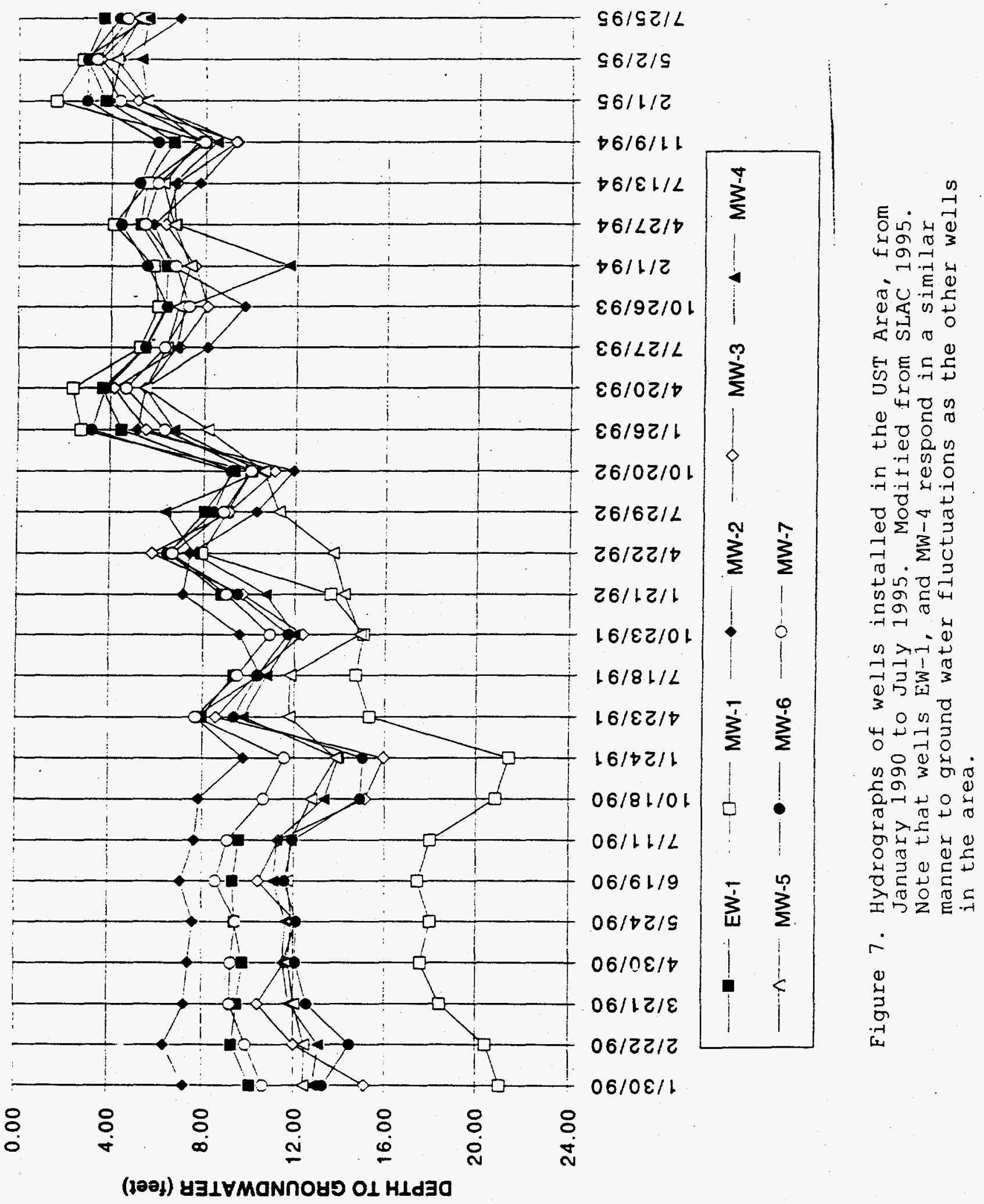




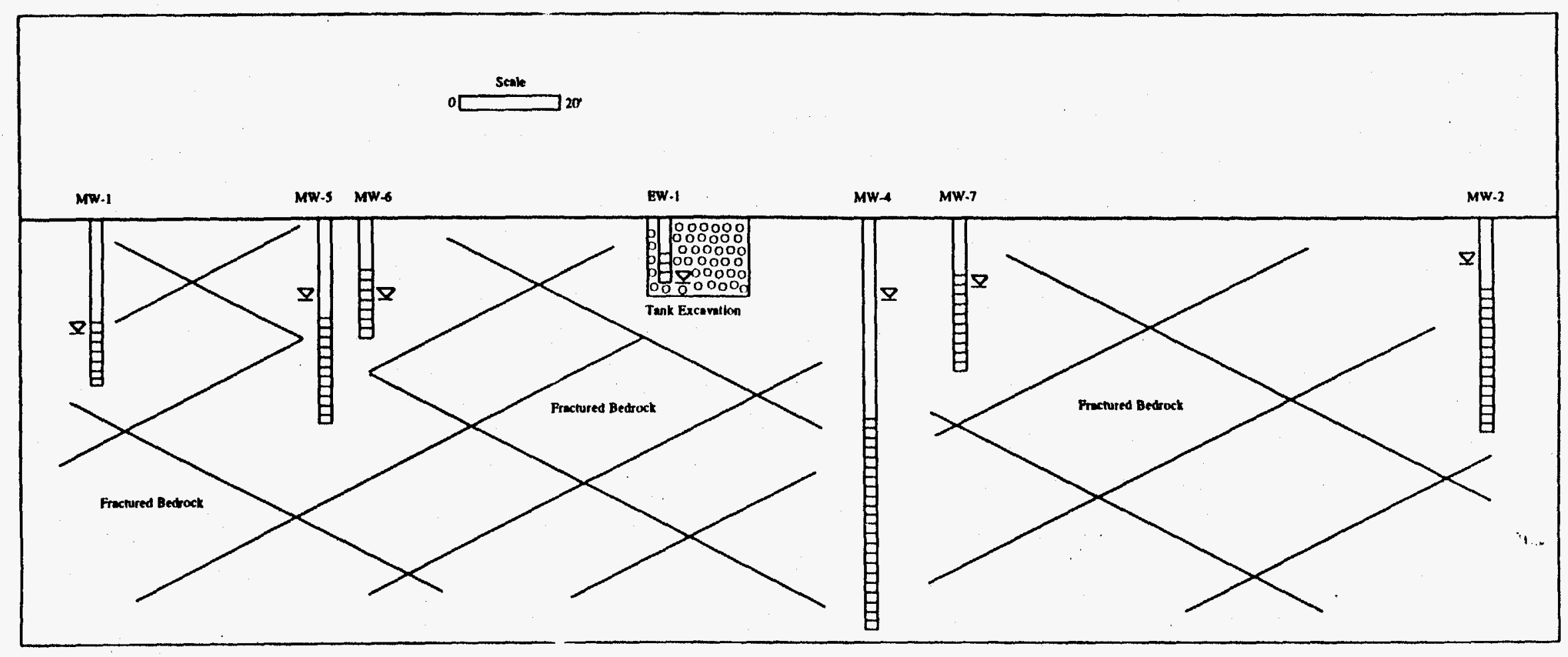

Figure 8. Drawing showing the contruction, and spatial. relationships relative to the tank excavation, of the wells in the UST Area. Ground water levels for January 1990 are shown. No vertical exaggeration. 
Clearly, one of the factors causing the ground water mound at $\mathrm{EW}-1$ is that the well is screened in gravel backfill and not the formation. The difference in permeability of these two units is tremendous, and any rainfall or surface runoff that might flow into the excavation will create a ground water mound since inflow is much faster than outflow into the formation.

The TDS content of ground water in EW-1 is about $300 \mathrm{ppm}$, considerably less than the 4000 to $8000 \mathrm{ppm}$ found in the other wells in the tank area. This is further evidence that the ground water in EW-1 is being recharged with low TDS water such as rain water or a man-made source at SLAC. Stable isotope data from EW-1 would confirm the origin of ground water in the well.

Ecology and the Environment (1985) reported a ground water mound in the tank area (prior to installation of EW-1) and attributed it to:

1. Leakage from a broken storm sewer line directly below the tank site;

2. Excessive watering of nearby vegetation; and

3. Possible leakage from buried irrigation lines located north of the plant maintenance building.

The ground water trough around well MW-4 occurs because the well is screened in a zone of slightly lower head than the shallow wells. This indicates a downward component of the ground water gradient at the site. However, the actual head difference between the shallow and deep zones cannot be determined from the well since it represents the average head over a 40 foot screened interval. This vertical gradient may be caused by pumping from the LINAC excavation as it is lower in elevation than the tank area. 
Figure 9 shows the concentrations of total VOCs in EW-1 throughout quarterly monitoring of the well, and also the concentration of total vocs in the other wells in this area. Two separate graphs are used since the concentrations in EW-1 were several orders of magnitude higher than the other wells. The key points to note from these charts are:

1. The concentration of total VOCs in EW-I has dropped from 230,000 to less than 1,000 ppb (SLAC, 1994), and methylene chloride is no longer detectable. Methylene Chloride was originally detected at 160,000 ppb.

2. The concentration of total VoCs in well MW-5 increased from non-detect to a peak of $162 \mathrm{ppb}$ in January 1993, then dropped to $58 \mathrm{ppb}$ in october 93.

The most probable explanation for the significant decline in total VOCs in EW-I is the compounds have either volatilized out into the atmosphere through the permeable gravel, and/or, have been flushed out by periodic recharge of the ground water through the backfill, from rain or surface runoff. Some biodegradation may also be occurring.

The steady increase in total VOCs in MW-5 is directly related to the shift in the ground water gradient from northwest to southeast. As the gradient passed through the northeast, vocs began appearing in MW-5, increasing to a peak then declining as the gradient shift continued to the southeast.

SITE-WIDE INVESTIGATIONS

Figure 10 shows a sequence of ground water surface maps for the entire site from January 1992 to January 1993. These maps show that the regional ground water gradient has remained to the 


\section{TOTAL VOCS UST AREA \\ WELLS EW-1, AND MW-1 TO MW-7}

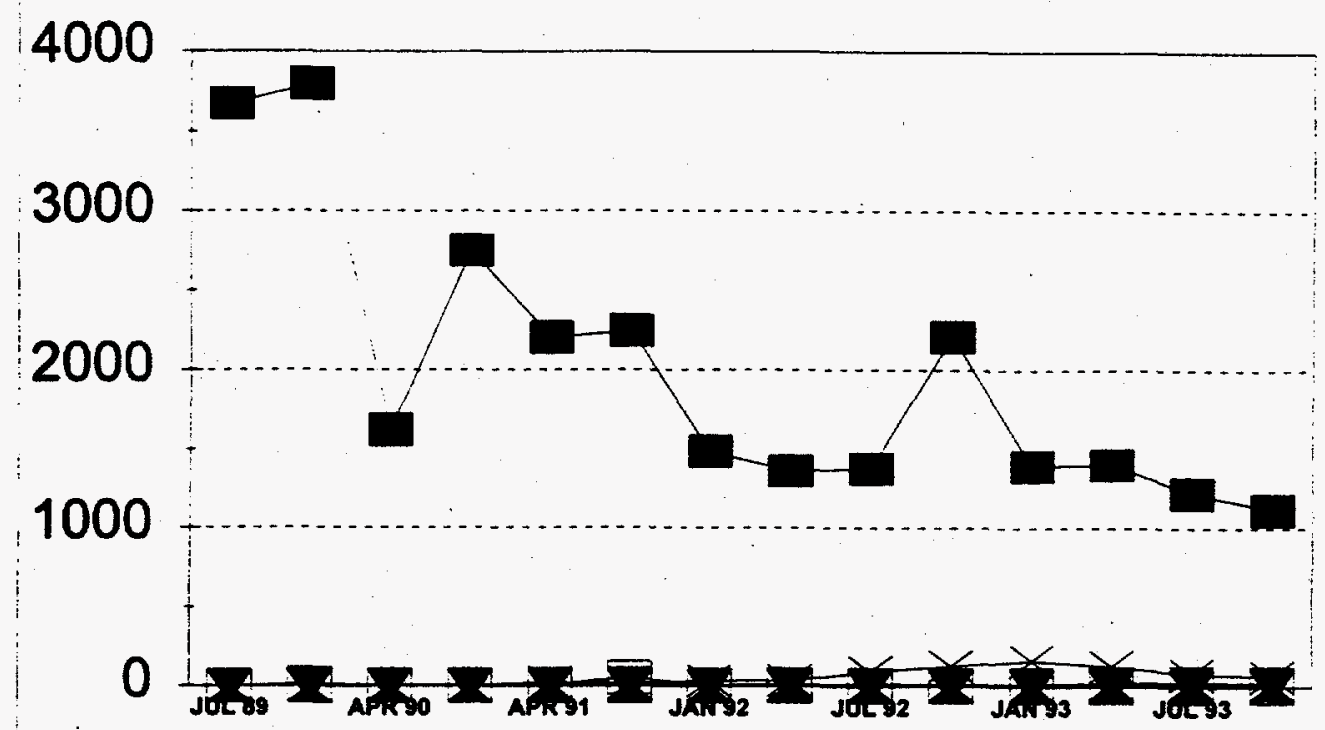

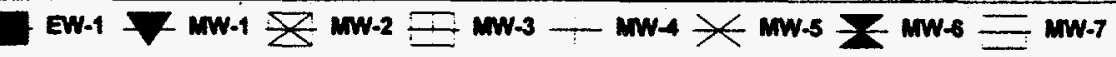

\section{TOTAL VOCS UST AREA}

WELLS MW-1 TO MW-7

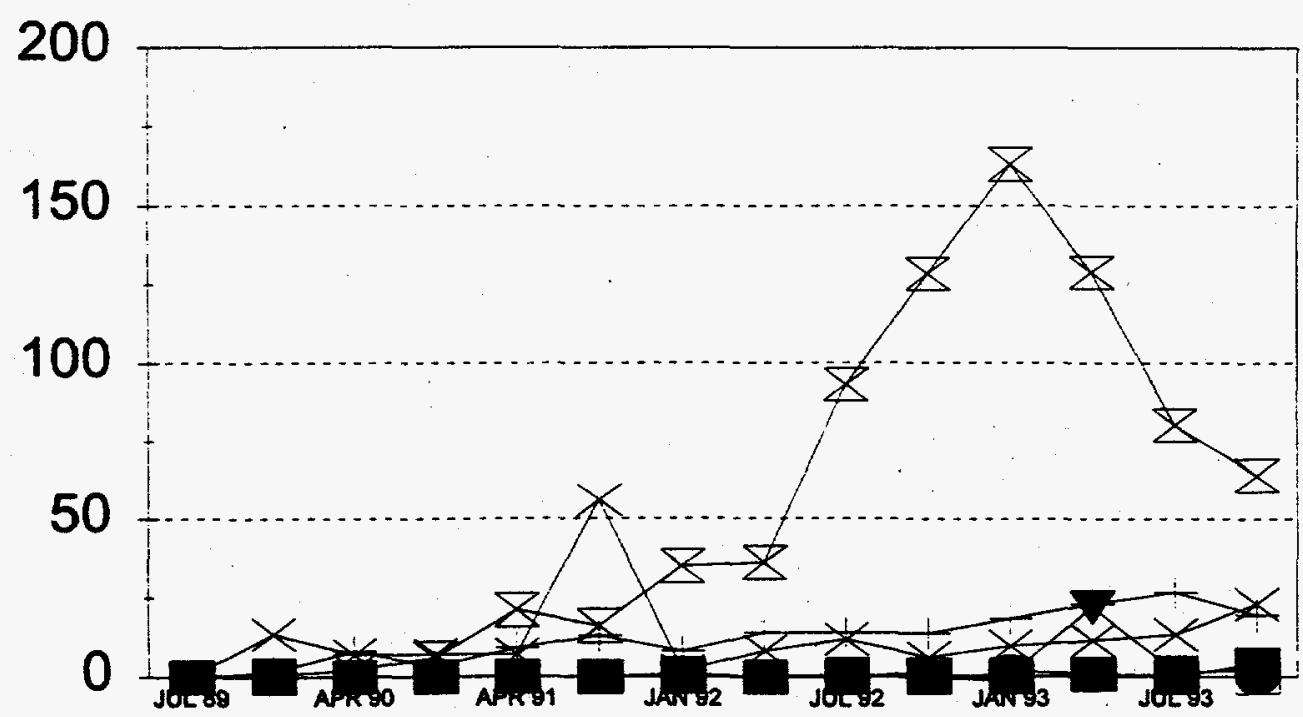

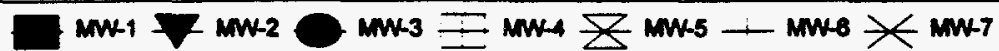

Eigure 9. Total VOCs in ground water wells installed in the UST Area from July 1989 to October 1993. Two sets of graphs are used since EW-1 contains significantly more VOCs than the other wells. VOC concentrations are in ppb. First sample from EW-1 contained 230000 ppb, but not included since this would completely throw off the scale. 

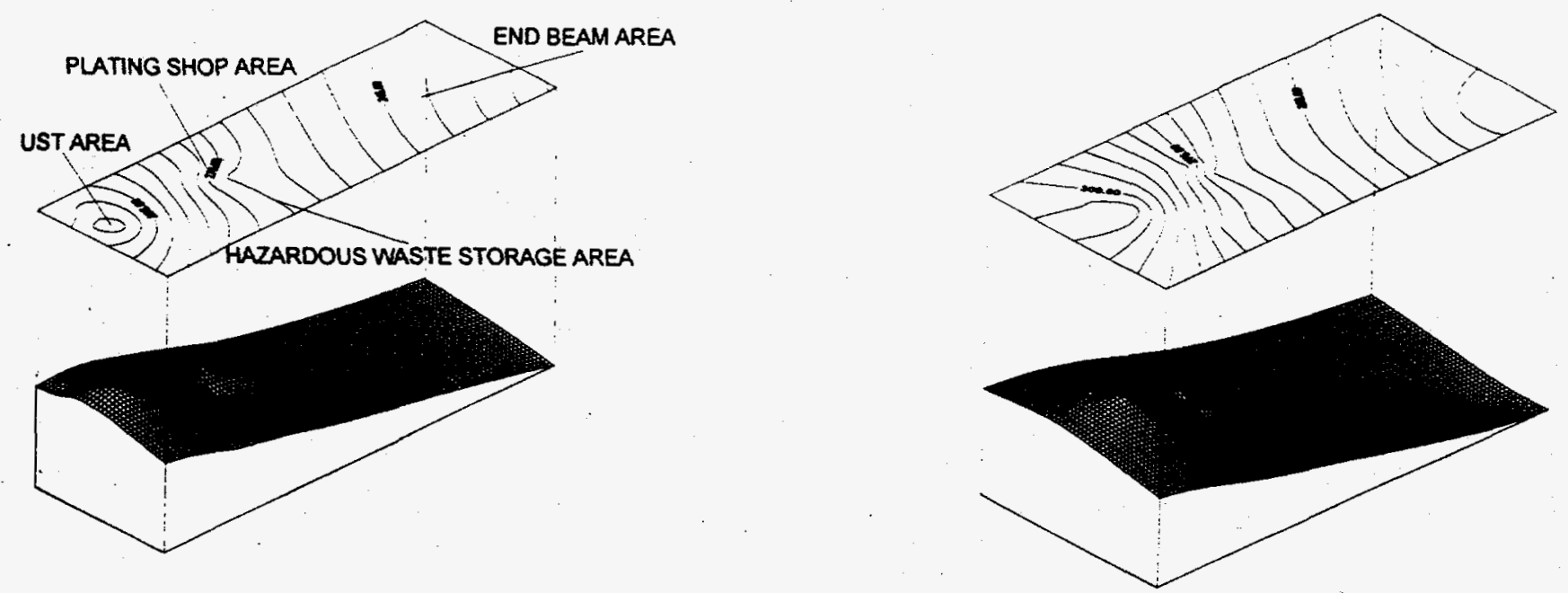

JANUARY 1993

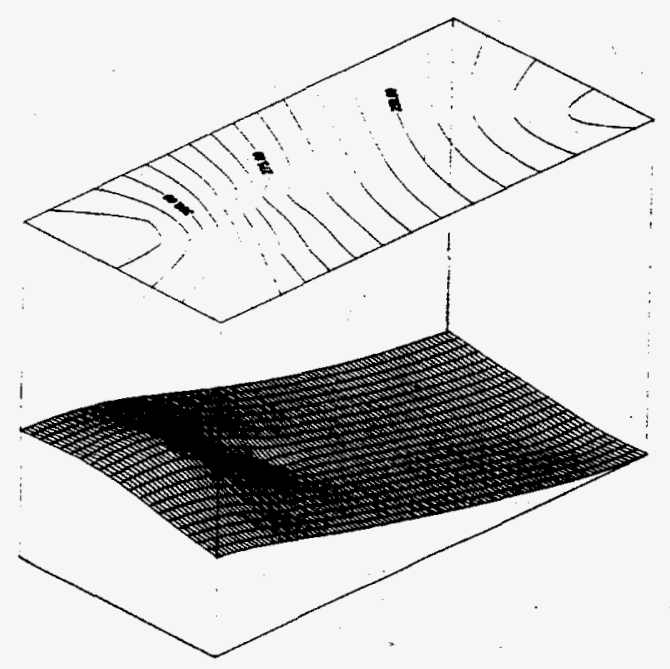

Figure 10. Ground water contour/surface maps of the entire site from January 1991 to January 1993. 
east/southeast throughout quarterly sampling of the wells installed for site-wide investigations. Three wells (MW-21, 22, 23) were installed in the Plating shop Area because leaks had been found in the Plating shop waste water line during line excavation in september 1984. Well 24 was installed to monitor a former leaking diesel fuel pump. Figure 11 shows the concentration of total vocs in all four wells from October 1990 to October 1993 .

Clearly from these charts, $M W-22$ is closest to the source of VoCs in $M W-21,22$, and 23 since it contains the highest concentrations. Downgradient well MW-2I has been steadily increasing in concentration of total voCs since it was installed in 1990. Cross-gradient well MW-23 only contains very low levels. of VOCs.

In 1992, SLAC conducted active soil gas surveys at the Plating Shop and Hazardous Materials areas of the site in order to help determine the source of Vocs in ground water there. Soil Gas surveys collect and analyze the soil pore gas for VoCs that volatilize from the soil and/or ground water, via probes buried in shallow soil. In so doing they can provide data to help determine where the highest concentrations of Vocs are located and hence, the source area.

However, the effectiveness of this technology decreases with decreasing soil permeability, since a good gas sample cannot be drawn from impermeable material (clays etc.). In the plating Shop Area, some of the gas samples were unobtainable or unreliable due to the low permeability subsurface, however, enough good samples were collected to draw some preliminary conclusions. 

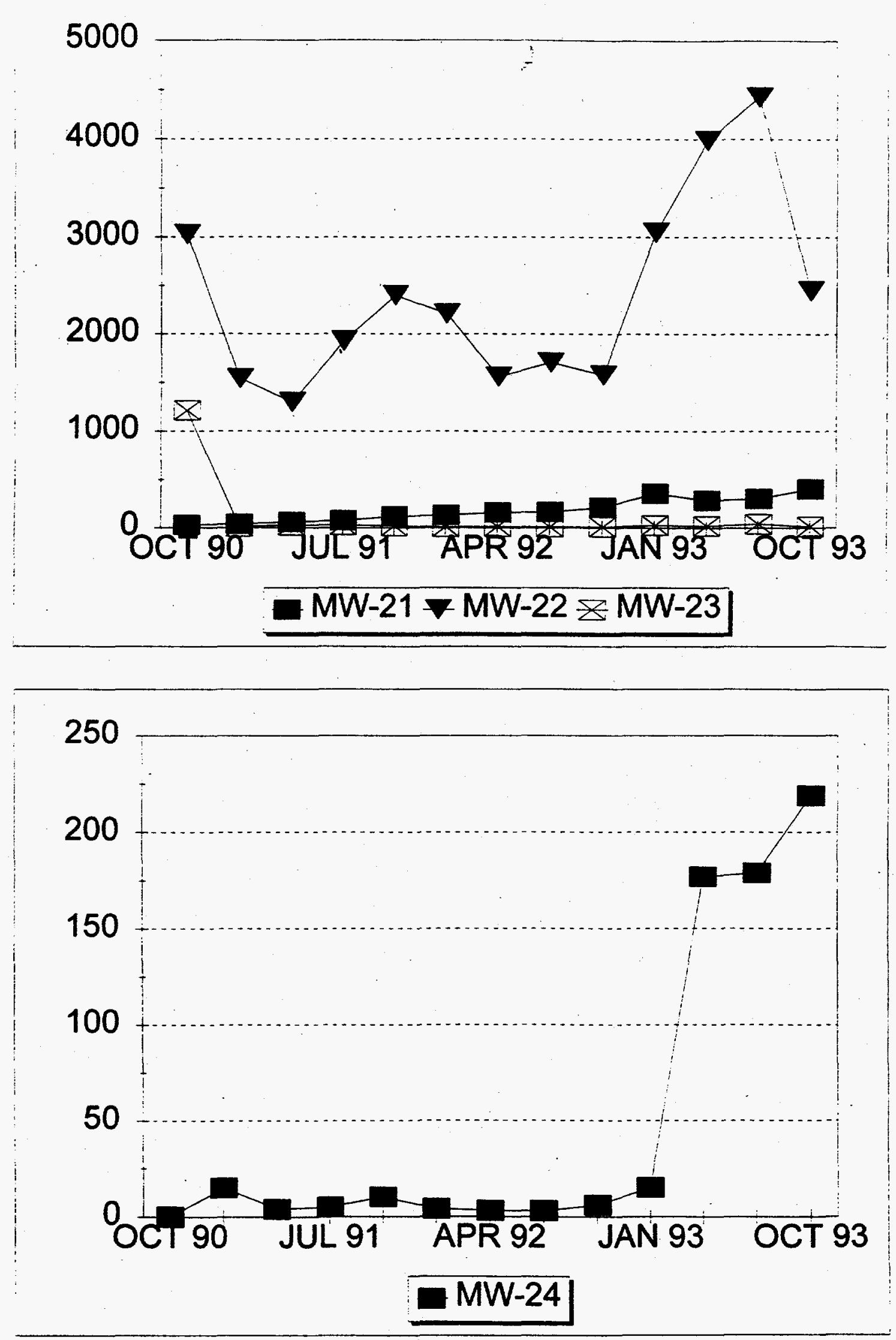

Figure 11. Total vocs (in ppb) in ground water in wells installed in the Plating Shop Area, from October 1990 to October 1993. 
The highest concentrations of VoCs in soil gas were found about 100 feet north of MW-22. Low level of VoCs in soil gas were also found about 100 feet southeast of MW-23. This data indicates the source of VOCs in the Plating Shop Area is probably somewhere northwest of MW-22.

The soil gas survey in the Hazardous waste Storage Area was not successful. This is because reliable soil gas samples could not be collected due to the high clay content of the subsurface materials.

Although MW-24 was installed to monitor leakage from a diesel fuel pump and some diesel components were found in the well, TCE and 1,2-DCE have also been detected in the well. Total VOCs have been steadily increasing in concentration (up to $220 \mathrm{ppb}$ ) throughout quarterly monitoring. The source of chlorinated vocs in MW-24 needs to be determined.

Figure 12 shows the concentration of total VoCs in the wells installed in the hazardous waste storage area (MW-25, 26, and 27) and the End Beam Area (MW-28, 29, and 30) from October 1990 to October 1993. Very low levels of vocs have been detected in MW-26 and no VOCs have been detected in MW-27. However, VoCs in MW-25 show an increasing trend from the initial concentration of $20 \mathrm{ppb}$ to over $160 \mathrm{ppb}$ in October 1993. The source of vocs in MW-25 needs to be determined.

In wells MW-28 and MW-29, total VoCs are less than $10 \mathrm{ppb}$, while VOC levels in MW-30 have steadily increased to $60 \mathrm{ppb}$. These wells are too far apart to have the same source. Since VoCs have remained stable at very low levels in MW-28 and 29, and well MW-30 only contains Freon 113 at levels far below the $1200 \mathrm{ppb} \mathrm{MCL}$, we do not recommend further work in this area. 
200

150
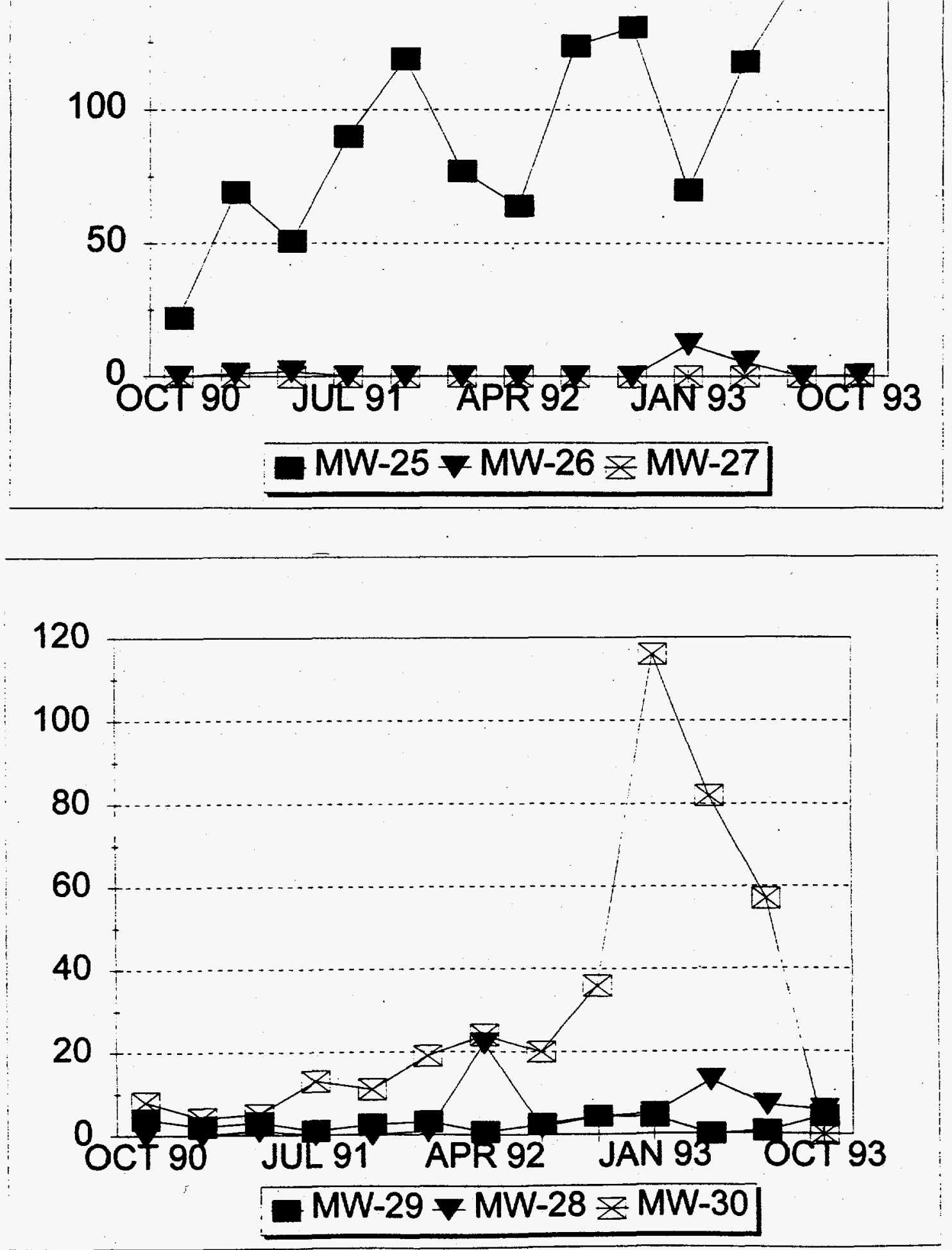

Figure 12. Total Vocs (in ppb) in ground water in wells Beam Area, from October 1990 to October 1993. 
The results of metals analyses in ground water monitoring wells at SLAC were erratic until 1993 (SLAC 1994). This historical data indicated widely varying concentrations of the same metals from quarter to quarter in the same well. In some wells the variation was on the order of several thousand ppb, which is far too great to be attributed to natural causes.

After careful evaluation of the problem, SLAC staff determined that the variability was caused by not filtering water samples prior to preserving them with acid. This resulted in dissolution of metallic solids in the ground water and consequently a much higher concentration of dissolved metal than naturally occurring in the ground water. The metals concentration would vary with the amount of solids contained in the sample.

Since sample filtration became a standard procedure for metals sampling at SIAC, the results have stabilized (Nuckolls, personal communication). However, the SWRCB staff has not seen this data as it was not included in the 1994 annual environmental monitoring report for SLAC. This data should be evaluated and a determination made as to whether hazardous metals have also leaked into ground water at SLAC.

TRITIUM

Low levels of tritium (less than $15,000 \mathrm{pCi} / 1$ ). have been found in one well (EXW-4) at SLAC, located on the eastern end of the IINAC. The maximum contaminant level for tritium in drinking water is $20,000 \mathrm{pCi} / \mathrm{L}$. SLAC staff conclude that the presence of tritium is the result of either activation of the ground water by the accelerator beam, or leaks from low conductivity water lines. SLAC reports that they will continue to monitor the well for 
tritium and will conduct further investigations if tritium levels develop a rising trend (SLAC, 1995). The SWRCB staff. concurs with this approach.

\subsection{SUMMARY, CONCLUSIONS, AND RECOMMENDATIONS}

\section{UST AREA}

A 3,500 gallon underground waste solvent tank located west of the Plant Maintenance Building leaked an unknown amount of solvents (predominantly methylene chloride) into ground water at SLAC. This occurred between 1965 and 1978. SWRCB staff were not able to obtain detailed information regarding the tank removal. The key information missing from the record includes:

1. The chemical nature of the 1800 gallons of "fluid" in the tank that was present when the tank was removed;

2. The concentrations of VoCs in soils that were removed during the initial excavation; and,

3. Any observations made by the contractor or government officials regarding details of the excavation, including the presence of free-phase solvents in the tank pit.

The above information is essential for a third party to estimate objectively the nature and extent of the waste solvent tank leak at SLAC. However, according to SLAC staff, this information does not exist. Thus, we can only speculate regarding the above three items.

The UST area is underlain by fractured Tertiary marine sandstones, siltstones, and claystones which form the eastern limb of an anticline. The eastern limb dips about $45^{\circ}$ to the 
east underneath the Plant Maintenance Building. Theoretically, free-phase liquids from the tank are likely to have migrated down the bedding planes of these rocks, and along fractures, thus spreading the solvents eastward underneath the Plant Maintenance Building.

However, data from borings drilled east of the excavation did not indicate any methylene chloride in soil samples. The data did show the presence of several hundred ppm of petroleum hydrocarbons in samples at about 10 feet below grade. The absence of methylene chloride in these samples is puzzling.

Nine ground water monitoring wells have been installed to investigate pollution from the tank leak, and one well (EM-1) was abandoned in 1986. This well very likely contained free phase solvents since a sample from this well contained greater than 450,000 ppb of methylene chloride. The well had to be abandoned when the tank excavation was increased to remove more polluted soil.

Periodic water level measurements from these wells indicate that the ground water gradient in the UST area rotated $180^{\circ}$ from northwest to southeast over a period of 18 months. The reason for this has not bee, determined, however, it could have been caused by local irrigation activities, broken sewer Iines, or influence from pumping of the LINAC excavation.

The highest concentrations of solvents in ground water (other than well EM-1) have been found in well EW-1. This well was installed when EM-1 was abandoned, and is located and screened in the tank excavation backfill gravel. Concentrations of total VoCs have decreased from about 230,000 ppb to less than 1,000 ppb, and methylene chloride is no longer detectable although it originally was at the highest concentration $(160,000 \mathrm{ppb})$ of 
solvents detected. This can be attributed to purging the well during sampling, volatilization from the permeable gravel backfill, and flushing of the tank pit by periodic recharge from rain and/or surface runoff.

As the ground water gradient rotated from northwest to the southeast, well MW-5 (located northeast of the tank) which originally did not contain any Vocs increased in Vocs up to about $160 \mathrm{ppb}$, then decreased in VoCs as the gradient shifted further. clearly, this can be attributed to the change in ground water gradient.

Only very low levels of vocs have been consistently detected in two other wells at the site, MW- 6 and MW-7.

Based on the above, the SWRCB staff recommend the following:

1. All documents relating to the excavation and removal of the underground waste solvent tank, including hazardous waste manifests which document transport and disposal of contaminated materials from the excavation should be reviewed to evaluate the magnitude of the leak. Most importantly, the chemical nature of the "fluid" that was removed from the tank just prior to excavation should be determined.

Based on this information, a determination should be made whether or not the polluted soil and fluid removed during and after tank removal can account for the bulk of solvents that leaked from the tank.

2. A model should be developed to explain the lack of methylene chloride in soil samples taken east of the tank excavation. since other constituents stored in the tank were found in 
these samples, it is puzzling why methylene chloride, which composed the bulk of solvents contained in the tank, is absent from these samples.

3. The rocks underlying the UST Area dip about $45^{\circ}$ to the east, and the ground water gradient has shifted to east/southeast. Given this, any free phase fluid that escaped removal during the tank excavation may have flowed eastward down bedding planes, and dissolved phase may have also migrated eastward. Therefore, a monitoring well should be placed east of the tank excavation and carefully screened with a short screened interval (< 10 feet) to capture the most likely flowpath of the solvents. A cluster of two wells screened at different intervals may be needed. This cluster of wells would help to make a final determination on whether free phase and/or dissolved phase, solvents have migrated downward.

4. Quarterly water level measurements should be taken in all of the wells in the UST area to track ground water gradient fluctuations.

5. An effort should be made to determine why the ground water gradient shifted to the southeast, and whether or not the LINAC is influencing ground water flow in the UST area. If it is determined that ground water drainage at the IINAC does influence ground water in the UST area, then an evaluation should be made as to whether the LINAC can be used to control (intercept) the solvent plume.

Clearly, the ground water flowing into the LINAC excavation should be sampled for vocs. If possible, the sample should be taken before the ground water enters the sump (s). 
Of the ten other wells that have been installed at SLAC for environmental investigations, four of them contain moderate to high levels of VOCs. These are wells MW-22, 24, and 25, in order of decreasing total VoCs. The sources of vocs in these wells has not yet been determined.

One well (EXW-4) at SLAC contains tritium consistently below the MCL for tritium in drinking water. The source of tritium in this well has not yet been confirmed.

Based on the above, the SWRCB recommends the following:

1. Determine the source of VOCs in wells $M W-22,24$, and 25 . Highest priority should be given to $M W-22$ in the plating shop area.

2. Continue with the current approach of monitoring well EXW-4 for tritium and conducting an investigation into the source if tritium shows an increasing trend.

3. Document ground water sampling for metals at SLAC after 1993, and based on this data, determine if metals have leaked into ground water. 


\subsection{REFERENCES}

Aetron, Blume, and Atkinson, 1965, Geologic Site Investigation for Stanford Linear Accelerator Center, Report to U.S. Atomic Energy Commission.

Ecology and Environment Inc., 1985, Soil and Ground water Investigation Stanford Linear Accelerator Center, Stanford California, Report to Stanford Linear Accelerator Center.

ESA Consultants, 1993a, Stanford Linear Accelerator Center -Preliminary Assessment, Report to Stanford Linear Accelerator Center, Environment, Safety and Health Division.

1993b, Stanford Linear Accelerator Center -- Soil Gas Survey, Report to Stanford Linear Accelerator Center, Environment, Safety and Health Division.

1994a, Stanford Linear Accelerator Center -Hydrogeologic Review, Report to Stanford Linear Accelerator Center, Environment, Safety and Health Division.

1994b, Stanford Linear Accelerator Center - - Annual Well Inspection and Maintenance Program, Report to Stanford Linear Accelerator Center, Environment, Safety and Health Division.

DOE (U.S. Department of Energy), 1988, Environmental Survey Preliminary Report, Stanford Linear Accelerator Center, Environment, Safety and Health office of Environmental Audit.

Ground water Technology, 1987, Subsurface Hydrocarbon Investigation Stanford Linear Accelerator Center, Report to Stanford Linear ACC '-rator Center.

SLAC (Stanford Linear Accelerator Center), 1993, Annual Environmental Monitoring Report, January - December 1990, SLAC Environmental, Safety, and Health Division.

, 1994, Annual Environmental Monitoring Report, January - December 1993, SLAC Environmental, Safety, and Health Division.

1995, Annual Environmental Monitoring Report; January - December 1994, SLAC Environmental, Safety, and Health Division.

1995, Draft Workplan for the Remedial Investigation of the Former Solvent Underground Storage Tank, Environmental, Safety, and Health Division. 
1995, Fourth Quarter Monitoring Report for.

Monitoring Wells at the site of the Former Leaking Underground Storage Tank, Environmental, Safety, and Health Division.

Sokol, D., 1963, Hydrogeology of the San Francisquito Creek Basin, San Mateo and Santa Clara Counties, Phd Dissertation, Stanford University, California. 


\section{APPENDIX $6.0 \bar{A}$ \\ REPORT ON AN AQUIEER TEST AT STANEORD IINEAR ACCELERATOR CENTER}

\section{DESCRIPTION}

Under the aegis of the Agreement in Principle (AIP) program, the State Water Resources Control Board, Division of Clean Water Programs conducted an aquifer test on February 2, 1996, at Stanford Linear Accelerator. A description of the test, and the test results, are presented below.

According to a draft workplan dated January 3, 1996 (attached) the proposed aquifer test was to be a pumping test of well MW-7, proceeding at about 1 gallon per minute for 8 hours. This pumping test was attempted twice in the early morning of Eebruary 2. During the first test the well was pumped for about 17 minutes when it went dry. The discharge rate varied from about $.5 \mathrm{gpm}$ initially, to $1.8 \mathrm{gpm}$ when flow ceased. Due to the fact that the work crew did not have a flow meter available to accurately measure flow, it had to be measured via calibrated buckets. Additionally, there was some confusion among the crew as to what level (in hertz) to set the pump controller in order to achieve 1 gpm. Because of these difficulties we ended up pumping the well dry during the first test.

The second pumping test began at 9 am shortly after the first test. Water levels had not completely recovered and pumping began with about 6 feet of drawdown remaining in the well. The pumping rate was limited to a maximum of $.8 \mathrm{gpm}$ during this test. Drawdown appeared to stabilize at a pumping rate between .025 and $0.8 \mathrm{gpm}$, however, we were not able to maintain the proper pumping rate to keep from dewatering the well again. After pumping MW-7 dry twice, we decided to shelve the pumping test and salvage the day by conducting a slug-out aquifer test.

The slug-out test consisted of dewatering $\mathrm{MW}-7$ once again, and monitoring the rate of water level recovery in the well. Water level recovery data can be used to calculate the hydraulic conductivity of the formation immediately surrounding the well. Water levels were measured for 195 minutes. Initially we took measurements continuously, then at 1 minute intervals, 5 minute intervals, 10 minute intervals and finally 15 minute intervals.

RESULTS

The results of the slug-out test were calculated via AQTESOLV, which is a DOS based computer program for analyzing various aquifer tests. We used the Bouwer-Rice method for unconfined aquifers, and used a saturated thickness value of $100 \mathrm{ft}$. (actual value unknown). However, we found that varying the saturated thickness did not significantly alter the calculated hydraulic 
conductivity, thus we are confident in the results obtained using $100 \mathrm{ft}$. Figure 1 shows the results of the aquifer test.

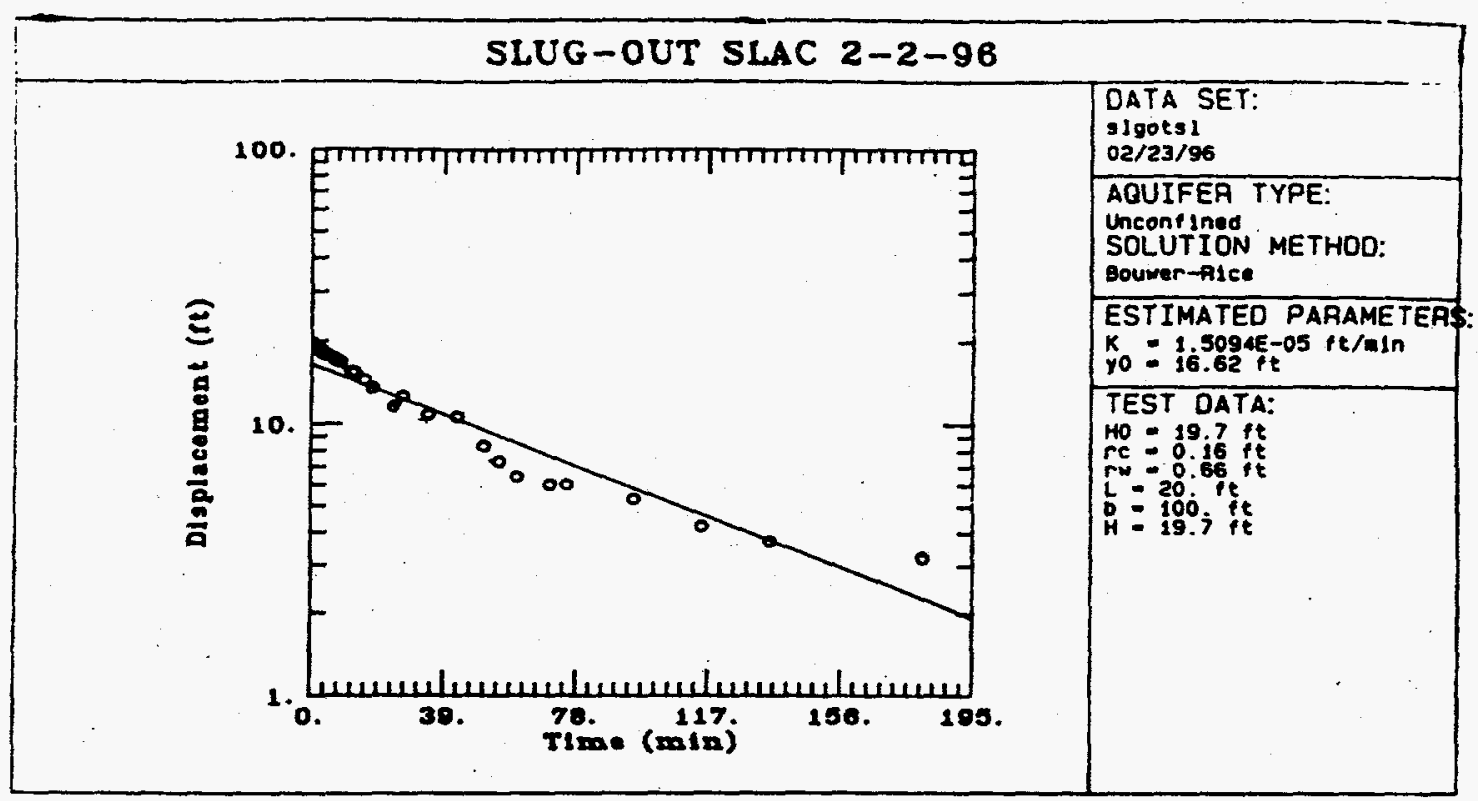

Figure 1. Graphical and numerical results of an aquifer test at test at SLAC.

AQTESOLV presents hydraulic conductivity in $\mathrm{ft} / \mathrm{min}$, and converting that to $\mathrm{cm} / \mathrm{sec}$ only divides the value in half. Hydraulic conductivity in the range of $10 e-5 \mathrm{~cm} / \mathrm{sec}$ is commensurate with previous results from wells screened in Miocene bedrock at SLAC.

\section{COMPOSITION/DISPOSITION OE DISCHARGE WATER}

During the two attempted pumping tests, and the slug-out test, approximately 2.5 well volumes (about 56 gallons) were extracted from $M W-7$ and discharged into the holding tank. Additionally, about 150 to 200 gallons of tap water from the site were also discharged into the tank while testing the pump, and as a result of cleanup operations.

Since less than a third of the holding tank was used, we decided to haul the water back to sacramento, test it, and then dispose of it in an appropriate manner depending on the test results. The water was analyzed by EPA methods $601 / 602$ modified and the results are attached. Total Volatile Organic Compounds (VOCs) were detected at $27 \mathrm{ppb}$. However, most of these were trihalomethanes. Trihalomethanes commonly form in water that has been chlorinated to kill bacteria. Thus the tap water from the site contributed most of the VOCs. Those VOCs that can be directly attributed to the well water (1,1-DCA, TCE, PCE) only amounted to about $2 \mathrm{ppb}$.

Given this, the discharge water will be sprayed over the asphalt at the Regional Water Boards Sacramento offsite storage area. 


\section{DRAFT WORKPIAN FOR A MONITORING WELL PUMPING TEST AT STANFORD LINEAR ACCELERATOR CENTER}

Under the aegis of the Agreement in Principle (AIP) program, the State Water Resources Control Board, Division of Clean Water Programs, will conduct a step-drawdown pumping test on a monitoring well at Stanford Linear Accelerator Center (SLAC). The test will be done on January 11 and 12, 1995.

The purpose of this pumping test is to gain more information on the hydrogeologic system that underlies an area impacted by a leaking underground waste solvent tank. The tank was found to be leaking in 1983, and subsequently removed. Since the tank removal, nine monitoring wells have been installed (one abandoned in 1986) to define the extent of pollution from the leaking tank. However, the geology of the area is a complex system of folded and fractured sedimentary rocks and ground water movement in the area is, to date, poorly understood.

Slug tests (slug-in) have been done on some of the monitoring wells, but these only provided hydrogeologic information in the immediate vicinity of the well. A step-drawdown pumping test that lasts for several hours will stress the system and provide an estimation of formation permeability.

The Regional Water Board (5S) will supply all of the equipment needed. This includes use of a $2 "$ Grundfos pump, 2 generators, a sampling truck, a 750 gallon holding tank, and a support vehicle with accessory equipment. Both State Water Board and Regional Water Board staff will conduct the test and calculate the results. SLAC staff will provide assistance where needed. State Water Board staff will then prepare a report on the test to be included in the final AIP report for SLAC.

The pumping test wi?" he done on well MW-7 which is located south of the former leaking tank. The current ground water gradient is east/southeast. Well $\mathrm{MW}-7$ has historically contained very low levels of VoCs (less than $25 \mathrm{ppb}$ ). Because of this, discharge from the pumping test can be disposed of in the SLAC sewer system under its current permit.

Given the estimated permeability of the rocks underlying the site (based on slug-tests), and the construction of $M W-7$, we estimate that the pumping test will proceed at about 1 gallon a minute (gpm) (measured with 5 gallon buckets) for about 8 hours. This will generate 480 gallons of wastewater. A rate of $1.5 \mathrm{gpm}$ for eight hours can be done without overfilling the holding tank.

Prior to and during the pumping test, ground water levels will be measured in the pumping well and surrounding wells (MW-2, MW-3, $M W-4, M W-5, M W-6, E W-1)$. The preliminary measurements will establish a baseline for ground water levels which can then be included in the pumping test calculations for greater accuracy. 
Lab Number:

Field I.D:

Sampled Date:

Received Date:

Tested Date:

Task Code:

sampler:

3866
$020696-1 D I D$
$02 / 06 / 96$
$02 / 06 / 96$
$02 / 07 / 96$
$164-08$
D.I. Daniels'

COMPOUND ANALYZED

Bromobenzene

Bromochloromethane

Bromodichloromethane

Bromoform

Bromomethane

Carbon tetrachloride

Chlorobenzene

Chloroethane

Chloroform

Chloromethane

2 -Chlorotoluene

4-Chlorotoluene

Dibromochloromet hane

1, 2-Dibromo-3-Chloropropane

Dibromomethane

1,2-Dibromoethane

1,2-Dichlorobenzene

1,3-Dichlorobenzene

1,4-Dichlorobenzene

Dichlorodifloromethane

1,1-Dichloroethane

1,2-Dichloroethane

1, 1-Dichloroethylene

cis-1,2-Dichloroethylene

trans-1,2-Dichloroethylene

1,2-Dichloropropane

1,3-Dichloropropane

2,2-D1chloropropane

1,1-Dichloropropylene

cis-1,3-Dichloropropylene

trans - 1, 3-Dichloropropylene

Hexachlorobutadiene

Methylene chloride

$1,1,2,2$-Tetrachloroethane

$1,1,2,2$-Tetrachloroethane

Tetrachloroethylene

1,2,3-Trichlorobenzene

$1,2,4$-Trichlorobenzene

$1,1,1-\mathrm{Tr} 1 \mathrm{chl}$ oroechane

$1,1,2$-Tr1 chloroethane

Trichloroethylene

Trichlorof luoromethane

1,2,3-Trichloropropane

vinyl chloride

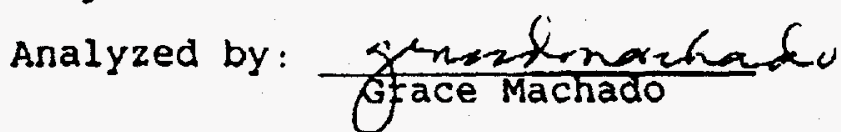

Sample Location:

Sample Type:

Preservative:

Holding Time (day):

Exeracted by ETA Merhod. 5030

$\begin{array}{ll}\text { Extracted by BPA Method: } & 5030 \\ \text { Analyzed by BPA Method: } & 601 \mathrm{M}\end{array}$

Sample Amount:
$5.000 \mathrm{ml}$

MW - 7

Water

None

7.0

\section{DETECTION LIMIT}

(ug/1)

0.1

0.1

0.1

0.1

0.1

0.1

0.1

0.1

0.1

0.1

0.1

0.1

0.1

0.1

0.1

0.1

0.1

0.1

0.1

0.1

0.1

0.1

0.1

0.1

0.1

0.1

0.1

0.1

0.1

0.1

0.1

0.1

0.2

0.1

0.1

0.1

0.1

0.1

0.1

0.1

0.1

0.1

0.1

0.2

Checked by:
CONCENTRATION

(ug/1)

ND

ND

3.4

5.1

ND

ND

0.5

ND

6.0

ND

0.5

ND

4. 8

ND

3.4

ND

ND

ND

ND

ND

1.5

ND

ND

ND

ND

ND

ND

ND

ND

ND

ND

ND

ND

ND

ND

ND

ND

ND

ND

ND

0.3

ND

ND

ND 
JRNIA REOTONAL MATER QURLITY CONTROL BOARD Routior Road

framento, CA 95827-3098

CENTRAL VALLEY REGION

Phone: (916) 255-3000

AT88 Phone:8-255-3000

Lab Number:

Field I.D:

Sampled Date:

Recelved Date:

Tested Date:

Task Code:

sampler:

3867
$020696-1 D I D$
$02 / 06 / 96$
$02 / 06 / 96$
$02 / 07 / 96$
$164-08$
D.I. Daniels

COMPOUND

ANALYZED

Benzene

Bromobenzene

n-Butylbenzene

aec-Butylbenzene

tert-Butylbenzene

Chlorobenzene

2-Chlorotoluene

4-Chlorotoluene

1,2-Dichlorobenzene

1,3-Dichlorobenzene

1.4-Dichlorobenzene

Dichlorodif loromethane

1, 2-Dichloroethylene

cis-1,2-Dichloroethylene

trans-1,2-Dichloroet hylene

1, 1-Dichloropropylene

cis-1,3-Dichloropropylene

trans-i, 3-Dichloropropylene

Echylbenzene

Hexachlorobutadiene

p-Isopropyl coluene

Naphthalene

iso-Propylbenzene

n-Propyibenzene

styrene

Toluene

Tetrachloroethylene

1,2,3-Trichlorobenzene

1,2,4-Trichlorobenzene

Trichloroethylene

$1,2,4-T x$ imethylbenzens

1, 3,5-Trimethylbenzene

vinyl chloride

m-xylene

o-xylene

p-xylene

\section{Sample Location:}

Sample Type:

Preservative :

Holding Time (day):

Bxtracted by BPA Method: 5030

Analyzed by BPA Method: 602M

Sample Amount:
$5.000 \mathrm{mI}$

MW-7

Water

None

7.0
CONCBNTRATION

(ug/ I)

0.1

ND

ND

ND

ND

0.5

0.5

ND

ND

ND

ND

ND

ND

ND

ND

ND

ND

ND

ND

ND

ND

Trace

ND

ND

ND

0.1

ND

ND

ND

0.3

ND

ND

ND

Trace

Trace

Trace
Analyzed by:

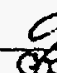

Gantarata qua machado
Checked by: Maytter 
State Water Resources Control Board 1995 AIP Summary Report

ENERGY TECHNOLOGY ENGINEERING CENTER

Prepared For:

UNITED STATES DEPARTMENT OF ENERGY OAKLAND OPERATIONS

\section{Prepared By:}

GIL TORRES

SENIOR ENGINEERING GEOLOGIST

STATE WATER RESOURCES CONTROL BOARD

DIVISION OF CLEAN WATER PROGRAMS

SACRAMENTO, CALIFORNIA

MARCH 1996 


\subsection{ENERGY TECHNOLOGY ENGINEERING CENTER}

\subsection{INTRODUCTION}

Primarily on the basis of 1990 through 1994 documentation that has been obtained for review by state water Resources Control Board's (SWRCB) AIP Program staff, the following is a summary assessment of ongoing affected ground water characterization and remediation-related activities within and adjacent to the Area IV portion of the Santa Susana Field Laboratory (SSFL). The SSFL facility is located in the Simi Hills of eastexn Ventura County as shown on Figure 1 .

In addition to presenting general findings on current ground water monitoring system adequacy, conclusions and recommendations are intended to provide a basis for possible modification of its design for further site characterization as deemed appropriate by the U.S. Department of Energy (DOE). Subsurface characterization modifications are necessary to facilitate collecting more definitive data on hydrogeologic and related water quality factors that are the fundamental criteria for designing and implementing optimal measures to remediate contaminated ground water.

The 290-acre Area IV includes the DOE's leased (with option to buy) 90-acre Energy Technology Engineering center (ETEC) which is operated by Rockwell International Corporation's Rocketdyne Division (Rockwel1). In addition to Area IV, the 2,700-acre SSFL facility is further subdivided into Rockwell-owned and -operated Area I, Area III, and the "Buffer Zone" portion shown on Figure 2. Although also operated by Rockwel1, Area II is owned by the U.S. National Aeronautics and Space Administration. 
Land adjoining the northern property Iine of Area IV is owned by the Brandeis-Bardin Institute (BBI). Area IV's western boundary abuts another parcel that also is under private ownership.

\section{2 BACKGROUND}

Rockwell's predecessor, North American Aviation, Inc., acquired the SSFL property during the late 1940s primarily for rocket engine testing. In 1955, its Atomics International Division (AI) was formed and Area IV was dedicated for nuclear reactor development and test research. During the latter part of the 1950s and early 1960s, AI conducted research on the: 1) sodium Reactor Experiment nuclear power plant development, and 2) Systems for Nuclear Auxiliary Power (SNAP) space power development using sodium and potassium as coolants. ETEC was established thereafter as a DOE laboratory for the development of liquid metal heat transfer systems to support a Liquid Metal Fast Breeder Reactor program. In 1966, DOE-sponsored research work commenced on liquid metals (primarily sodium) as heat transfer media for advanced nuclear reactors. All nuclear reactor research was terminated in the mid-1970s. The most recent ETEC activities have included the testing of non-nuclear systems and components for use in energy power conversion and liquid metal development programs.

Seventeen mostly unsealed, cased, partially cased, and uncased cable tool wells, varying from 203-to 2,304-feet in depth, were installed during the late $1940 \mathrm{~s}$ to mid-1950s to meet the SSFL water supply demands. On the basis of a program that was implemented by Rockwell in 1984, ground water samples from these wells were analyzed for organics solvents content. It was found that trichloroethylene (TCE) and other chlorinated compounds were present in ground water at some of the supply wells. Upon reporting this information to the Los Angeles Regional Water 
Quality control Board (RWQCB), Rockwell initiated a facility-wide Phase I hydrogeologic and water quality conditions investigation in December 1984. Phase I entailed installing 11 "shallow" wells near a surface impoundment in Area III.

RWQCB's site characterization oversight responsibilities continued until July 1989 when U.S. EPA designated Cal-EPA's Department of Toxics Substances Control (DTSC) as the lead regulatory agency for the SSFL.

BRIEF CONTAMINANT CHARACTERIZATION HISTORY IN AREA IV

During three ensuing SSFL-wide investigation phases conducted from mid-1985 to early 1987, one "deep" and four "shallow" monitoring wells were installed within Area IV.

Prompted by a DOE Order, the aforementioned deep monitoring well was sited and constructed for the purpose of evaluating whether hazardous substances had migrated to underlying ground water from that which potentially existed at a former "landfill" or "temporary drum storage area" near Building 59. Subsequently in 1987, hazardous substance occurrence also was reported at the Building 886 Former Sodium Disposal Facility area.

Pursuant to a May 1988 DOE environmental survey (Mukherjee, 1994), the following 10 Area IV sites (shown on Figure 3) were identified as known or potential sources of soil and/or ground water pollution: 1) Building 886, Former Sodium Disposal Facility, 2) Building 59 Area, Former SNAP Reactor Facility, 3) Building 21/22; Radioactive Materials Disposal Facility (RMDF) Leachfield Area, 4) old Conservation Yard, 5) Building 56 Landfill Area, 6) ESADA Chemical storage Yard, 7) Building 100 Trench Area, 8) Southeast Drum Storage Area, 


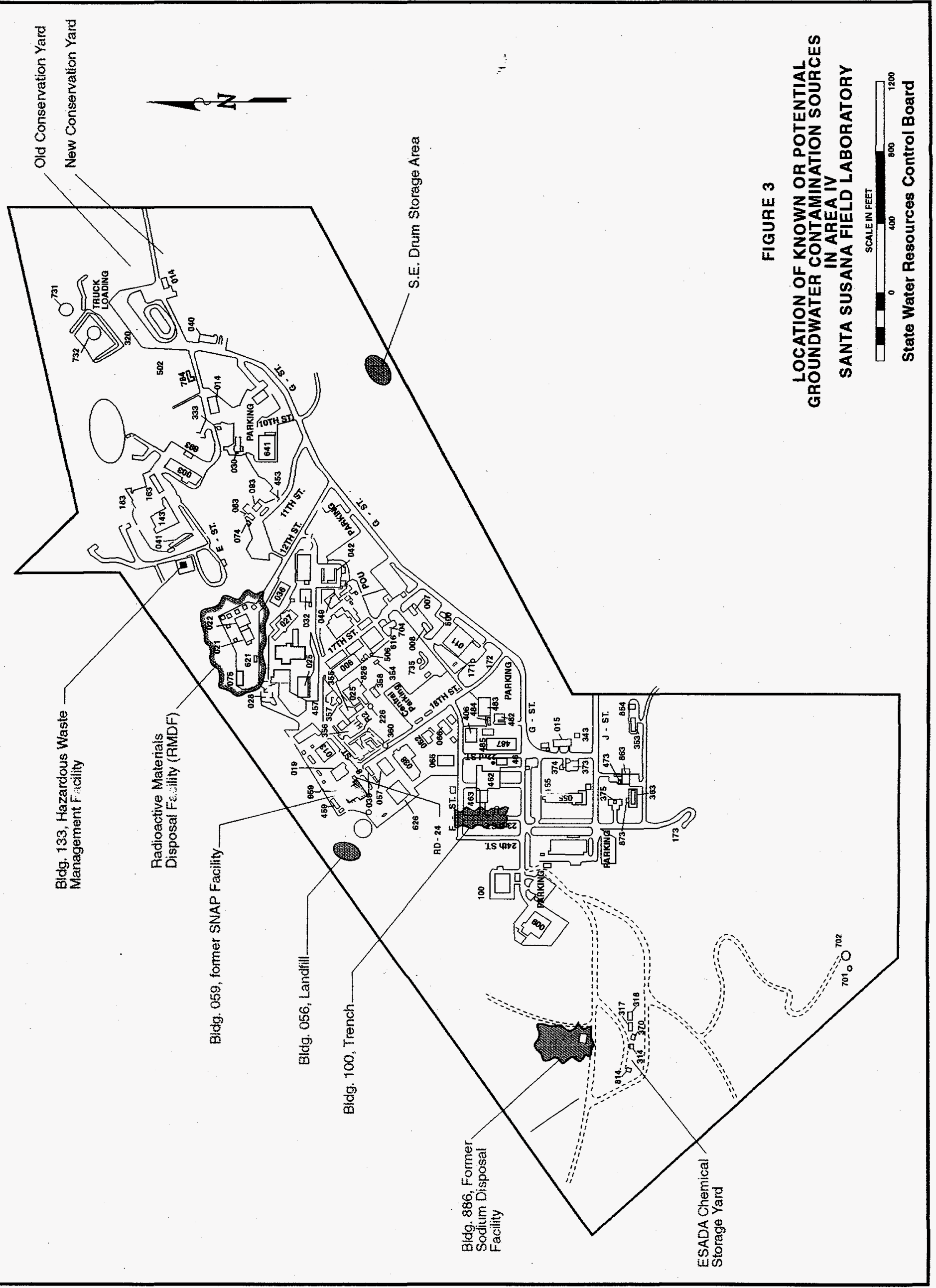


9) New Conservation Yard, and 10) Building 133, Hazardous Waste Management Facility.

During 1988 and 1989, an additional six shallow and 17 deep monitoring wells were installed to further characterize hydrogeologic and ground water conditions in Area IV. At that time, volatile organic compounds (VOCs) were found in ground water at one shallow well in the RMDF Area. Also, Vocs in deepwell ground water were detected primarily in the vicinities of the: 1) Former Sodium Disposal Facility, 2) Buildings 56/59 Area, 3) RMDF Area, and 4) Old Conservation Yard.

During a July to September 1991 investigation, each of two offsite drilling locations nearby and to the north were selected for the installation of one 3-well cluster to monitor ground water at different depths. One of these sites was to be in the then anticipated hydraulically downgradient direction from the Former Sodium Disposal Facility and the other similarly situated with respect to the RMDF Area. The purpose of both clusters was to continue the process of evaluating the lateral and vertical extent of the earlier-reported ground water pollution at those sites. VoCs (mainly TCE) were found in the " $A$ " and " $B$ " wells of each cluster.

Largely as part of an SSFL-wide 1992 Interim Well Construction Plan that was implemented during 1993-94, additional ground water monitoring installations within Area IV included: 1) a deep well to evaluate subsurface conditions south of the Former sodium Disposal Facility at the southern margin of Burro Flats, 2) a shallow well, a deep three-well cluster, and two additional deep wells in the Former Sodium Disposal Facility area, and 3) another on-site deep well north of the RMDF Area. During this two-year period, the following deep wells also were installed in the BBI property portion that is north from Area IV: 1) another 
deep well to further evaluate subsurface conditions laterally and vertically from the Former Sodium Disposal Facility, and

2) another deep three-well cluster to evaluate subsurface conditions at a site to the north and more distant from Area IV. Significant VOC concentrations in shallow- and deep-well ground water were found only within the Former Sodium Disposal Facility. Through 1994 (and as of June 1995), a total of 10 shallow and 23 deep monitoring wells were installed within Area IV and the 10 previously-mentioned off-site deep wells. One shallow well at the old Conservation Yard was destroyed in July 1989.

SURFICIAL EVALUATION OF KNOWN OR POTENTIAL GROUND WATER POLLUTION SOURCES IN AREA IV

In response to DOE's 1988 identification of the known or potential sources in Area IV, Rockwell (Rocketdyne, 1992) performed corresponding evaluative work and reported contaminant occurrence as follows on a site-by-site basis:

1. Building 886, Former Sodium Disposal Facility -Analysis of soil samples collected at 22 trenches in 1988 indicated the presence of Vocs, metals, petroleum hydrocarbons, polychlorinated biphenyls, and other organic compounds.

2. Building 59 Area, Former SNAP Reactor Facility -- In 1988, tritium was found to be present in building basement water. At that time, water in a french drain surrounding this building contained tritium and VOCs such as TCE and perchloroethylene (PCE).

3. RMDF Leachfield Area -- In 1989, soil sampled within this former leachfield area contained toluene, xylenes, methyl ethyl ketone (MEK), methylene chloride, ethylbenzene, various phthalates, and gross beta radioactivity above background levels. The RMDF includes Buildings $21,22,75,621,665,668$, and a pond 
where surface drainage from the immediate area was collected. High and/or low level radioactive materials were handled/stored in the buildings.

4. Old Conservation Yard -- During the 1960s and 1970s, this yard was used for drum (unknown contents) and equipment storage. An underground tank and approximately 100 cubic yards of soil were removed from the northwestern part of the yard in 1989. Soil samples (from less than a 5-foot depth) showed trace levels of toluene, acetone, 2-butanone, xylenes, and methylene chloride. A 4,000 milligram per $\mathrm{kilogram}(\mathrm{mg} / \mathrm{kg})$ petroleum hydrocarbon concentration was detected in a soil sample obtained in the vicinity of the former underground tank.

5. Building 56 Landfill Area - In 1987, a 9-foot deep landfill soil sample only showed a $500 \mathrm{mg} / \mathrm{kg}$ oil and grease concentration. Moreover, one of three soil samples collected at an adjacent drainage ravine also was found to have $1,100 \mathrm{mg} / \mathrm{kg}$ oil and grease. Another of those three only contained $0.9 \mathrm{mg} / \mathrm{kg}$ trichlorofluoromethane.

6. ESADA Chemical Storage Yard -- Approximately 50 to 100 drums reportedly containing alcohols or sodium were stored in this yard in the 19\%us. Sodium and potassium in soil samples were found only at background concentrations in 1989. Only trace amounts of hydrocarbons were detected.

7. Building 100 Trench Area -- This trench was used for construction debris and possible hazardous substances disposal in the 1960s. In 1989, four soil samples collected at two (less than 5-foot-deep) trenches only demonstrated petroleum hydrocarbon concentrations of no more than $400 \mathrm{mg} / \mathrm{kg}$. 
8. Southeast Drum Storage Area - In accordance with aerial photos reviewed by DOE, approximately 50 drums were stored in this area in the 1960s. Soil sampled at three (less than 5-foot deep) borings did not show any pollution in 1989 .

9. New Conservation Yard -- This area was a drum and equipment storage area during the late 1970s and 1980s. Soil samples gathered at two borings (less than 5 feet deep) contained no more than $11 \mathrm{mg} / \mathrm{kg}$ toluene and petroleum hydrocarbon content of less than one $\mathrm{mg} / \mathrm{kg}$.

10. Building 133, Hazardous Waste Management Facility -- In 1989, trace amounts of acetone, MEK, and xylenes were detected in four soil samples collected from a trench. Also, a sample collected from an underground-tank-excavation soil pile contained up to a maximum $6,900 \mathrm{mg} / \mathrm{kg}$ sodium and a corresponding $11.8 \mathrm{pH}$. Otherwise, another soil sample from a drain-pipe trench area showed gross beta radioactivity that exceeded background levels.

BRIEF SUMMARY OF SIGNIFICANT GROUND WATER POLLUTION IN THE VICINITY OF AREA IV

The areal extent of significant Area IV-related pollution has been generally considered as that where TC predominates in deepwell ground water at concentrations exceeding 5 micrograms per liter (ug/I). Such pollution was first detected in 1989 in the respective vicinities of the: 1) Building 886 , Former Sodium Disposal Facility, 2) Building 59 Area, Former SNAP Reactor. Facility, and 3) RMDF Area. Furthermore, as of late 1994 (GWRC, 1995), contaminated ground water (that has an apparent Area II source) exhibiting those TCE concentrations was found to underlie the northeasternmost tip of Area IV. Except for the Building 59 Area where subsurface characterization of contaminant occurrence has been minimal, the aforementioned TCE-contaminated 
ground water at the other three locales has been detected at offsite deep wells within the BBI property.

\subsection{HYDROGEOLOGIC CONSIDERATIONS}

The adequacy or effectiveness of the existing Area IV subsurface monitoring system can be ascertained only if there is a thorough understanding of the geologic/hydrogeologic framework within which there is contaminated and uncontaminated ground water occurrence and movement. The current framework, as understood by SWRCB AIP staff, is largely based on 1990 through 1994 information provided by Rockwell.

GEOLOGIC SETTING

SSFL Area IV primarily encompasses most of the Burro Flats portion of the northeast-southwest trending Simi Hills. Burro Flats surface runoff is to the south-southeast where it merges with that from Area III, Area II, and the Buffer Zone to form part of the Bell Canyon drainage. As shown on the Figure 4 areal geology of the Area IV vicinity, the principal surficiallyexposed geologic units (from oldest to youngest) are the:

1) Chatsworth Formation of Cretaceous age, 2) Martinez Formation of Tertiary age, and 3) unnamed Alluvium of Quaternary age (Mukherjee, 1994).

Locally, the Chatsworth Formation is comprised of northwesterlydipping (at approximately 30 degrees) massive and fractured sandstone beds that are interlayered by siltstones and mudstones. This formation forms the predominant rock exposures in the SSFL vicinity. Locally, its thickness may be several thousand feet.

Northwest-dipping sandstone and shale beds (of locally unknown thickness) mainly comprise the Martinez Formation. It is exposed 


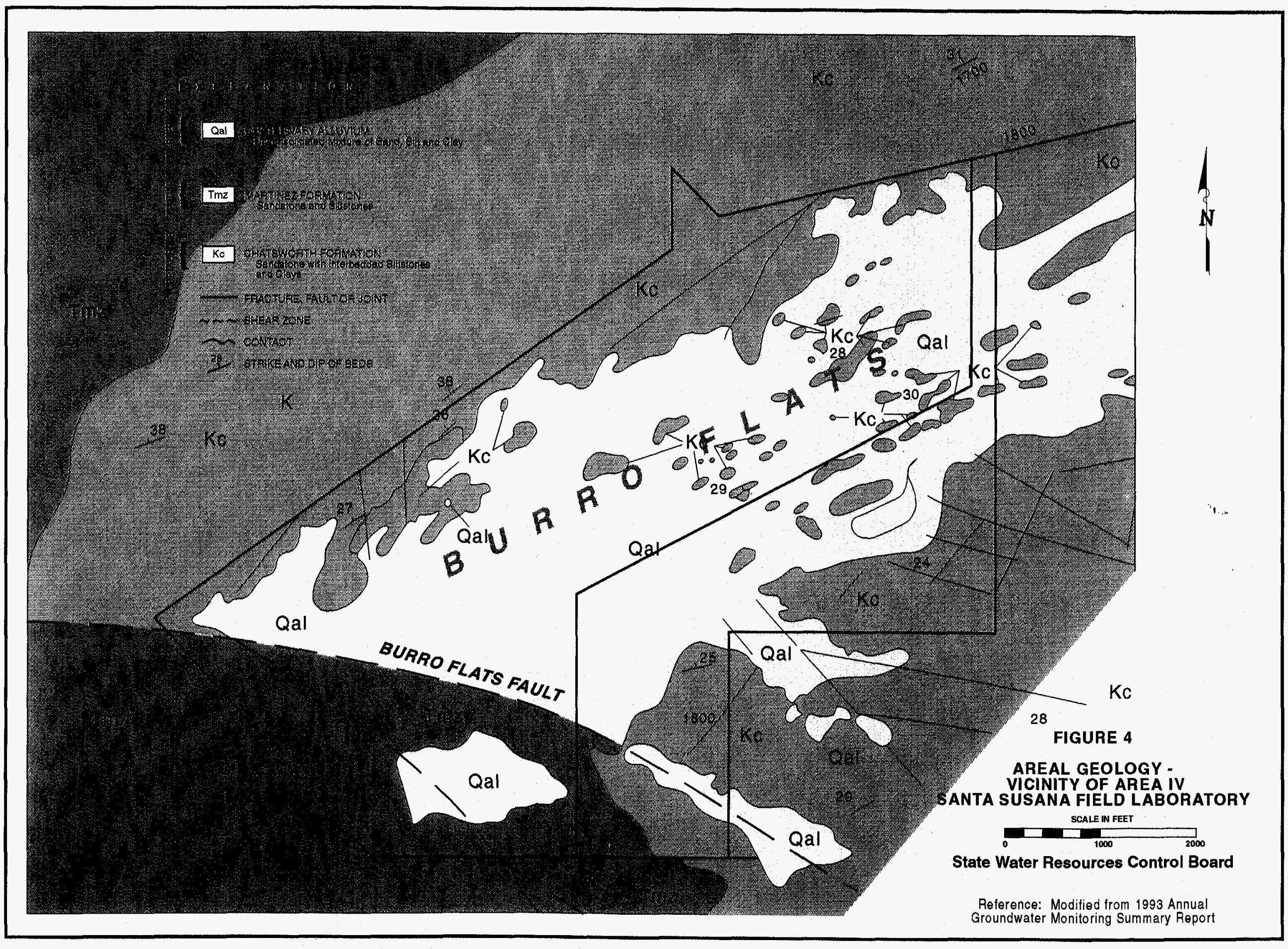


natural occurrence or source of ground water, 2) recharge of ground water, 3) hydraulic gradient(s), including movement and discharge of ground water, and 4) fluctuation of ground water levels.

\section{Source of Ground water}

The principal sustainable source of ground water that has been reported within Area IV is the Chatsworth Formation. WS-7, a 700-foot deep water supply well, was designed and constructed to produce Chatsworth ground water from about its lowermost 500-foot depth interval.

In addition to known production at other SSFL water supply wells, Chatsworth ground water is produced off-site at BBI wells OS $-1,-2,-3,-4$, and -5 . Figure 5 shows the locations of these and other wells that have been used for monitoring purposes by Rockwell.

\section{Recharge of Ground Water}

In Area IV, precipitation is the main source of recharge to ground water that occurs within the Shallow Zone and Chatsworth Formation. According to Rockwell (Mukherjee, 1994), recharge of the Chatsworth is primarily through its fractures and other rock openings. If this is so, it is unclear whether recharge along Area IV's "ground water divide" (discussed below) is associated with a fracture/rock opening alignment that has not been identified by Rockwell.

Movement and Discharge of Ground Water

Water that has infiltrated the Shallow Zone and Chatsworth Formation moves from areas of higher ground water elevations to 


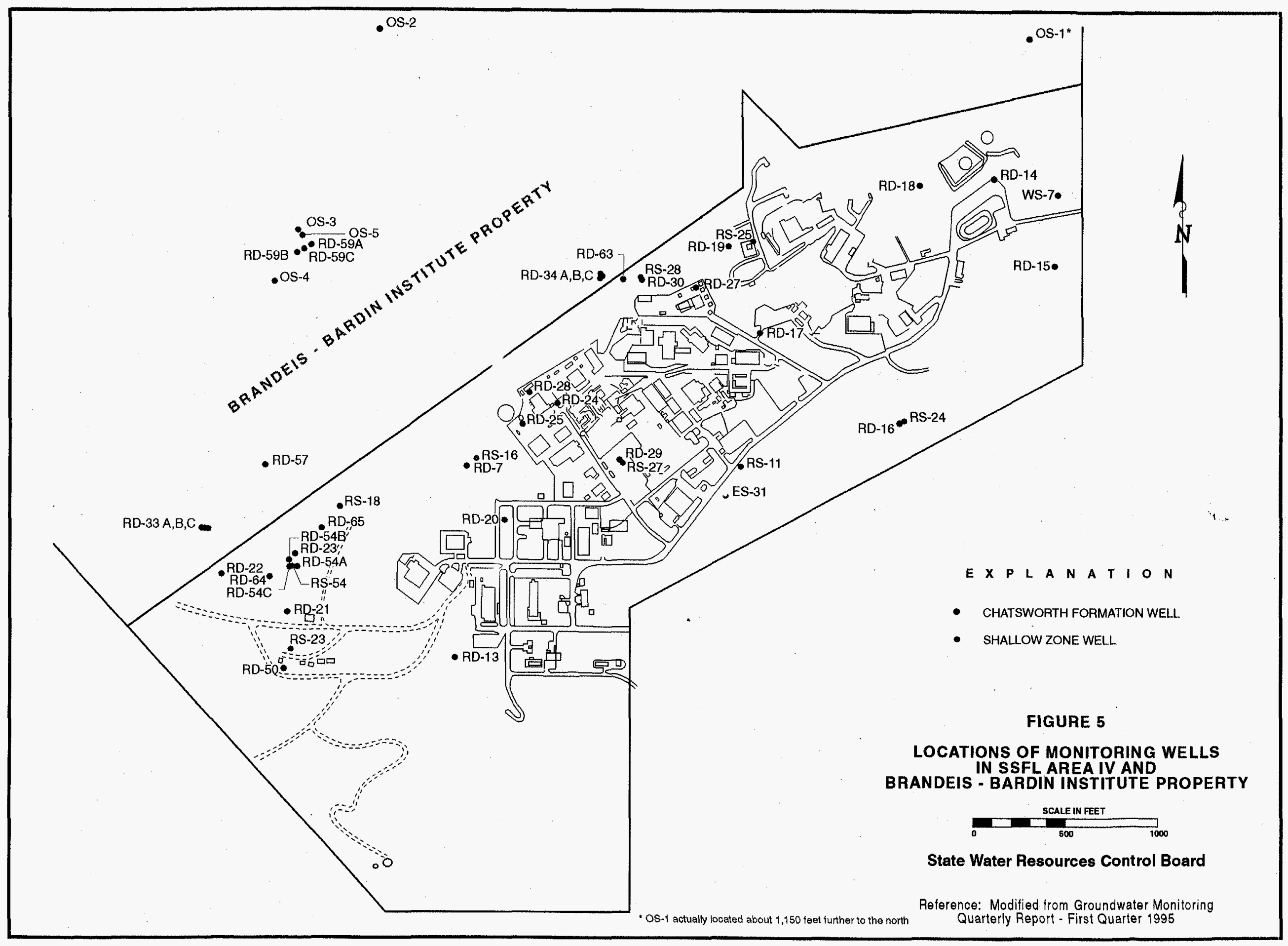


those of lower elevations (or areas of higher hydraulic head to those of lower head). Where there is currently no reported SSFL or any other ground water supply well pumpage influence, ground water moves down the hydraulic gradient and discharges at the lowest elevations of each system. Excess ground water from either system may surface at springs.

\section{Shallow zone}

Available information is insufficient to show seasonal/perennial ground water level elevation contour and ground water flow direction(s) within the Shallow Zone in Area IV. However, it has been reported (Mukherjee, 1994) that Shallow Zone ground water in Area IV: 1) may move laterally to areas of discharge or downward into the underlying Chatsworth, and/or 2) moves north from the Burro Flats Fault along the alluvium-Chatsworth contact and downward through Chatsworth fractures. On the other hand, this report also indicates that shallow zone ground water movement is in the direction of lower topographic elevations and that most of it is in canyon areas where it parallels surface flows. Surface drainage from Burro Flats is to the south-southeast as previously indicated. Therefore, it is likely that there is shallow zone ground water flow to the south from some if not all of the identified pollution sources.

\section{Chatsworth Formation}

Rockwell has indicated that Chatsworth Formation ground water primarily occurs and moves within rock fractures and other rock openings (Mukherjee, 1994) and that its flow direction appears to be to the northwest from the Former Sodium Disposal Facility (GWRC, 1995b). Based on information collected at individual monitoring wells, Rockwell has further reported (Mukherjee, 1994) that Chatsworth Formation ground water (that moves along 
flowpaths apparently formed by laterally- and vertically-varying rock opening interconnections) reflects unconfined (water table or nonpressure) and confined (artesian or pressure) conditions. Rockwell has suggested (Mukherjee, 1994) also that those Area IV rock opening interconnections/flowpaths exhibit high hydraulic conductivities or are able to transmit significant quantities of Chatsworth Formation ground water.

Rockwell has not presented definitive information on localized interconnected rock opening-controlled flowpath directions from Area IV to off-site areas. Additionally, depending on monitoring well design and location, water levels in the shallower Chatsworth well depth intervals seem to mainly show water table conditions while some of the deeper intervals appear to represent confined pressure conditions.

FLUCTUATION OF GROUND WATER LEVELS

Rockwell commenced measuring water levels at Area IV monitoring wells during the late 1980 s to observe seasonal ground water elevation fluctuations. The corresponding available information indicates that since December 1989, Chatsworth Formation water level elevations have essentially remained the same as those represented by the November 1994 contours (lines of equal ground water elevation) shown on Figure 6 .

The dominant hydraulic feature on Figure 6 is the northeastsouthwest trending "ground water divide" that is depicted by the 1,775- and 1,800-foot above mean sea level contour lines. This divide, which has prevailed since December 1989 (GWRC,1990), governs the "apparent" directions (to the northwest onto BBI property and to the southeast onto SSFL Area II) of ground water flow from Area IV. Even though the divide is not fully delineated/extended to the westernmost extremity of Area IV, the . 
water level data presented on Figure 6 indicate also that there is probable southerly Chatsworth ground water flow in the direction of the Burro Flats Fault and/or the Martinez Formation vicinity of Area IV.

Rockwell has asserted (Mukherjee, 1994) that Chatsworth Formation ground water level changes (or decline) have been significantly affected by extractions at SSFI water supply wells (located other than in Area IV). However, available information (GWRC, 1995a) indicates that water levels have not been influenced by or have declined due to such pumpage in the vicinity of Area IV's water supply well WS-7. There was a net water level elevation increase of about 16 feet at WS-7 from the early 1950 s through 1994 . Moreover, the presence of the ground water divide (or hydraulic ridge) in conjunction with available Chatsworth Formation water level data obtained at monitoring wells suggest that ongoing SSFL-wide extractions have not significantly influenced Area IV ground water conditions in recent years.

STABLE ISOTOPE INVESTIGATION

During September 1994 through September 1995, Rockwell and the Lawrence Berkeley National Laboratory (LBNL) conducted a stable isotope investigation in the Area IV vicinity (LBNL, 1995). The purpose was to: 1) develop information to aid in assessing the dynamics of ground water movement, 2) form a basis for possible future active stable isotopic tracer tests to gather information that can facilitate a better understanding of local hydrogeologic parameters, and 3) obtain data of sufficient quality to adequately address hydrogeology-related issues associated with contaminated ground water restoration efforts in Area IV. In addition to sampling precipitation and surface water, ground water was sampled at most of the monitoring wells shown on Figure 4. Collectively, the analyses provided a means to 


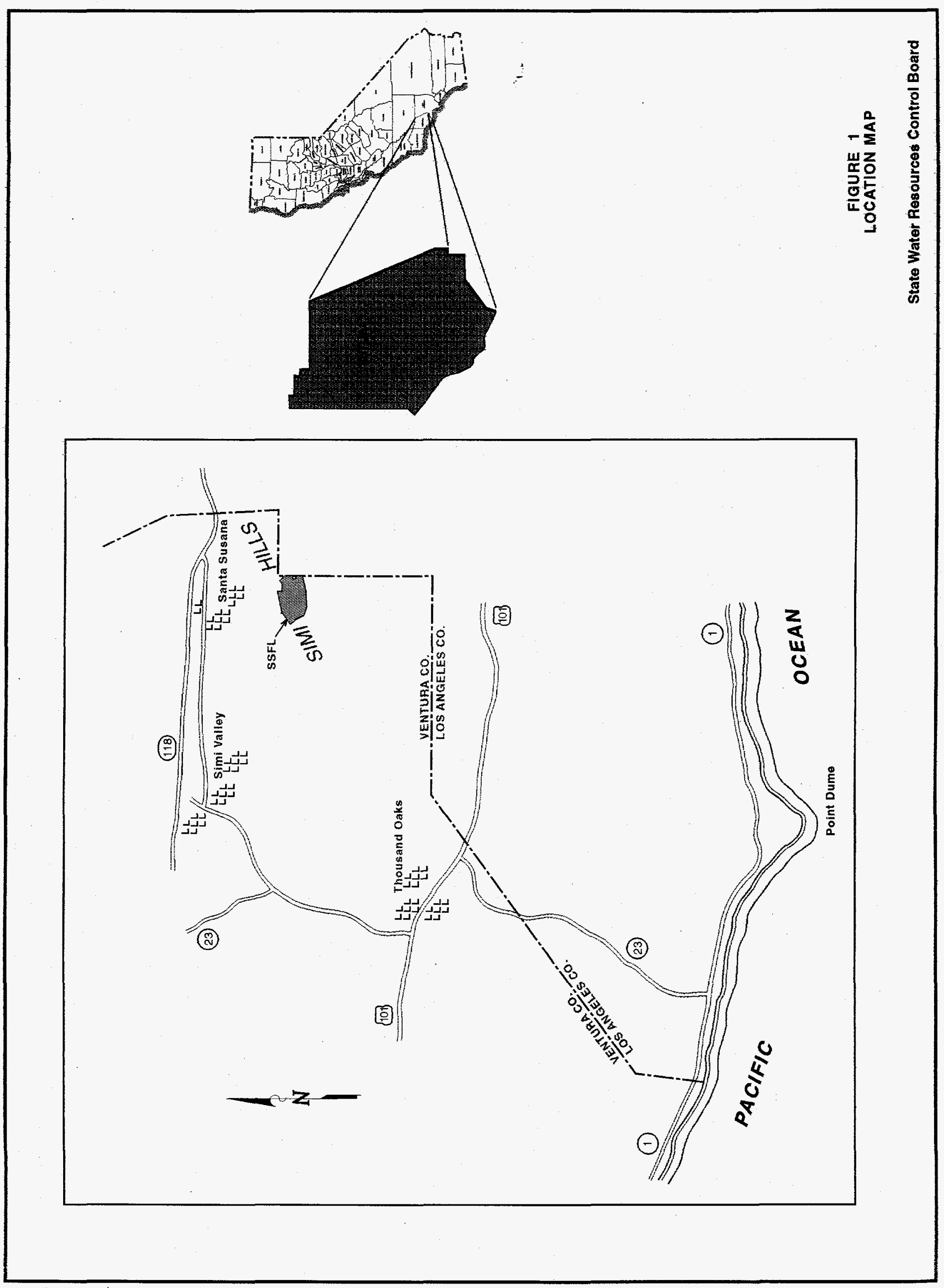




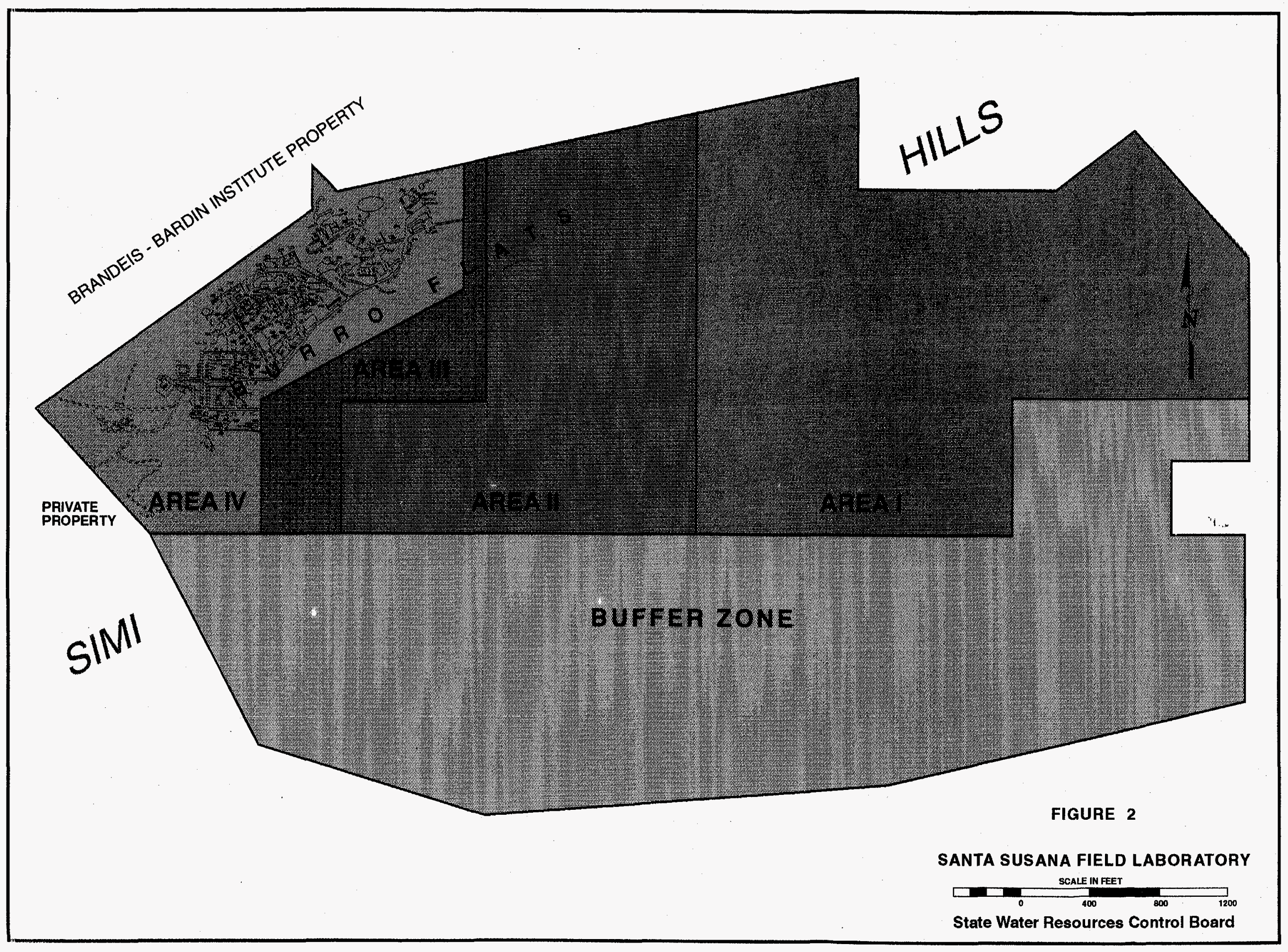


characterize the approximate time between the infiltration or recharge of water due to an isotopically distinguishable precipitation event and when that event's isotopic character could have been detected in ground water sampled at selected onsite/off-site Shallow Zone and Chatsworth Formation wells.

On the basis of four quarters of sampling, LBNL's main determinations on the stable isotopic character of Area IV ground water(s) can be summarized as follows:

1. Oxygen isotopic compositions in Shallow Zone ground water were slightly lower than those in that of the Chatsworth Formation during October/December 1994 first quarter sampling.

2. Ground water sampled (during the'first quarter) at most Chatsworth Formation wells exhibited an isotopic composition that reflected that of precipitation occurrence prior to October 1994.

3. The isotopic uniformity shown by the first-quarter Area IV ground water samples could be indicative of high hydraulic conductivities within the Shallow zone and Chatsworth Formation.

4. Excepting the results on the first quarter sample from OS-2, analyses indicated that ground water at the other off-site monitoring wells was isotopically indistinguishable from that sampled at most on-site wells.

5. The first, third, and fourth quarter OS-2 analyses indicated that ground water sampled at this off-site monitoring well is from an aquifer zone (Chatsworth Formation?) that is hydraulically separate from that in the Chatsworth Formation ground water beneath Area IV. 
6. Second, third, and fourth quarter analytical results showed subtle but persistent isotope composition position shifts that are indicative of rapid movement of infiltrating/percolating water from ground surface to the sampled shallow zone/Chatsworth Formation ground water.

In regard to the on-site and off-site spatial distribution of stable isotope compositions, LBNL indicated that the data demonstrated non-randomness on the following basis:

1. Ground water exhibiting certain narrow range oxygen isotope values was found along the "... southern portion of the site and in the off-site area to the southwest." and that "... two wells in the most northeastern portion of Area IV have similar isotopic composition.".

2. The distribution of another set of narrow-range oxygen isotope values to the northeast and southwest from Chatsworth Formation well RD-17 was consistent with the subsurface flow patterns that are inferable from the known ground water divide contours in that vicinity.

3. Oxygen isotope value distribution patterns suggest dominant subsurface flow directions to the northwest and southeast from the central part of Area IV.

Although quarterly sample analyses from most of the on-site and off-site wells indicated only slight isotope composition changes, relatively significant or anomalous shifts were observed in ground water at or near the: 1) Former Sodium Disposal Facility Area at Shallow Zone wells RS-18 and -23 and Chatsworth Formation wells RD-33B and $-54 \mathrm{C}, 2$ ) Building 59 Area at Shallow Zone well RS-27 and Chatsworth Formation well RD-24, and 3) RMDF Area at Shallow Zone well RS-25 and Chatsworth Formation well 
RD-19. In view of these compositional shifts, LBNL added that for these to occur over a sampling frequency of less than a year, it is necessary to have: 1) stable isotopic contrasts in ground water at individual wells and 2) high hydraulic conductivities (within the Shallow Zone and Chatsworth Formation) to allow introduction of significant quantities of isotopically distinct water within the relatively short one-year period of the investigation. Alternatively, LBNL suggested that the isotopic shifts possibly could be attributable to inadequate well construction and/or the direct introduction of surface water into the well.

Among various suggestions, LBNL recommended that: 1) quarterly sampling and analysis be continued to monitor isotope behavior changes for development of a basis for active stable isotopic tracer testing, 2) well-to-well tracer tests be designed to determine local directions and velocities of ground water flow and 3) the testing be initially performed at the cluster well locations.

LOCATION AND PURPOSE OF MONITORING WELLS IN THE AREA IV VICINITY

Wells that have been installed and/or used to characterize corresponding subsurface conditions at or near each of the aforementioned 10 DOE-identified sites are as follows:

1) Building 886, Former Sodium Disposal Facility -- Shallow Zone wells RS-18 and -54 ; Chatsworth Formation wells RD-22, -23 , $-33 \mathrm{~A},-33 \mathrm{~B},-33 \mathrm{C},-54 \mathrm{~A},-54 \mathrm{~B},-54 \mathrm{C},-57$, and -64 .

2) Building 59 Area, Former SNAP Reactor Facility -Chatsworth Formation wells RD-24, -25 , and -28 . 
3) RMDF (Leachfield) Area -- Shallow Zone well RS-28;

Chatsworth Formation wells RD-27, $-30,-34 A,-34 B,-34 C$, and -63 .

4) Old Conservation Yard --Former Shallow Zone well RS-26 was destroyed during soil excavation/underground storage tank removal in July 1989; Chatsworth Formation well at RD-14; Chatsworth Formation water supply well WS-7 (has not been sampled for laboratory analysis purposes since March 1992).

5) Building 56 Landfill Area -- Shallow Zone well RS-16; Chatsworth Formation well RD-7.

6) ESADA Chemical Storage Yard -- Shallow Zone well RS-23; Chatsworth Formation well RD-21.

7) Building 100 Trench Area -- Chatsworth Formation well $\mathrm{RD}-20$.

8) Southeast Drum Storage Area -- Shallow Zone well RS-24; Chatsworth Formation well RD-16.

9) New Conservation Yard - - Chatsworth Formation well RD-15.

10) Building 133, Hazardous Waste Management Facility -Shallow Zone well RS-25; Chatsworth Formation wells RD-18 (installed as a background well) and -19 .

Ground water monitoring installations within Area IV at locations other than near the foregoing 10 sites include Shallow Zone wells ES-31, RS-11, and -27 and Chatsworth Formation wells RD-13, -17 (upgradient from RMDF Area), -29 (upgradient from Building 59 Area), and -50 . 
Monitoring well cluster RD-33A, $-33 \mathrm{~B}$, and $-33 \mathrm{C}$ was installed to assess lateral and vertical hydrogeologic and possible contaminant occurrence variations within the Chatsworth Formation near the Former sodium Disposal Facility. Cluster RD-34A,-34B, and $-34 \mathrm{C}$ was installed for the same purpose within the Chatsworth Formation near the RMDF Area.

Chatsworth Formation well RD-50 was sited to characterize ground water conditions near the Burro Flats Fault.

Chatsworth Formation well cluster P.D-54A, $-54 \mathrm{~B}$, and $-54 \mathrm{C}$ was constructed within the Former Sodium Disposal Facility to evaluate the vertical extent of subsurface pollution and the associated hydrogeologic conditions.

Chatsworth Formation well cluster RD-59A, -54B, and -54C was installed to assess whether contaminated ground water occurs at that BBI property location.

Chatsworth Formation wells RD-63 and -64 were installed at their respective RMDF and Former Sodium Disposal Facility Area locations for the purpose of conducting pilot contaminated-ground water extraction tests.

Rockwell has indicated that all of the above wells are part of an ongoing SSFL-wide monitoring program that has been implemented to assess the nature and extent of subsurface pollution and to determine the effectiveness of an ongoing ground water remediation system. That system, which is installed and operated other than in Area IV, is for the purpose of extracting and hydraulically containing contaminant-impacted ground water (GWRC, 1995d) elsewhere within the SSFL. 
Important design factors that govern characterization results at drilled and constructed monitoring locations include details on: 1) well depth, 2) placement and depth interval of blank surface casing, 3) placement of screen and/or perforated-casing depth interval (s), 4) selection of open-hole depth interval, 5) placement of sand-pack depth interval, and 6) placement of cement/neat cement seal depth interval. Corresponding information available on the 51 wells that Rockwell has used to characterize/monitor Area IV ground water conditions is presented in the following table. 
Design Details of Area IV Monitoring Wells

(in feet)

\begin{tabular}{|c|c|c|c|c|c|c|}
\hline Well Number & Well Depth & $\begin{array}{c}\text { Blank Surface } \\
\text { Casing Depth } \\
\text { Interval }\end{array}$ & $\begin{array}{c}\text { Screened/Perfo- } \\
\text { rated Depth } \\
\text { Interval }\end{array}$ & $\begin{array}{c}\text { Open Hole } \\
\text { Depth Interval }\end{array}$ & $\begin{array}{c}\text { Sand/Gravel } \\
\text { Pack Depth } \\
\text { Interval }\end{array}$ & $\begin{array}{l}\text { Concrete/Neat } \\
\text { Cement Seal } \\
\text { Depth Interval }\end{array}$ \\
\hline ES-31 & 25.3 & $0-11.6$ & $11.6-25.3$ & (none) & $9.7-25.3$ & $0-9.7$ \\
\hline RS-11 & 17.5 & $0-9.0$ & $10.0-17.5$ & $“$ & $9.0-17.5$ & $0-9.0$ \\
\hline RS-16 & 20.5 & $0-16.5$ & $16.5-20.5$ & “ & $14.5-20.5$ & $0-14.5$ \\
\hline RS-18 & 13.0 & $0-7.5$ & $7.5-13.0$ & $“$ & $6.0-13.0$ & $0-6.0$ \\
\hline RS-23 & 13.0 & $0-8.0$ & $8.0-13.0$ & “ & $6.8-13.0$ & $0-2.5$ \\
\hline RS-24 & 8.5 & $0-4.0$ & $4.0-8.5$ & $“$ & $3.0-8.5$ & $0-1.5$ \\
\hline RS-25 & 13.5 & $0-8.5$ & $8.5-13.5$ & “ & $0-13.5$ & $\cdots$ \\
\hline RS-27 & 9.0 & $0-5.0$ & $5.0-9.0$ & $“$ & $3.3-9.0$ & $0-3.3$ \\
\hline RS-28 & 19.0 & $0-14.0$ & $14.0-19.0$ & “ & $9.0-19.0$ & $0-9.0$ \\
\hline RS-54 & 38.0 & $0-7.0$ & (none) & $7.0-38.0$ & (none) & $0-7.0$ \\
\hline $\mathrm{RD}-7$ & 300.0 & $0-25.0$ & $“$ & $25.0-300.0$ & $“$ & $0-25.0$ \\
\hline RD-13 & 160.0 & $0-30.0$ & $“$ & $30.0 \cdot 160.0$ & “ & $0-30.0(?)$ \\
\hline RD-14 & 125.0 & $0-30.0$ & “ & $30.0-125.0$ & “ & $0-30.0$ \\
\hline RD-15 & 152.0 & $0-30.0$ & $“$ & $30.0-152.0$ & $“$ & $0-30.0$ \\
\hline RD-16 & 220.0 & $0-30.0$ & 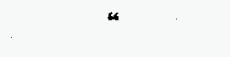 & $30.0-220.0$ & $"$ & $0-30.0$ \\
\hline RD-17 & 125.0 & $0-30.0$ & $“$ & $30.0-125.0$ & “ & $0-30.0$ \\
\hline RD-18 & 240.0 & $0-30.0$ & $“$ & $30.0-240.0$ & $“$ & $0-30.0$ \\
\hline RD-19 & 135.0 & $0-30.0$ & $“$ & $30.0-135.0$ & $“$ & $0-30.0$ \\
\hline RD-20 & 127.0 & $0-30.0$ & $“$ & $30.0-127.0$ & $“$ & $0-30.0$ \\
\hline $\mathrm{RD}-21$ & 175.0 & $0-30.0$ & “ & $30.0-175.0$ & $“$ & $0-30.0$ \\
\hline
\end{tabular}




\begin{tabular}{|c|c|c|c|c|c|c|}
\hline Well Number & Well Depth & $\begin{array}{l}\text { Blank Surface } \\
\text { Casing Depth } \\
\text { Interval }\end{array}$ & $\begin{array}{l}\text { Screened/Perfo- } \\
\text { rated Depth } \\
\text { Interval }\end{array}$ & $\begin{array}{c}\text { Open Hole } \\
\text { Depth Interval }\end{array}$ & $\begin{array}{l}\text { Sand/Gravel } \\
\text { Pack Depth } \\
\text { Interval }\end{array}$ & $\begin{array}{l}\text { Concrete/Neat } \\
\text { Cement Seal } \\
\text { Depth Interval }\end{array}$ \\
\hline $\mathrm{RD}-22$ & 440.0 & $0-30.0$ & $“$ & $30.0-440.0$ & $\star$ & $0-30.0$ \\
\hline RD-23 & 440.0 & $0-30.0$ & $“$ & $30.0-440.0$ & $"$ & $0-30.0$ \\
\hline RD-24 & 150.0 & $0-30.0$ & 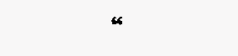 & $30.0-150.0$ & 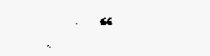 & $0-30.0$ \\
\hline RD-25 & 175.0 & $0-30.0$ & “ & $30.0-175.0$ & “ & $0-30.0$ \\
\hline RD-27 & 150.0 & $0-30.0$ & $“$ & $30.0-150.0$ & $\cdots$ & $0-30.0$ \\
\hline RD-28 & 150.0 & $0-30.0$ & $“$ & $30.0-150.0$ & “ & $0-30.0$ \\
\hline RD-29 & 100.0 & $0-30.0$ & $“$ & $30.0-100.0$ & “ & $0-30.0$ \\
\hline RD-30 & 75.0 & $0-30.0$ & “ & $30.0-75.0$ & “ & $0-30.0$ \\
\hline RD-33A & 320.0 & $0-100.0$ & $“$ & $100.0-320.0$ & “ & $0-100.0$ \\
\hline RD-33B & 678.0 & $0-360.0$ & $“$ & $360.0-415.0^{*}$ & “ & $0-360.0$ \\
\hline RD-33C & 520.0 & $0-480.0$ & $“$ & $480.0-520.0$ & “ & $0-480.0$ \\
\hline RD-34A & 60.0 & $0-16.0$ & (none) & $16.0-60.0$ & (none) & $0-16.0$ \\
\hline RD-34B & 240.0 & $0-180.0$ & “ & $180.0-240.0$ & 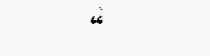 & $0-180.0$ \\
\hline RD-34C & 450.0 & $0-380.0$ & $“$ & $380.0-450.0$ & 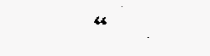 & $0-380.0$ \\
\hline RD-50 & 195.0 & $0-18.5$ & “ & $18.5-195.0$ & “ & $0-18.5$ \\
\hline RD-54A & 278.0 & $0-119.0$ & $*$ & $119.0-278.0$ & “ & $0-119.0$ \\
\hline RD-54B & 437.0 & $0-379.0$ & 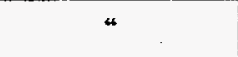 & $379.0-437.0$ & $“$ & $0-379.0$ \\
\hline RD-54C & 620.0 & $0-558.0$ & $“$ & $558.0-620.0$ & $"$ & $0-558.0$ \\
\hline RD-57 & 419.0 & $0-19.5$ & 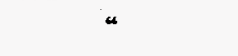 & $19.5-419.0$ & $"$ & $0-19.5$ \\
\hline RD-59A & 58.0 & $0-21.0$ & “ & $21.0-58.0$ & 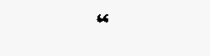 & $0-21.0$ \\
\hline RD-59B & 214.0 & (none) & $178.0-209.0$ & (none) & $161.0-214.0$ & $0-136.0^{* *}$ \\
\hline RD-59C & 398.0 & & $345.5-397.0$ & “ & $328.0-398.0$ & $0-310.0^{* * *}$ \\
\hline
\end{tabular}




\begin{tabular}{|c|c|c|c|c|c|c|}
\hline Well Number & Well Depth & $\begin{array}{l}\text { Blank Surface } \\
\text { Casing Depth } \\
\text { Interval }\end{array}$ & $\begin{array}{l}\text { Screened/Perfo- } \\
\text { rated Depth } \\
\text { Interval }\end{array}$ & $\begin{array}{l}\text { Open Hole } \\
\text { Depth Interval }\end{array}$ & $\begin{array}{c}\text { Sand/Gravel } \\
\text { Pack Depth } \\
\text { Interval }\end{array}$ & $\begin{array}{l}\text { Concrete/Neat } \\
\text { Cement Seal } \\
\text { Depth Interval }\end{array}$ \\
\hline RD-63 & 230.0 & $0-20.0$ & (none) & $20.0-230.0$ & (none) & $0-20.0$ \\
\hline RD-64 & 398.0 & $0-19.0$ & “ & $19.0-398.0$ & $“$ & $0-19.0$ \\
\hline RD-65 & 397.0 & $0-19.0$ & $“$ & $19.0-397.0$ & “ & $0-19.0$ \\
\hline WS-7 & 700.0 & (unknown) & $216.0-400.0$ & (unknown) & (unknown) & (unknown) \\
\hline OS-1 & (unknown) & $“$ & (unknown) & 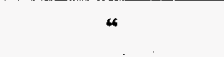 & “ & 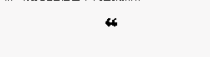 \\
\hline OS-2 & 700.0 & “ & (none) & “ & “ & $0-17.0$ \\
\hline OS-3 & (unknown) & $“$ & (unknown) & “ & $"$ & (unknown) \\
\hline OS-4 & $“$ & 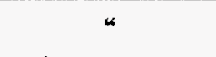 & “ & $“$ & “ & 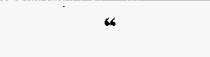 \\
\hline OS-5 & “ & . & “ & " & $\omega$ & “ \\
\hline
\end{tabular}

*. No information provided on whether RD-34B's 415.0- to 678.0-foot depth interval was sealed.

** A bentonite-sand mixture was installed at RD-59B's 136- to 161-foot depth interval.

*** Actually, bentonite and sand were installed at RD-59C's respective depth intervals of 182 to 186 and 186 to 250 feet. $<*>$

Depending on the location of the known or potential ground water pollution sources in relation to those of selected drilling sites in Area IV, the timing, placing, and sealing of surface casing must be optimal to ensure that the vertical (and possibly lateral) extent of contaminants is not exacerbated during that phase of monitoring well construction. In addition to maintaining surficial boring hole stability, this casing must be placed and sealed in a manner that will preclude the movement of (possible locally-occurring) contaminants from relatively shallow to deeper depths during subsequent drilling/construction/ monitoring activities. Furthermore, below the surface casing and its corresponding seal, the depth and length (or thickness) of well screen, perforated casing, open hole, and sand pack 
intervals must be designed in a manner that will negate exacerbating the vertical extent of possible locally-occurring contaminated ground water movement from a given depth to others at a completed monitoring well.

In regard to the designs of the four 3-well clusters at locations RD-33, -34, -54, and -59, Rockwell reported (GWRC, 1995b) that the "A" wells were typically completed to a depth of 40 - to 50-foot depth below the first ground water encountered while drilling within the Chatsworth Formation. Furthermore, the typical " $B$ " and " $C$ " completion depths were respectively selected at 200 to 250 and 350 to 450 feet below that first-encountered ground water.

\subsection{GROUND WATER QUALITY CONDITIONS}

The general ground water quality of Area IV depends primarily upon the: 1) mineral or chemical character of precipitation and/or local surface runoff that infiltrates the subsurface, 2) chemical character of the alluvium, Chatsworth Formation, and Martinez Formation through which water migrates, 3) chemical character of substances that have infiltrated the subsurface at the on-site identified potential or known sources, and 4) chemical character of substances that have infiltrated the subsurface at nearby SSFL localities.

IONIC CHARACTER OF GROUND WATER

Although precipitation and geologic-unit chemical character information has been collected as part of this investigation, there is a limited amount of standard minerals (cations/anions) 
content data on ground water samples that were collected immediately after some Area IV wells were installed. Where there has been no apparent extraneous-substance impact nor that which could be attributable to well construction, these ionic data indicate that naturally-occurring and/or background ground water (in the Shallow Zone and/or Chatsworth Formation) generally has a calcium bicarbonate character in the immediate vicinity of Area IV.

In the general downgradient direction from the Area IV ground water divide toward the BBI property, Rockwell has gathered ionic data along monitoring well alignments that respectively traverse the former Sodium Disposal Facility, former SNAP Reactor, and RMDF areas. These data suggest that as ground water moves northerly from the divide, its basic calcium bicarbonate character is slightly modified by mineral content increases possibly associated with previous Rockwell/ETEC activities. Only Chatsworth Formation ground water sampled at off-site wells RD-33C, $-34 \mathrm{C}$, and -57 did not exhibit those increases.

The analytical results on samples collected at off-site Chatsworth Formation cluster wells RD-59B and $-59 \mathrm{C}$ indicated an anomalous sodium bicarbonate character. Also, nearby RD-59A ground water was reported to reflect a sodium-calcium sulfatebicarbonate character.

Cation and anion concentrations in sampled ground water at offsite Chatsworth Formation wells RD-33A and $-33 B$ appear to have been significantly impacted by cement when each was sealed.

South-southeast from the Area IV ground water divide, available 
ionic information is too sparse to assess mineral concentration variations.

GROUND WATER POLLUTION

Ground water at Area IV monitoring wells has been selectively sampled to analyze for VoCs, base/neutral organic compounds, trace metals, cyanide, and radiological parameters (namely, gross alpha and beta activity, tritium, and man-made gamma emitting radionuclides).

Since TCE was initially detected at water supply well WS-7 in October 1986, known ground water pollution within and in the general downgradient direction from Area IV is predominated by its occurrence. TCE's presence in ground water within the Shallow Zone and the Chatsworth Formation has been reported as follows :

\section{Shallow Zone}

The most significant TCE concentrations in Shallow Zone ground water have been found in the vicinity of the Former sodium Disposal Facility. Ground water at monitoring wells RS-18 and -54 has exhibited these as high as 3,200 and 4,500 micrograms per liter (ug/l), respectively. Also, TCE content has varied from 46 to $86 \mathrm{ug} / 1$ at RS-28 in the RMDF area. Elsewhere, TCE in ground water generally has not been found at a $1.0 \mathrm{ug} / 1$ detection limit. Also, no analyses are available for RS-24. A summary of available data on individual well TCE concentration range in Shallow zone ground water is presented on the following table. 
TCE Concentrations in Shallow zone Ground Water

\begin{tabular}{|c|c|c|}
\hline Well Number & Number of Samples & TCE Content Range (in ug/l) \\
\hline ES-31 & 11 & Less than 1.0 Detection Limit \\
\hline RS-11 & 16 & \\
\hline RS-16 & 7 & “ \\
\hline RS-18 & 19 & Less than 1.0 Detection Limit \\
\hline RS-23 & 1 & - \\
\hline RS-24 & (none) & Less than 1.0 Detection Limit \\
\hline RS-25 & 1 & “ \\
\hline RS-27 & 3 & 46 to 86 \\
\hline RS-28 & 28 & 180 to 4,500 \\
\hline RS-54 & 9 & \\
\hline
\end{tabular}

\section{Chatsworth Formation}

As shown on Figure 7, TCE content of more than $5.0 \mathrm{ug} / 1$ in Chatsworth Formation ground water is prevalently found at monitoring wells in the respective vicinities of the Former Sodium Disposal Facility, Building 100 Trench Area/Building 56 Landfill Area, and RMDF Area. Moreover, as suggested on Figure 7, it may be found in excess of that concentration in the old Conservation Yard vicinity as part of an areal pollution pattern that extends from SSFI Areas II and III. Other than at RD-29 where TCE has varied from 0.7 to $4.0 \mathrm{ug} / 1$ in 21 ground water samples, this VOC generally has not been found at or in 


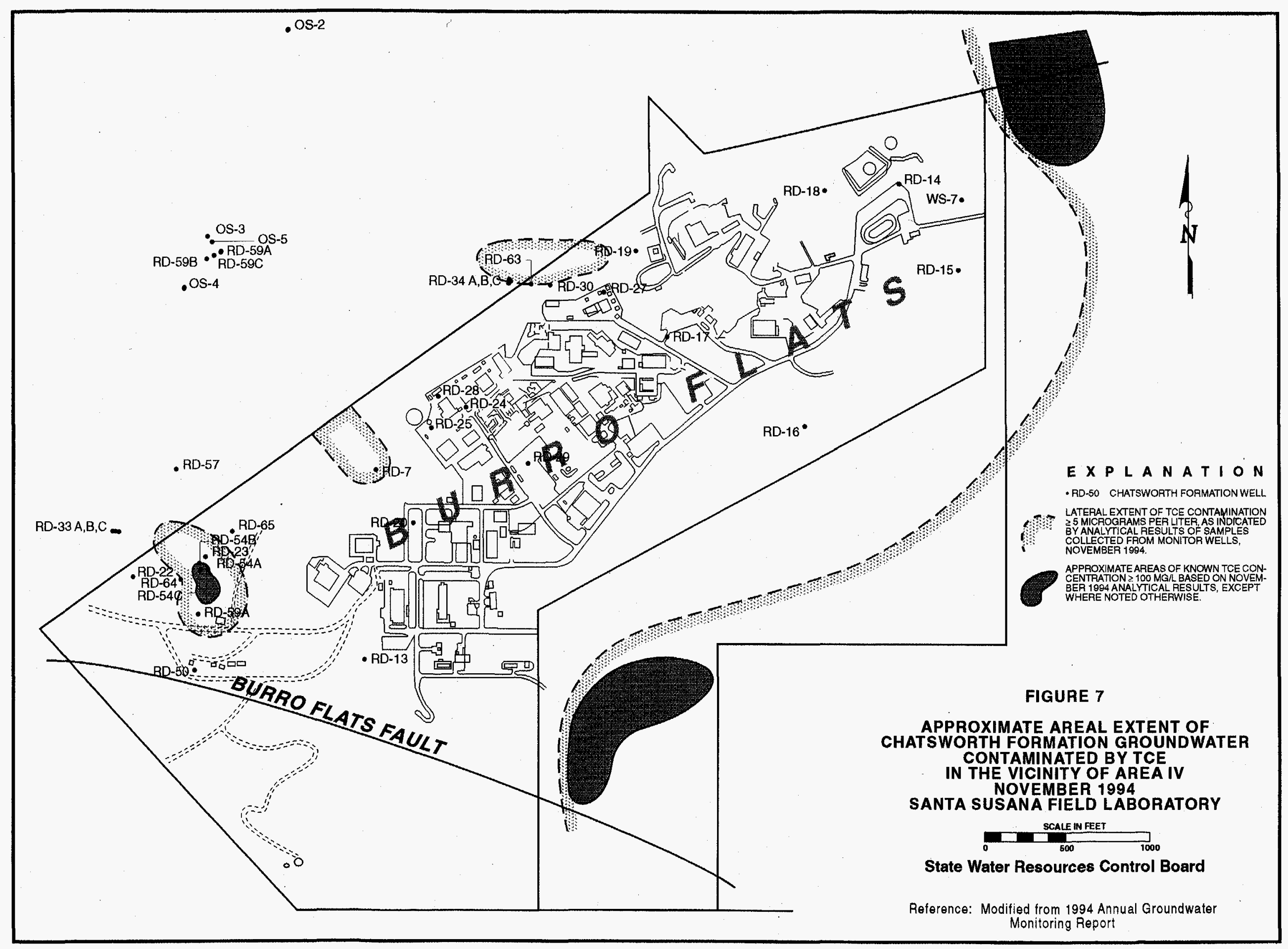


excess of a $1.0 \mathrm{ug} / 1$ detection limit in the remainder of Area IV.

When quarterly monitoring was conducted by Rockwell in

August 1995, AIP Program staff collected split samples for VoC analysis at Shallow Zone well RS-54 and Chatsworth Formation wells RD-54A, -54C, -57, -59A, -59B, -59C, and -63. Analytical results were found to be in general conformance with Rockwell's earlier reported VOC concentrations in ground water from those wells. The following table presents a summary of the TCE in concentration range in Chatsworth Formation ground water on a well-by-well basis and the corresponding number of samples/analyses on which each range is based.

TCE Concentrations in Chatsworth Formation Ground Water

\begin{tabular}{|c|c|c|}
\hline Well Number & Number of Samples & TCE Content Range (in ug/l) \\
\hline RD-7 & 37 & 12 to 130 \\
\hline RD-13 & 10 & Less than 1.0 Detection Limit \\
\hline RD-14 & 17 & Less than 0.2 to 13.0 \\
\hline RD-15 & 10 & Less than 0.2 to 0.53 \\
\hline RD-16 & 19 & Less than 0.2 to 3.0 \\
\hline RD-17 & 12 & 0.79 to 2.9 \\
\hline
\end{tabular}




\begin{tabular}{|c|c|c|}
\hline Well Number & Number of Samples & TCE Content Range (in ug/l) \\
\hline RD-18 & 19 & Less than 0.2 to 2.5 \\
\hline RD-19 & 17 & Less than 1.0 Detection Limit \\
\hline RD-20 & 12 & “ \\
\hline RD-21 & 30 & 89 to 2,900 \\
\hline RD-22 & 27 & Less than 1.0 Detection Limit \\
\hline RD-23 & 32 & 38 to 550 \\
\hline RD-24 & 13 & Less than 1.0 Detection Limit \\
\hline RD-25 & 16 & $“$ \\
\hline $\mathrm{RD}-27$ & 19 & $“$ \\
\hline RD-28 & 22 & $\cdot$ \\
\hline RD-29 & 21 & 0.7 to 4.0 \\
\hline RD-30 & 20 & 15 to 50 \\
\hline $\mathrm{RD}-33 \mathrm{~A}$ & 18 & Less than 1.0 to 9.5 \\
\hline RD-33B & 17 & Less than 1.0 Detection Limit \\
\hline RD-33C & 18 & “ \\
\hline RD-34A & 21 & Less than 0.4 to 82 \\
\hline RD-34B & 21 & Less than 0.5 to 11.0 \\
\hline RD-34C & 20 & Less than 1.0 Detection Limit \\
\hline RD-50 & 6 & Less than 0.5 to 6.1 \\
\hline RD-54A & 11 & 62 to 320 \\
\hline $\mathrm{RD}-54 \mathrm{~B}$ & 10 & Less than 1.0 to 1.7 \\
\hline RD-54C & 10 & Less than 1.0 to 1.0 \\
\hline RD-57 & 8 & Less than 1.0 Detection Limit \\
\hline
\end{tabular}




\begin{tabular}{|c|c|c|}
\hline Well Number & Number of Samples & TCE Content Range (in ug/l) \\
\hline RD-59A & 6 & \\
\hline RD-59B & 8 & " \\
\hline RD-59C & 6 & " \\
\hline RD-63 & 9 & Less than 1.0 to 8.9 \\
\hline RD-64 & 2 & Less than 1.0 to 420 \\
\hline RD-65 & 2 & 0.43 to 0.83 \\
\hline WS-7 & 23 & Less than 1.0 Detection Limit \\
\hline OS-1 & 43 & \\
\hline OS-2 & 40 & \\
\hline OS-3 & 22 & " " \\
\hline OS-4 & 22 & " \\
\hline OS-5 & 41 & \\
\hline & & \\
\hline & & \\
\hline
\end{tabular}

Gross alpha or beta radioactivity in some ground water samples has exceeded the respective maximum contaminant levels (MCLs) of 15 and 50 picocuries per liter (pCi/1) at: 1) Shallow zone wells RS-18, -28 , and -54 and ES-31, and 2) Chatsworth Formation wells $\mathrm{RD}-18,-27$, and -28 .

Tritium's 20,000 pCi/1 MCL has not been exceeded in sampled ground water for such analysis. There has been no confirmation of the presence of man-made gamma emitting radionuclides in ground water from Chatsworth Formation wells RD-33B, $-34 \mathrm{~A}$, and $-34 \mathrm{~B}$.

\subsection{ADEQUACY OF EXISTING GROUND WATER MONITORING SYSTEM}

Understanding that the objective of the AIP Program is to assess the monitoring system adequacy for detecting the leakage of 
substances that can potentially degrade or have degraded ground water quality, comments on Rockwell's characterization of Area IV hydrogeologic and associated ground water pollution conditions are as follows:

1. Even though only meager information that has been provided on the occurrence and movement of Shallow Zone ground water, the TCE concentrations reported at RS-18, -28 , and -54 suggest that the over-all subsurface configuration of such pollution has not been delineated properly in the respective vicinities of the Former Sodium Disposal Facility and the RMDF Area. Furthermore, Rockwell has not presented any evidence which illustrates that pollutants have not or cannot move laterally within the Shallow zone in directions other than those of the underlying Chatsworth Formation ground water.

2. There is no available delineation or illustration of the areal and vertical configuration of the weathered Chatsworth Formation portion of the Shallow zone. In the absence of this information, the ability of the weathered Chatsworth Formation to store and/or transmit ground water laterally beyond the alluvial Shallow zone area of Burro flats remains inadequately understood.

3. Shallow Zone Well RS-23's limited 13-foot depth has disallowed quarterly ground water monitoring at that location.

4. The lateral and vertical extent of TCE concentrations in Shallow zone ground water at RS-54 is unknown in the direction of the TCE-contaminated Chatsworth Formation ground water at well RD-21. It is noteworthy that RD-21's surface casing/seal is only 30 feet deep but the depth of the weathered Chatsworth Formation portion of the Shallow zone is unknown. 
5. TCE concentrations in Chatsworth Formation ground water suggest that the bulk of the pollution beneath the Former sodium Disposal Facility was above the open hole depth interval of RD-54B, possibly above the 278-foot depth of RD-54A, and most likely above RD-21's 175-foot depth. In light of the location and design details of these wells, it appears that the vertical extent of TCE pollution was extended to deeper depths (by virtue of well installation) beyond that which existed before the drilling and well construction activities at that locality.

6. In relation to the Former Sodium Disposal Facility, the hydraulically upgradient lateral extent of TCE concentrations in Chatsworth Formation ground water has not been defined beyond the monitoring well RD-21.

7. TCE concentrations in Chatsworth Formation ground water at cluster wells RD-33A, $-33 \mathrm{~B}$, and $-33 \mathrm{C}$ suggests that the lateral extent of pollution, in the general hydraulically downgradient direction from the Former sodium Disposal Facility, has occurred above a depth of 320 feet. That lateral pollution extent beyond and/or in the vicinity of this cluster remains unknown.

8. The water levels at $R D-33 B$ and $-33 C$ are virtually the same. Either the respective open hole depth intervals are hydraulically connected naturally or the RD-33C seal is ineffective.

9. TCE concentrations in ground water at well R.D-57 suggest that this Chatsworth Formation well is not hydraulically downgradient from the pollution beneath the Former sodium Disposal Facility. 
10. Based on one sample obtained in February 1995, a. $420 \mathrm{ug} / 1$ TCE content in ground water at Chatsworth Formation well RD-65 suggests that the November 1994 areal extent of pollution in the Former Sodium Disposal Facility vicinity needs to be expanded accordingly.

11. The prevailing lateral and vertical extent of TCE concentrations in ground water at Chatsworth Formation well RD-7 (located in the Building 56 Landfill Area) has remained undetermined since 1986.

12. In the general hydraulically downgradient direction from the RMDF Area, TCE concentrations in Chatsworth Formation ground water at cluster wells RD-34A, $-34 \mathrm{~B}$, and $-34 \mathrm{C}$ suggest that the vertical extent of pollution at that locality is to a depth above 380 feet. These data also suggest that most of the pollution is above a 180-foot depth but its lateral extent remains undetermined within the BBI property.

13. Generally, Rockwell has defined the extent of TCE occurrence in Chatsworth Formation ground water on the basis of its non-detection at concentrations of $1.0 \mathrm{ug} / 1$ or less. However, it should be anticipated that TCE content in certain Chatsworth Formation ground water samples have been subject to dilution (attributable to the open hole/screened length designs) and to volatilization (due to the selected sampling method as observed by SWRCB AIP staff during August 1995).

14. The similarity in the RD-34A and $-34 B$ Chatsworth Formation ground water level fluctuation trends suggests that these wells may be hydraulically interconnected. 
15. The dissimilarity of the $\mathrm{RD}-34 \mathrm{~A}$ and $-34 \mathrm{~B}$ water level fluctuations from those of RD-34C's confined/pressure condition suggests that there is more than one Chatsworth Formation ground water system.

16. TCE concentrations in Chatworth Formation ground water at $R D-30$ and $-34 \mathrm{~A}$ suggest that most of the pollution beneath the RMDF Area may be above a 100-foot depth.

17. Although a content range of only 0.7 to $4.0 \mathrm{ug} / 1 \mathrm{TCE}$ was detected in 21 Chatsworth Formation ground water samples from RD-29, the source and extent of this pollution remains unknown.

18. TCE occurrence in Chatsworth Formation ground water at supply well WS-7 and RD-14, -15 , and -18 (located in the vicinities of the Old and. New Conservation Yards) does not appear to be attributable to ETEC activities.

19. The limited ionic data obtained at the RD-59 cluster suggests that the chemical character of Chatsworth Formation ground water at the three wells is dissimilar from that beneath and adjacent to Area IV.

20. Available test data obtained at extraction wells RD-63 and -64 suggest that Chatsworth Formation hydraulic conductivities are low in the Area IV vicinity.

21. The unconfined and confined/artesian water conditions encountered at well clusters $R D-33,-34,-54$, and -59 have not been studied elsewhere at other Chatsworth Formation monitoring installations. Lack of such data suggests that the vertical and lateral flow (of contaminated ground water at possibly various depth intervals within this formation) is minimally understood. 
Additionally, in view of the designed open hole depth intervals, the confined and unconfined water levels suggest that chatsworth Formation wells can serve as artificial conduits for the vertical (and possibly consequent lateral) movement of contaminated ground water.

22. Depending on the spatial extent of pollution prior to drilling in the vicinities of some identified sources, the selected blank surface casing and seal depth interval designs were inadequate to ensure against artificially exacerbating the then existing subsurface pollution configuration (before monitoring well installation was completed). Also, it is questionable that most installed surface casing seals can effectively preclude near-surface pollutant and/or rapid surficial water entry (either along the well annulus or otherwise) especially into the non-clustered Chatsworth Formation wells.

\subsection{CORRECTIVE ACTION}

Since 1987, Rockwell has operated a ground water reclamation system that includes pumpage at extraction wells located within the SSFL facility other than in Area IV. The purpose of that system is to hydraulically prevent the movement of contaminated Chatsworth Formation ground water from the facility to off-site areas.

The only Area IV well that may be subject to influence by the reclamation system ground water withdrawals could be water supply well WS-7. Water levels at this well declined about 36 feet from 1987 through 1994 (GWRC, 1995a). Nonetheless, it is evident that the previously-described Area IV contaminated ground water (in the WS-7 vicinity and elsewhere) has migrated off-site and has 
not been hydraulically controlled by the reclamation systemlowered Chatsworth Formation water levels.

\subsection{CONCLUSIONS AND RECOMMENDATIONS}

The following conclusions and recommendations are intended to provide a basis for modifying or improving the current Area IV ground water monitoring system. Based on the data reviewed, these primarily reflect the comments on the adequacy of the existing system and/or that the characterization of the extent of Area IV ground water pollution is incomplete.

CONCLUSIONS

1. The existing Shallow Zone and Chatsworth Formation monitoring well network does not enable the collection of meaningful hydrogeologic and ground water quality data that can be utilized as reliable design criteria to construct and operate a system that can effectively remediate subsurface pollution attributable to ETEC activities.

2. In view of the existing network design, there is no need to sample ground water at most monitoring wells as frequently as the available data indicate. TCE (and related pollutants) concentrations in ground water essentially have remained the same as initially found. Generally, other than determining the presence or absence of pollutant $s$ at individual wells, the available data suggest that long-term gathering of essentially the same information at individual wells has been of limited technical value.

3. In spite of the inappropriateness of certain deep well designs, on the basis of the: 1) confined/ unconfined Chatsworth 
Formation conditions, 2) prevailing chatsworth Formation ground water divide, and 3) the relative lack of Chatsworth Formation water level decline due to SSFL pumpage, it is apparent that more than one Chatsworth Formation ground water system exists in the Area IV vicinity and that the local geologic/hydrogeologic framework needs to be better understood and/or Rockwell's conceptualized hydrogeologic model needs modification.

4. The areal geology presented on the Figure 4 map suggests that there is a lack of surficial information on Chatsworth Formation fractures/rock openings and associated geologic data within the BBI and adjoining private property which otherwise could be useful in planning possible subsurface characterization work in the future.

5. Characterization of subsurface pollution in the Area IV vicinity and corresponding remedial action efforts since 1985 have been too limited and insufficiently discerning.

RECOMMENDATIONS

1. Prior to establishing any need for installing new wells in the Area IV vicinity, the hydrogeologic integrity of existing shallow and deep wells should be evaluated and possibly individually modified as feasible. The purpose would be to optimize the use the present well network with the intent to develop a meaningful monitoring program that can provide discrete and/or definitive criteria for the design and implementation of an effective remediation system for Area IV. Such work would include removal of dedicated submersible pumps and appurtenances at selected wells to allow implementation of appropriate evaluative techniques. 
2. In conformance with LBNL's recommendation, studies to determine local ground water flow directions/velocities should be performed pursuant and/or in conjunction with the above work to optimize the well selection and design of the tracer tests.

3. Subsequent to hydrogeologic-integrity evaluation and possible modification of existing well designs, a comprehensive background ground water quality assessment should be conducted to facilitate an improved understanding of Shallow zone and Chatsworth Formation hydrogeologic parameters that are pertinent to Area IV. 


\subsection{REFERENCES}

Ground Water Resources Consultants, Inc., "Annual Ground water Monitoring Report, Santa Susana Field Laboratory, 1989, Rockwell International Corporation, Rocketdyne Division, Ventura County, California". October 9, 1990.

"Site Characterization Plan, Santa Susana Field Laboratory, Rockwell International Corporation, Rocketdyne Division, Ventura County, California". June 4, 1991.

, 1992a, "Annual Ground water Monitoring Report, Santa Susana Field Laboratory, 1991, Rockwell International Corporation, Rocketdyne Division, Ventura County, California". February 26, 1992 .

, 1992b, "Well Compendium, Rockwell International Corporation, Rocketdyne Division, Santa Susana Field Laboratory, Ventura County, California". April 10, 1992.

, 1992c, "Completion Report, Cluster Well Sites RD-33, RD-34, and RD-51, Santa Susana Field Laboratory, Rockwell International Corporation, Rocketdyne Division, Ventura County, California". April 24, 1992.

Cores, Santa Susana Field Laboratory, Rockwell International Corporation, Rocketdyne Division, Canoga Park, California". May 4, 1992 .

"Hydrogeologic Conditions, B/886 Former Sodium Disposal Facility Area, Santa Susana Field Laboratory, Rockwell International Corporation, Rocketdyne Division, Ventura County, California". April 15, 1994.

Susana Fiel'd Laboratory, 1994, Rockwell International Corporation, Rocketdyne Division, Ventura County, California". February 24, 1995.

1995b, "Summary of Ground water Conditions at and in the Regional Vicinity of the B/886 Former Sodium Disposal Facility Area, Santa Susana Field Laboratory, Rockwell International Corporation, Rocketdyne Division, Ventura County, California". May 16, 1995.

1995c, "Results of Well RD-63 Pilot Extraction Test, RMDF Area, Santa Susana Field Laboratory, Rockwell International 
Corporation, Rocketdyne Division, Ventura County, California". May 22, 1995.

, 1995d, "Ground water Monitoring Quarterly Report, Santa Susana Field Laboratory, First Quarter, January Through March 1995, Rockwell International Corporation, Rocketdyne Division, Ventura County, California". May 26, 1995.

1995e, "Technical Data Summary, Construction, Testing, and Sampling of Monitoring wells Completed During 1993 and 1994, Santa Susana Field Laboratory, Rockwell International Corporation, Rocketdyne Division, Ventura County, California". June $15,1995$.

Mukherjee, N., "Site Ground water Characterization Plan, Area IV, Santa Susana Field Laboratory, Rockwell International

Corporation, Rocketdyne Division, Ventura County California". March 1994. Rocketdyne Division Report.

Smith, B.M., Menchaca, L.B., "Energy Technology Engineering Center, Stable Isotope Investigation, Report on FY95 Scope of Work". December 1995. Lawrence Berkeley National Laboratory Report.

Rocketdyne, 1992, "Ground water Management Plan for ETEC, Santa Susana Field Laboratory, Area IV, Rockwell International Corporation, Rocketdyne Division. September 1992. Rocketdyne Division Report. 


\title{
State Water Resources Control Board 1995 AIP Summary Report
}

\section{LABORATORY FOR ENERGY-RELATED HEALTH RESEARCH}

\author{
Prepared For:
}

\begin{abstract}
UNITED STATES DEPARTMENT OF ENERGY OAKLAND OPERATIONS
\end{abstract}

Prepared By:

DENNIS PARFITT

ASSOCIATE ENGINEERING GEOLOGIST STATE WATER RESOURCES CONTROL BOARD

DIVISION OF CLEAN WATER PROGRAMS SACRAMENTO, CALIFORNIA

MARCH 1996 


\subsection{INTRODUCTION}

This report presents findings, conclusions, and recommendations developed by SWRCB staff regarding the Iaboratory for EnergyRelated Health Research (LEHR) facility in conformance with the DOE's AIP program. Ground water quality and other data presented in this report were collected in 1995 by AIP staff to facilitate evaluation of the adequacy of the facility's monitoring system to detect releases that could impact public health and safety and the environment. This report does not incorporate most data recently developed by UC Davis/DOE (post fall 1995) which may have a bearing on the findings and conclusions presented herein. The report does present a quantitative evaluation of the adequacy of the ground water monitoring system at the LEHR facility and tabular and graphical presentations of hydrogeologic data obtained by AIP staff in 1995. The data include ground water elevation measurements from selected monitoring wells and analyses of ground water samples from on-site monitoring wells and off-site supply wells for stable isotopes of hydrogen, oxygen, and nitrogen, general minerals, chlorinated volatile organic compounds, and/or radionuclides. A thorough evaluation of the surface water monitoring system is not included as SWRCB staff focused on the ground water system. Results of limited surface water sampling are included, however.

The LEHR facility is located about one mile south of the main UC Davis campus (Figure 1) and encompasses approximately 15 acres. Researchers at the facility conducted radiological studies on laboratory animals for DOE from the late 1950's until 1989. Beginning in the 1940's through 1967, UC Davis operated three separate landfills at or near the site. The following sections of this report provide: 1) background information on the LEHR site including a discussion of SWRCB staff's inspection of the site's hydrogeologic setting, the nature and extent of pollution, 


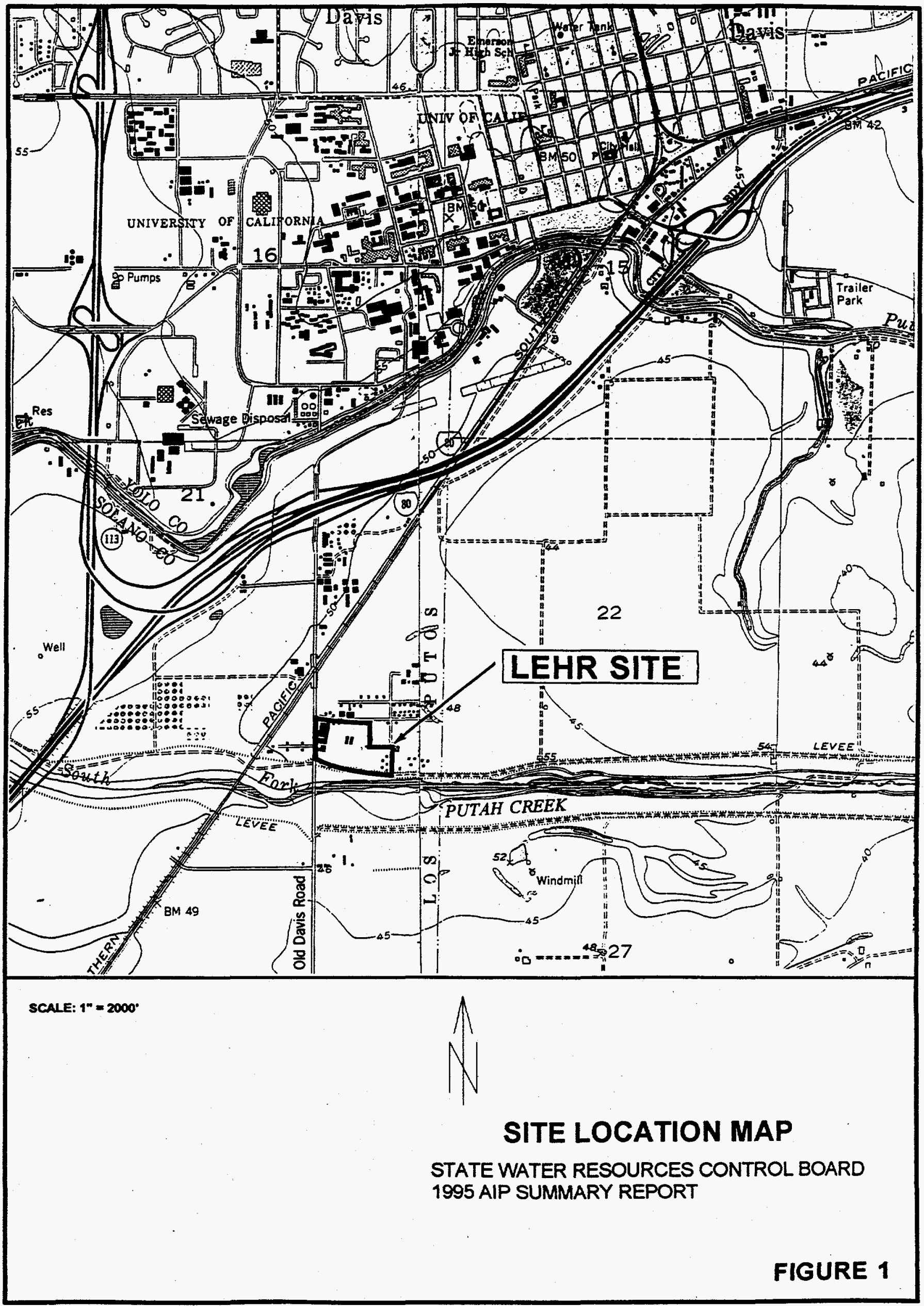


and degree to which environmental impacts have been characterized and/or mitigated, 2) the hydrogeologic conceptual model developed by SWRCB staff and the water quality, ground water elevation, and stable isotope data collected during 1995 by AIP staff in the context of the model, 3) the adequacy of the ground water monitoring system at the site and the results of AIP sample analyses used to evaluate analytical procedures at the DOE contract laboratory, and 4) the findings developed through the State's participation in the AIP program and recommendations for improving the present ground water monitoring system.

\subsection{BACKGROUND}

Low-level radioactive solid waste, non-radioactive liquid waste, laboratory chemicals and solid waste, and/or trash was discarded on-site in 49 pits, 19 trenches, three landfill disposal units, three dry wells, and six septic tanks as a consequence of DOE sponsored research and non-DOE university activities (Dames \& Moore, 1993). The locations of the known waste disposal areas are shown on Figure 2. Not represented on Figure 2 is a third landfill disposal unit located about 600 feet east of landfill disposal unit 2. The three landfill units were operational, in a staged sequence, from the 1940s until 1967.

The initial investigation of possible environmental impacts at the LEHR site (Phase I Site Characterization) commenced in 1987 with the installation of nine ground water monitoring wells, the collection of soil samples from backhoe trenches and soil borings, and the analyses of soil and ground water samples for radionuclides, metals, and chemical constituents. In 1989, five additional ground water monitoring wells were installed and soil, surface, and ground water samples analyzed to assess potential environmental impacts associated with the three inactive landfill units. In 1990, Phase II Site Characterization commenced with 


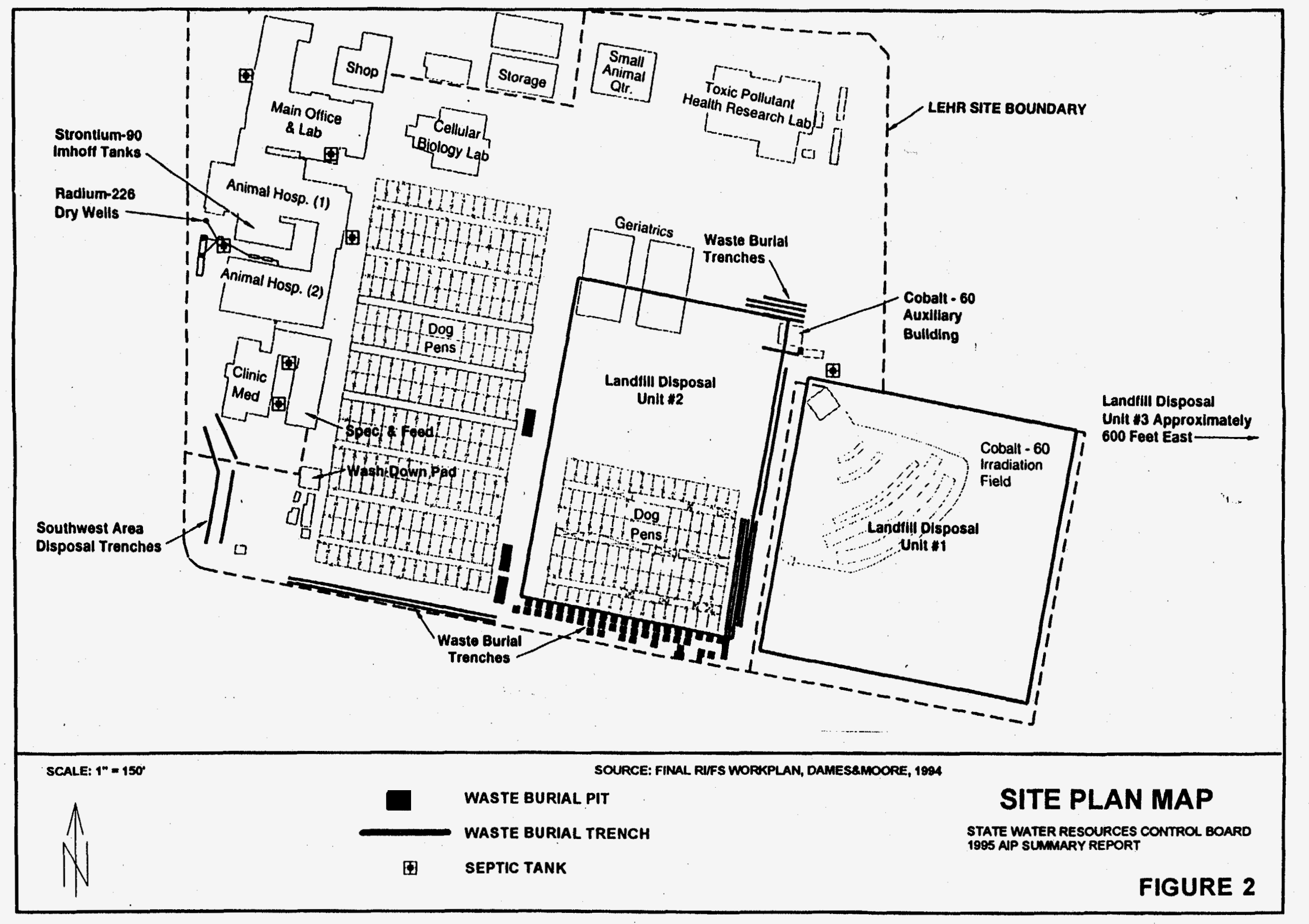


the installation of additional monitoring wells, and continued characterization of soil and ground water pollution. Concurrent with the site characterization work, surplus chemicals and identifiable biologic and low-level radiologic wastes were contained and transported off-site for disposal.

During 1995, the focus of site investigative activities included continued characterization of soil pollution and pollution sources and defining more completely the nature and extent of ground water pollution. Additional monitoring wells were installed, the application of hydropunch technology was used, and the quantification of aquifer properties was undertaken. State AIP staff aided in the investigative efforts by installing continuous water level recorders on selected site wells, obtaining stable isotope analyses of water samples from site monitoring wells, and collecting ground water samples from offsite water supply wells for chemical analyses.

CONSTITUENTS OF CONCERN

As a consequence of the nature of DOE-sponsored research carried out at the LEHR facility and the normal operations at the University, radiologic, biologic and chemical and solid wastes were discarded in the various pits, trenches, septic systems, dry wells, and landfill units at the site. During the various phases of site characterization, the constituents of concern (COC) presented in Table 1 , have been identified to be present in soil and ground water as a consequence of past waste management practices and chemical usage: 
TABLE 1

CONSTITUENT OF CONCERN

UCD/DOE LEHR FACILITY

Organics

Phthalates

Organochlorine Pesticides

Chlorinated Organic Compounds Carbon-14

(solvents and associated Radium-226

degradation products)
Radionuclides

Tritium $\left({ }^{3} \mathrm{H}\right)$

Strontium-90
Inorganics

Nitrate

Chromium

NATURE AND EXTENT OF PROBLEM

Chlorinated volatile organic compounds (VOCs), nitrate, chromium, carbon-14, and tritium are the COCs which have significantly impacted ground water beneath the LEHR facility. Of these constituents, the VOCs and possibly nitrate and chromium have migrated off-site to the east and northeast. Ground water sampling of off-site supply wells by AIP staff have shown that VOC affected ground water is present up to 1500 feet east of the UCD eastern property Iine.

\subsection{HYDROGEOLOGIC CONCEPTUAL MODEL}

To evaluate the adequacy of a ground water monitoring system, one must understand as completely as possible the sources of pollutants, the physical conditions at a site that influence pollutant transport, the nature of the pollutant, and receptor exposure. This understanding is derived by a detailed study of available data and the development of a realistic site hydrogeologic conceptual model. The following discussion presents an overview of the hydrogeologic conceptual model developed by SWRCB AIP staff after reviewing available information. Supporting data collected by AIP staff are 
presented following the conceptual model discussion.

HYDROSTRATIGRAPHIC UNITS

The geologic units of interest at and in the vicinity of the LEHR facility can be divided into two primary geostratigraphic units; alluvial-fan deposits of Pleistocene and Holocene age and the Pliocene Tehama Formation (Olmsted and Davis, 1961). The alluvial-fan deposits are fluviatile sediments that have been deposited in the Sacramento Valley as a consequence of weathering and erosion of geologic units of the coast Range and uplands west of winters. The alluvial-fan deposits in the vicinity of the LEHR facility are about 125 feet thick and consist of beds and lenses of clayey silt, silt, sandy silt, and sand and gravel. The Tehama Formation consists of fluviatile sediments derived from erosion of the coast Range, is in excess of 1000 feet thick in the vicinity of LEHR and consists of massive beds of silty clay and clayey silt interspersed with relatively thin beds and lenses of sand and gravel.

Relative to the LEHR site, four rather distinct hydrostratigraphic units (HSU) are identifiable. The upper two are subdivisions of the alluvial-fan deposits of Pleistocene and Holocene age. These units, from ground surface downward, are: 1) predominantly fine-grained alluvial-fan sediments (A.K.A. first hydrostratigraphic unit - HSU1), and 2) relatively coursegrained alluvial-fan sediments (A.K.A. second hydrostratigraphic unit - HSU2) which comprises the first regional aquifer. The lower two HSUs are subdivisions of the Pliocene Tehama Formation. The units, from the base of the second HSU downward are:

1) predominantly fine-grained alluvial sediments (hereafter referred to as the third hydrostratigraphic unit - HSU3), and 2) relatively course-grained alluvial sediments (hereafter referred to as the forth hydrostratigraphic unit - HSU4) which 
comprises the second regional aquifer. Each of the four HSUs and their interrelationships are describe in more detail below. Figures 3 and 4 present a schematic of the four HSUs and the inferred movement of ground water during the summer and winter, respectively.

\section{Eirst Hydrostragtigraphic Unit}

The first HSU extends from ground surface to a depth of about 80 feet and consists primarily of clayey silt, sandy silt, and silty fine sand with thin beds or lenses of sand and/or gravel. This HSU is further divided into two subunits, the vadose zone which extends to a depth of about 30 feet, and the saturated zone which extends from the base of the vadose zone to the top of the second HSU. The first HSU is characteristic of an aquitard and represents a significant reservoir of ground water for area water supply wells.

Horizontal hydraulic conductivity of the saturated portion of the first $H S U$ is estimated to range from $1.4 \times 10^{-4} \mathrm{~cm} / \mathrm{sec}$ to $5.2 \times 10^{-3} \mathrm{~cm} / \mathrm{sec}$ (PNL 1995); vertical hydraulic conductivity is estimated by AIP staff to range from $5.5 \times 10^{-5} \mathrm{~cm} / \mathrm{sec}$ to $1.2 \times 10^{-4} \mathrm{~cm} / \mathrm{sec}$ (Appendix A). The horizontal hydraulic gradient (slope of the water table) varies across the site, ranging from a high of about 0.003 near the southern part of the facility to a low of about 0.001 in the northern and eastern parts of the facility. The vertical hydraulic gradient varies in direction and magnitude temporally. During the agricultural irrigation season, usually March through August, the gradient is downward and usually fluctuates between 0.05 and 0.12 on a daily basis. During the remainder of the year, the gradient tends to vary from near zero to 0.05 upward. 


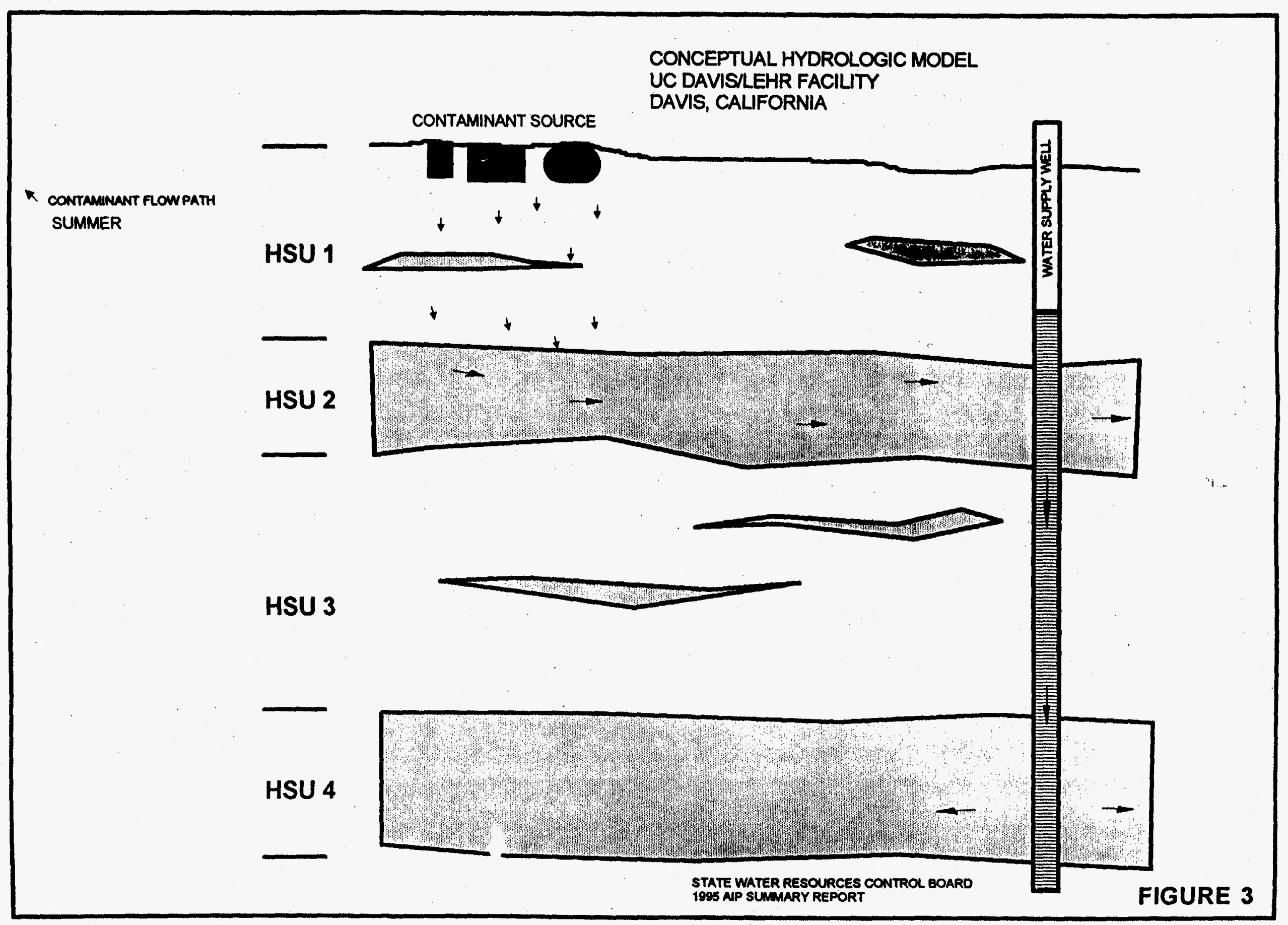




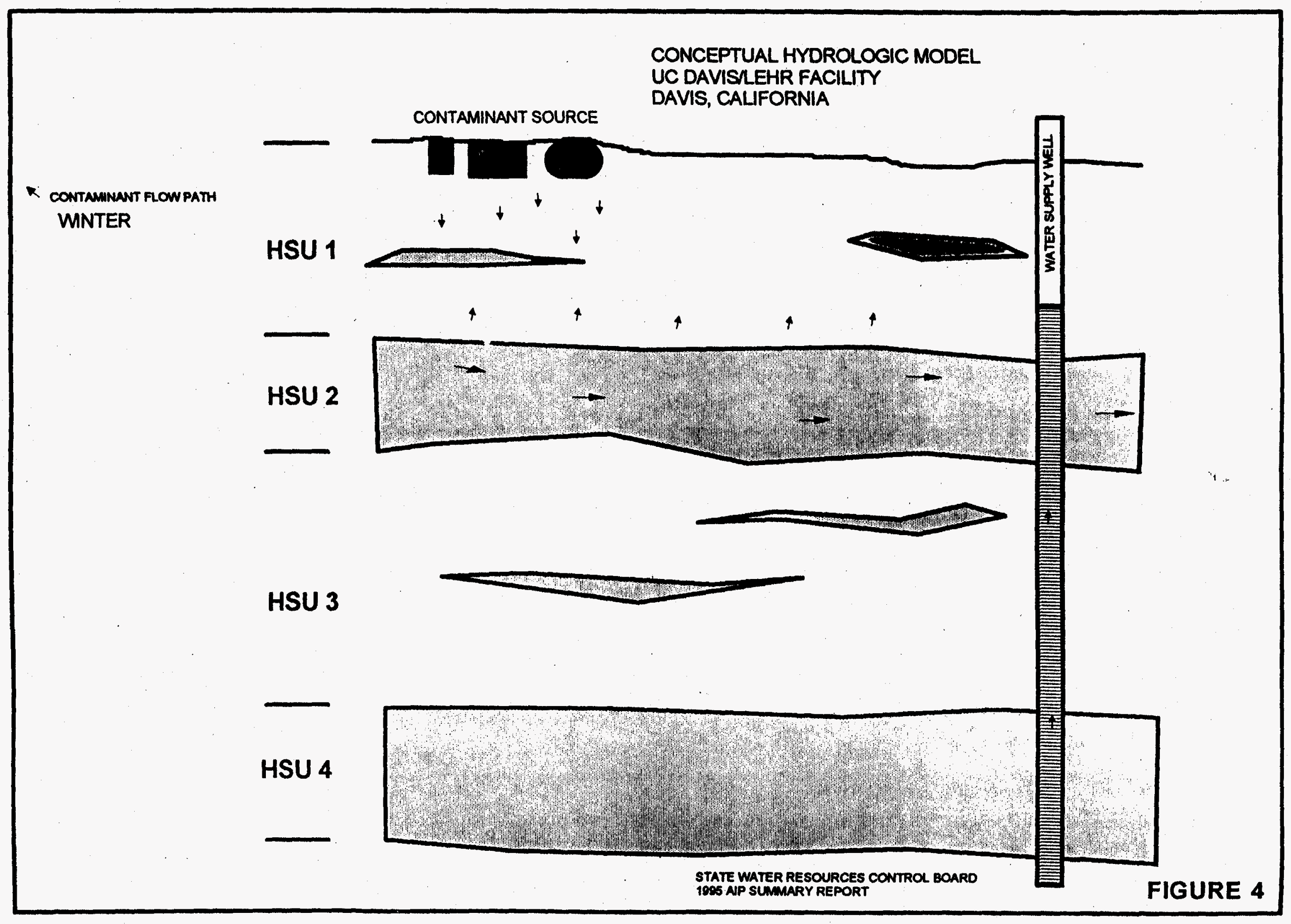


Second Hydrostratigraphic Unit

The second HSU is present at the LEHR facility in the depth interval of about 80 to 125 feet. It is comprised of sand, gravel, and cobble sized sediments, is laterally continuous on a regional scale and represents the first major aquifer underlying the Davis area. Horizontal hydraulic conductivity of the second HSU is estimated to range from $4.9 \times 10^{-2} \mathrm{~cm} / \mathrm{sec}$ to $2.3 \times 10^{-1} \mathrm{~cm} / \mathrm{sec}(\mathrm{PNL}, 1995)$. The horizontal hydraulic gradient observed at the site ranges from a low of about 0.0009 to a high of about 0.0018 . The higher hydraulic gradient is associated with the agricultural irrigation season while the lower gradient corresponds to the remainder of the year when consumptive use of ground water is minimal.

\section{Third Hydrostratigraphic Unit}

The third HSU, based on Well Driller's Reports of water supply wells near the LEHR facility, extends from the base of the second HSU to a depth of about 250 feet below grade. It is comprised of clayey silt and silty clay with interspersed thin beds and lenses of sand and gravel. It is laterally continuous on a regional scale. While lithologically similar to the first HSU, the third HSU sediments are more compact (denser) owing to their older geologic age and greater depth of burial. Specific information on the hydraulic conductivity (horizontal and vertical) of the third HSU is lacking, though based on its physical characteristics, its conductivity is at least an order of magnitude less than the conductivity of the first HSU sediments.

\section{Fourth Hydrostratigraphic Unit}

The fourth HSU underlies the third HSU and, based on Well Driller's Reports of water supply wells near the LEHR facility, 
is composed of sand and gravel-size sediments. It ranges from about 20 to 50 feet in thickness, is laterally continuous on a regional scale, and represents the second major aquifer in the Davis area. Specific information on the hydraulic conductivity of the fourth HSU is lacking, though Olmsted and Davis (1961) report that the yield factor ${ }^{4}$ of Tehama Formation aquifers in the general area of Davis is less than a tenth that of the sand and gravel of the overlying alluvium-fan deposits, i.e. the second HSU. Based on this observation, the hydraulic conductivity of the forth HSU may be an order of magnitude less than the conductivity of the second HSU sediments.

OCCURRENCE AND MOVEMENT OF GROUND WATER

Evaluation of the occurrence and movement of ground water at the LEHR facility incorporates an analysis of ground water elevation measurements, ground water and surface water chemistry, HSU physical properties and stratigraphic relationships, and local consumptive use of ground water. From a regional perspective, ground water recharge is derived from the infiltration of rainfall, surface water, and excess applied irrigation water; ground water discharge is via pumping for domestic, municipal and agricultural use.

\section{Eirst HSU}

Ground water in the first HSU is derived from two primary sources; infiltration of surface waters and the vertical movement of ground water from the underlying second HSU. Surface waters include rainfall runoff, stream flow in Putah Creek, and excess irrigation water applied to farm land. The predominant direction of ground water movement within the first HSU is vertical,

\footnotetext{
${ }^{4}$ specific capacity divided by the aquifer thickness multiplied by 100.
} 
flowing to the underlying second HSU during the irrigation season and return flow from the second HSU during the remainder of the year. In addition to the movement of ground water to and from the second HSU, surface waters percolate through the vadose zone portion of the HSU to the saturated portion.

Ground water elevation in the first HSU fluctuates seasonally by up to 35 feet primarily in response to extraction of water from the second HSU. Ground water elevation reaches its maximum usually in April of each year immediately prior to the onset of the local irrigation season. Once local agricultural irrigation begins, the elevation of ground water in the first HSU steadily declines throughout the duration of the pumping season. When local irrigation ceases, usually by mid-August, the elevation of ground water in the first HSU steadily increases until the onset of the next irrigation season. The seasonal decline of ground water elevation in the first HSU represents a transfer of 1.5 to 3 acre feet/acre $(500,000$ to $1,000,000$ gallons $)$ of water to the second HSU.

\section{Second HSU}

Ground water in the second HSU is derived from the release of water from the overlying first HSU and the direct infiltration of surface waters in areas (west of LEHR and associated with the course of Putah Creek) where the fine-grained first HSU is absent. Second HSU ground water discharges to pumping wells, flows to the fourth HSU via the annular space of wells completed in both aquifers, and, in the absence of agricultural pumping, recharges the overlying first HSU.

On a regional scale, the direction of ground water flow in the second HSU is to the east and southeast. However, because the second HSU provides ground water to most of the domestic, 
agricultural, and municipal wells in the Davis area, the direction of flow can vary by as much as $180^{\circ}$ from place to place or on a seasonal time frame. Data obtained from HSU2 monitoring wells in 1995 at the LEHR facility indicate that HSU2 ground water flow at the site is east northeasterly and that local agricultural pumping can induce deviations from the normal flow direction of up to $30^{\circ}$ daily. The northeasterly ground water flow at the LEHR site is a consequence of continual recharge from Putah Creek.

\section{Third HSU}

The third HSU is considered to be "non water bearing" in the sense that it will not yield usable quantities of water to wells. As a result, scant information is available to draw conclusions relating to its hydraulic properties. Davisson and Criss (1993) suggest, based on isotopic analyses of ground water from area water supply wells, that leakage through the third HSU occurs. However, this leakage, to some unknown extent, occurs as a consequence of the many wells in the area which interconnect the second and fourth HSUs.

\section{Fourth HSU}

Based on the relatively rapid recovery of water levels in wells which are completed in the fourth HSU, beginning at the end of the irrigation season and prior to winter rainfall, ground water in the fourth HSU is derived primarily from lateral flow as opposed to vertical flow. The area of ground water recharge is along the eastern flank of the Coast Range where the Tehama Formation is exposed or overlain by a thin veneer of more recent alluvial sediments. 
From a regional perspective, ground water flow in the fourth HSU is easterly. However, during the irrigation season the flow can be in any direction and capable of changing significantly from one day to the next. Unlike the second HSU which demonstrates small shifts in flow direction at the site on a daily basis, the fourth HSU is not affected by nearby recharge from Putah Creek which moderates pumping stresses in the second HSU.

\section{STABLE ISOTOPE ANALYSES}

During the May and August 1995 quarterly ground and surface water sampling activities, water samples from site monitoring wells and surface water sampling locations were collected for oxygen $\left({ }^{18} \mathrm{O} /{ }^{16} \mathrm{O}\right)$, nitrogen $\left({ }^{15} \mathrm{~N} /{ }^{14} \mathrm{~N}\right)$ and hydrogen $\left({ }^{1} \mathrm{H} /{ }^{2} \mathrm{H}\right)^{5}$. stable isotope analyses. The samples were analyzed via isotope-ratio mass spectrometry by the Center for Isotope Geochemistry at Lawrence Berkeley National Laboratory. Table 2 presents a summary of the stable isotope analyses. Figure 5 and 6 show the HSU1 and HSU2 monitoring well locations, respectively. Based on the two data sets, tentative conclusions and inferences may be drawn with regard to the hydrogeologic environment at the site. However, additional data sets are needed to refine and clarify these conclusions and validate the inferences.

The stable isotope ratios of oxygen and hydrogen provide a direct means for identifying ground water sources. Waters of different origins (or histories) acquire different hydrogen and oxygen isotopic ratios due to the variable mass of individual water molecules and the subsequent fractionation of the water during the processes of evaporation and condensation. Analyses of nitrogen isotopes in ground water are useful for discriminating

\footnotetext{
${ }^{5}{ }^{2} \mathrm{H}$ or deuterium is referred to as " $\mathrm{D}$ " in the remainder of this discussion.
} 
TABLE 2

\section{SUMMARY OF STABLE ISOTOPE ANALYSES \\ UCD/DOE LEHR FACILITY \\ DAVIS, CALIFORNIA}

\begin{tabular}{|c|c|c|c|c|c|c|}
\hline $\begin{array}{l}\text { Sample } \\
\text { Location } \\
\text { FIRST HSL }\end{array}$ & Oxygen 18 & $\begin{array}{l}\text { May } 1995 \\
\text { Deuterium }\end{array}$ & Nitrogen 15 & Oxygen 18 & $\begin{array}{l}\text { Aug } 1995 \\
\text { Deuterium }\end{array}$ & Nitrogen 15 \\
\hline UCD1-1 & -8.3 & -57 & 4.1 & -8.2 & -53 & 4.4 \\
\hline UCD1-4 & -6.1 & -40 & 6.4 & -6.2 & -45 & 5.8 \\
\hline UCD1-10 & -7.2 & -48 & 7.9 & -7.3 & -48 & 7.4 \\
\hline UCD1-11 & -6.6 & -47 & 6.0 & -6.6 & -45 & 5.0 \\
\hline UCD1-12 & -7.0 & -47 & 9.2 & -7.0 & -46 & 10.9 \\
\hline UCD1-13 & -6.2 & -45 & na & -6.4 & -41 & 9.4 \\
\hline UCD1-18 & -5.9 & -40 & 8.4 & -6.2 & -42 & 6.6 \\
\hline UCD1-19 & -7.3 & -46 & 4.9 & -7.6 & -48 & 4.6 \\
\hline UCD1-20 & -8.0 & -57 & 5.8 & -8.1 & -53 & 6.8 \\
\hline UCD1-21 & -7.0 & -47 & 8.9 & na & na & na \\
\hline UCD1-22 & -6.9 & -53 & 25.4 & -7.1 & -47 & 23.7 \\
\hline UCD1-23 & -6.4 & -45 & 8.9 & -6.4 & -43 & 8.8 \\
\hline UCD1-24 & -7.0 & -49 & 7.6 & na & na & na \\
\hline
\end{tabular}

SECOND HSU

UCD2-7

UCD2-14

UCD2-15

UCD2-16

UCD2-17

\begin{tabular}{ll}
-5.5 & -38 \\
-5.8 & -42 \\
-4.5 & -34 \\
-4.8 & -36 \\
-4.5 & -33 \\
\hline
\end{tabular}

\begin{tabular}{cc|ccc|}
-38 & 10.6 & -5.9 & -40 & 9.4 \\
-42 & 9.8 & -6.4 & na & na \\
-34 & 4.4 & -5.7 & -35 & 7.1 \\
-36 & 5.7 & -4.9 & -38 & 4.6 \\
-33 & 10.1 & -4.7 & -39 & 6.0 \\
\hline
\end{tabular}

SURFACE WATER

\begin{tabular}{l|lll|lll|} 
PCU & -5.3 & -43 & 6.1 & -4.6 & -34 & 6.5 \\
STPO & -7.9 & -56 & 14.7 & -7.8 & -62 & 8.0 \\
PCD & -5.7 & -42 & 5.6 & -5.1 & -38 & 6.6 \\
\hline
\end{tabular}

na $=$ not analyzed 


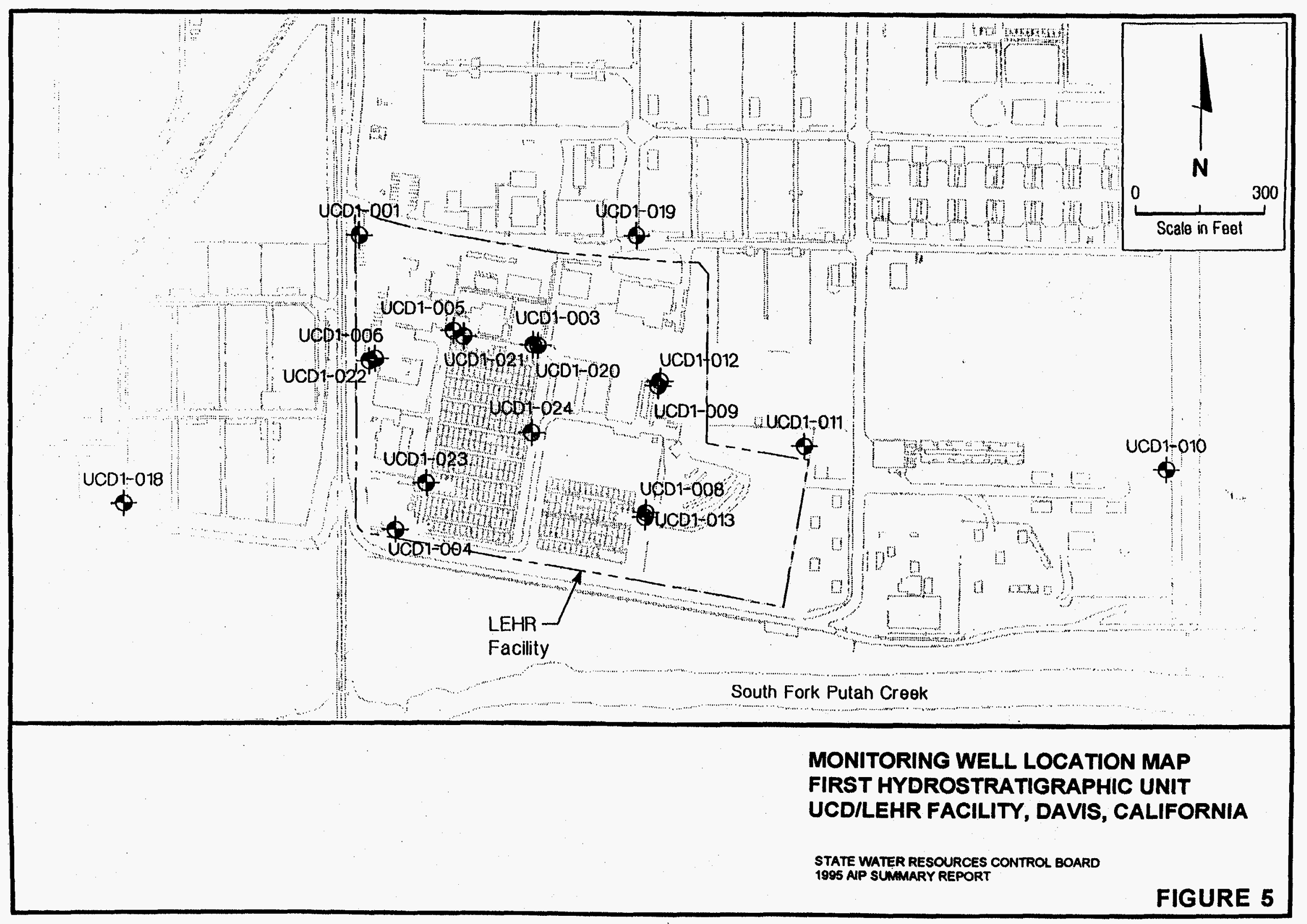




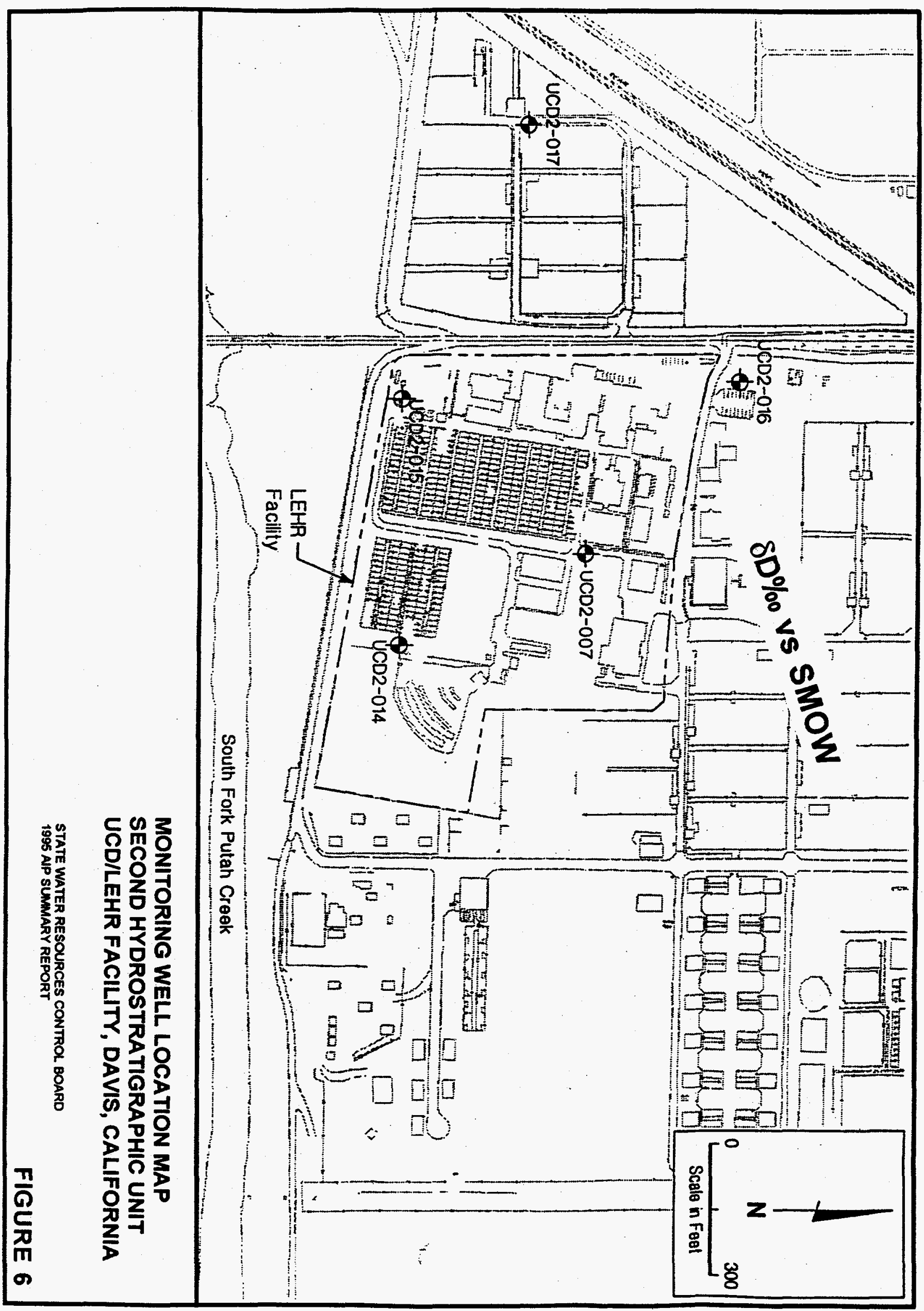


among nitrate sources. Nitrate derived from human and animal wastes typically has $\delta{ }^{15} \mathrm{~N}$ values in the range of 10 to $20 \%$, nitrate derived from natural organic material in soil has $\delta{ }^{15} \mathrm{~N}$ from 3 to $8 \%$, and nitrate derived from commercial fertilizers has $\delta{ }^{15} \mathrm{~N}$ from -2 to $4 \%$ (Aravena, Evens and Cherry, 1993).

\section{Spatial and Temporal stable oxygen/Hydrogen Isotope Variations in} Ground Water

Graphs of the $\delta \mathrm{D}$ vs. $\delta^{18} \mathrm{O}$ values of the May and August water samples are presented in Figures 7 and 8 , respectively. These graphs can be used to distinguish the various origins of ground and surface waters at the LEHR facility and provide insights to the dynamics of the site hydrologic environment.

Most site waters analyzed lie along or to the right of the global meteoric water line (MWL) which has a slope of 8 (Craig, 1961). The HSU2 isotopic values for May lie along a surface evaporation trend that extrapolates back to the MWL at the implied average value for meteoric precipitation $\left(\delta D=-50 \%, \delta^{18} O=-7.5 \%\right)$ in the southwestern Sacramento Valley (Davisson \& Criss, 1993).

The slope of 5 for HSU2 waters is appropriable to surface evaporation under temperatures and humidities characteristic of the Sacramento Valley (Ibid) and approximates the trend for Putah Creek water reported by Davisson and Criss.

The majority of HSUl waters for May define a rough linear trend with a slope of 3.2. Their lower slope is explained if ground water from local meteoric water recharge has mixed with Putah creek recharge water that has undergone evaporation. Two notable exceptions to the trend are the plots of $\delta \mathrm{D} / \delta^{18} \mathrm{O}$ values for wells $\operatorname{UCD} 1-1$ and $\operatorname{UCD} 1-20 \quad\left(\delta^{18} \mathrm{O}=-8.0\right.$ and $-8.3 \%$ respectively $)$ and $\mathrm{UCD} 1-4$ and $\mathrm{UCD}-18\left(\delta^{18} \mathrm{O}=-6.1\right.$ and $-5.9 \%$ respectively $)$. 


\section{Oxygen - Hydrogen Isotope Ratios May 1995}

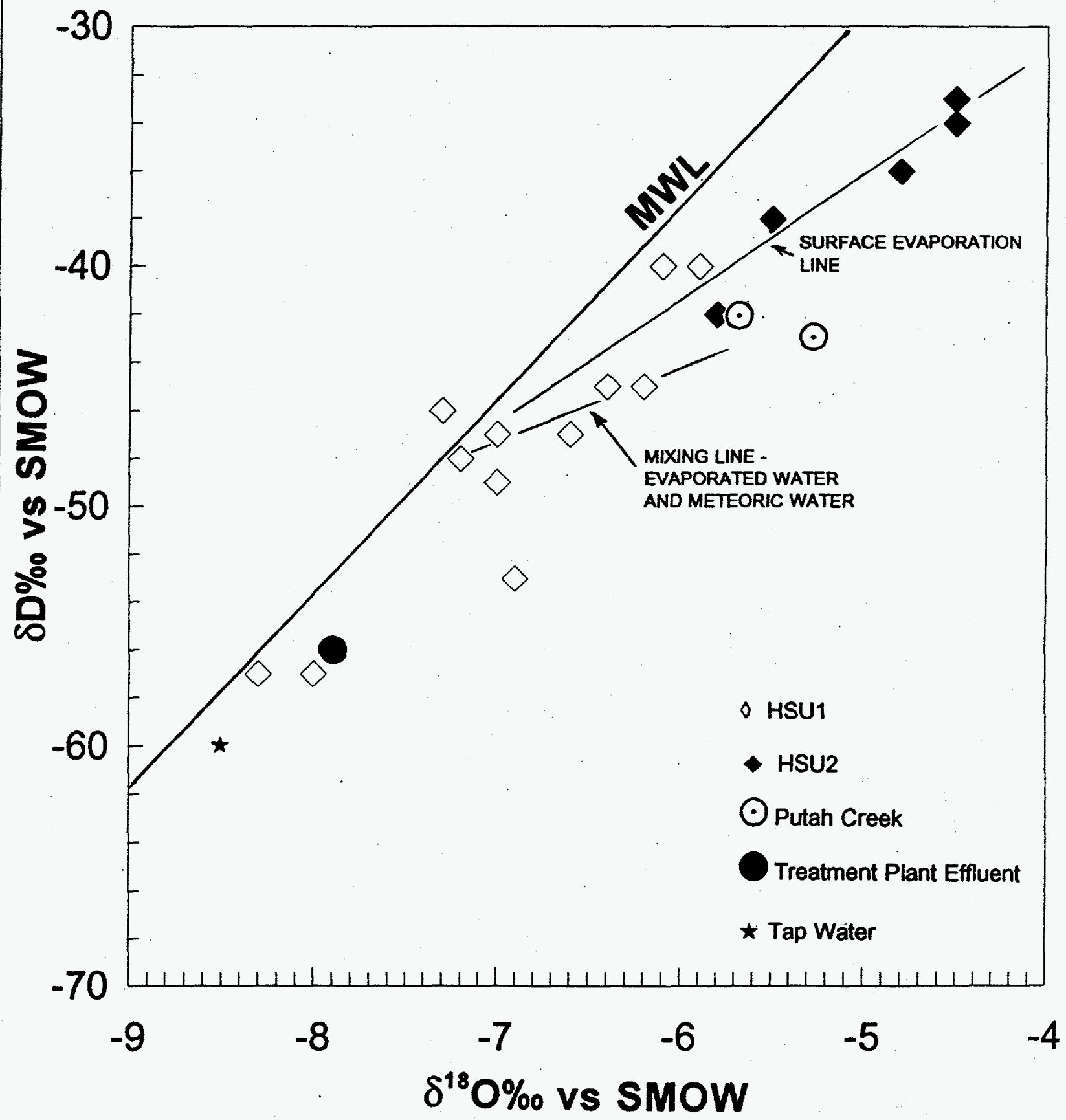

State Water Resources Control Board 1995 AIP Summary Report 


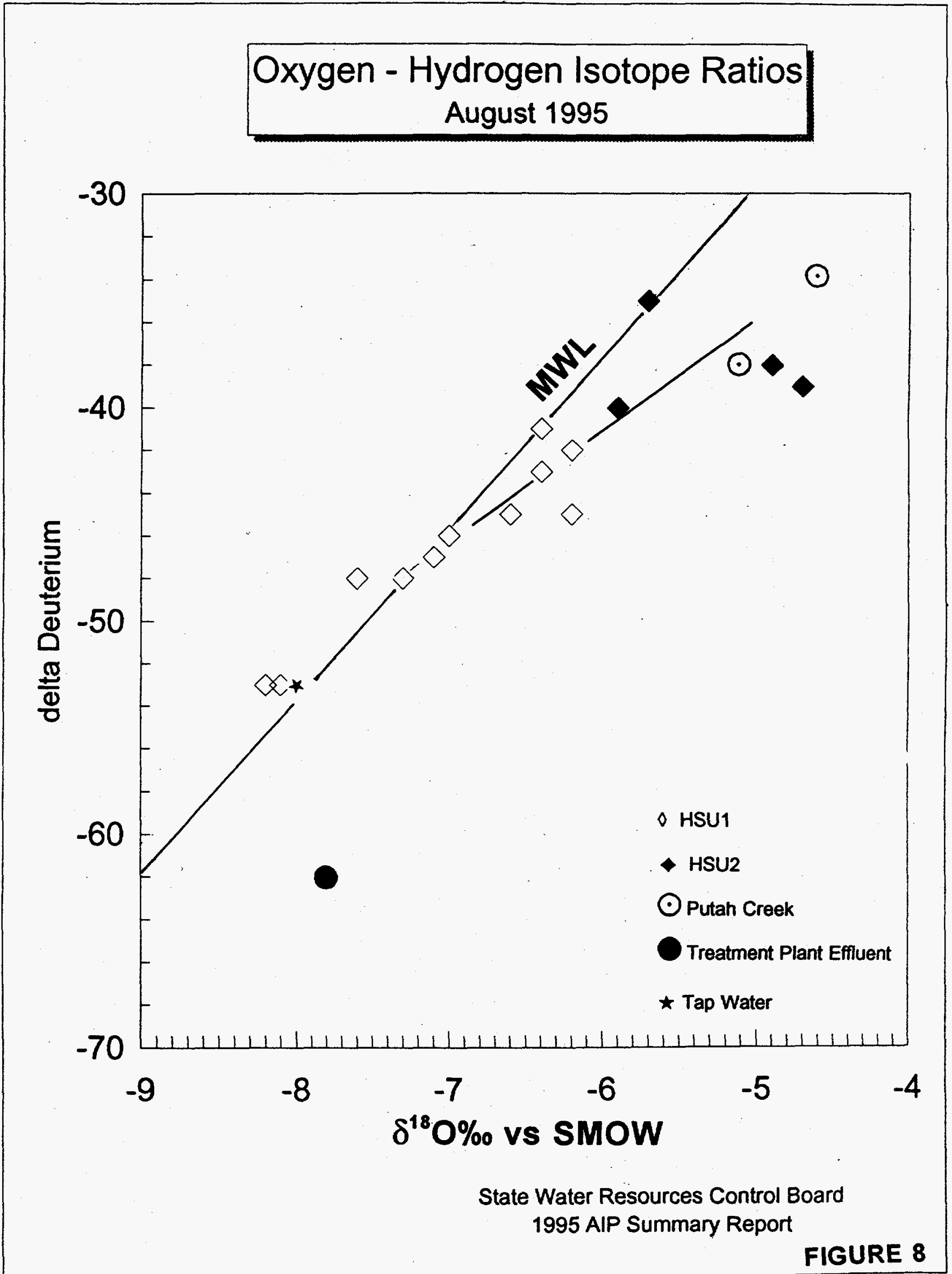




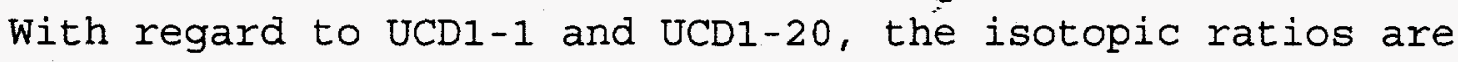
consistent with those of waters used at the facility and that. which is discharged from the UC Davis sewage treatment plant to Putah Creek. This similarity suggests that the four waters have a common source separate from the meteoric and surface water sources inferred for the remainder of the site's ground and surface water samples. Davisson ana Criss (1993) documented that deep ground water (greater than 750 feet) is depleted in ${ }^{18} \mathrm{O}$ relative to shallower ground water and thus is isotopically distinct. This finding indicates that ground water in the two monitoring wells and water from the UC Davis sewage treatment plant is derived primarily from the deep water supply wells which service the campus and the LEHR facility. May, 1995 ground water from wells UCDI-4 and UCD1-18 exhibit isotopic ratios more characteristic of HSU2 ground water and are discussed below in the context of HSU2 isotope variability.

A plot of HSUI $\delta^{18} O$ values vs. distance from the east-west trend of Putah Creek (Fig. 9) demonstrates the relative proportions of meteoric water recharge and Putah Creek derived recharge in the first HSU. Water in wells furthest from the creek exhibit $\delta^{18} \mathrm{O}$ values and isotope ratios approaching those of meteoric water while water in wells nearest the creek have values and ratios approaching Putah Creeks "evaporated" surface water. Note that the $\delta^{18} \mathrm{O}$ values for ground water from wells UCD1-1 and UCD1-20 which are representative of facility water, plot well below the trend Iine.

Comparing the May, 1995 isotope ratios with those for August reveals that the waters, with the exception of UCDI-4 and UCD1-18, shift toward the MWL. This shift suggests that waters sampled in August have a greater proportion of meteoric water than those sampled in May. This phenomena suggests that there is minimal vertical mixing of ground water in the first HSU owing to 


\section{HSU1 delta 18 O vs. Distance From Putah Creek May 1995 Ground and Surface Water}

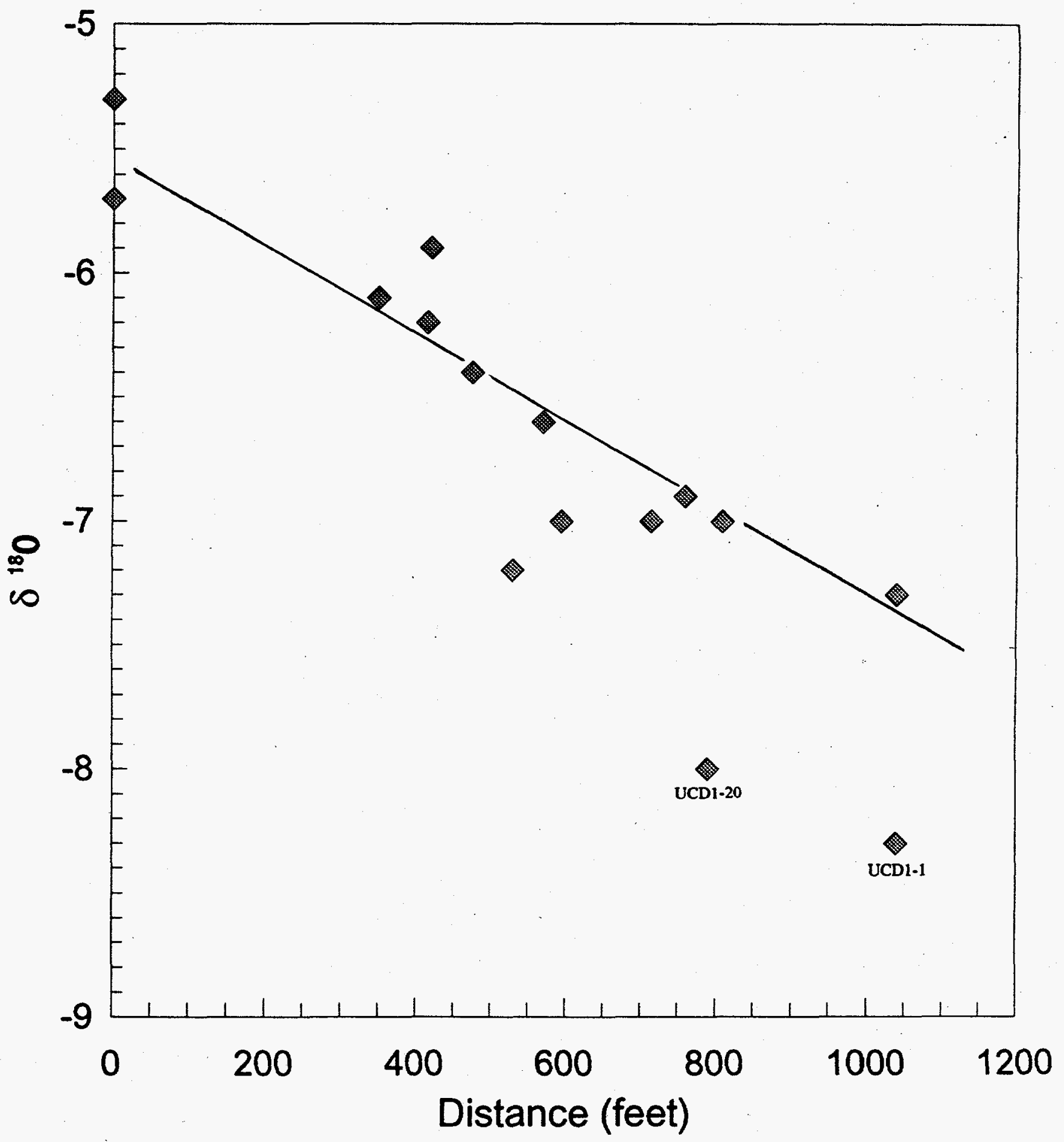

State Water Resources Control Board 1995 AIP Summary Report 
its relative homogeneity and low conductivity.

The May to August, 1995 shift in HSU2 ground water (including UCD1-4 and UCD1-18 water) isotope ratios tend to be in the direction of ${ }^{18} \mathrm{O}$ depletion along the surface water "evaporation" line while Putah Creek waters become enriched with ${ }^{18} \mathrm{O}$. The enrichment of Putah Creek water likely reflects increased evaporation rates as summer progresses. The apparent depletion of ${ }^{18} \mathrm{O}$ in HSU2 ground water is likely related to the seasonal ${ }^{18} \mathrm{O}$ shifts in Putah Creek water (Davisson and Criss [1993] report $\delta{ }^{18} \mathrm{O}$ values for Putah Creek water range from -3.1 to $-5.7 \%$ ). The timing of the shift is out of phase with inferred Putah Creek shifts due to the much slower water flow rate in the aquifer.

Spatial and Temporal Stable Nitrogen Isotope Variations in Ground Water

Ground water samples analyzed in 1995 for nitrogen isotopes had $\delta{ }^{15} \mathrm{~N}$ values which ranged from 4.1 to $25.4 \%$ (Table 2). Putah Creek water samples provided $\delta{ }^{15} \mathrm{~N}$ values ranging between 5.6 and $6.6 \%$, the sewage treatment plant effluent measured 14.7 and $8.0 \%$, while tap water yielded a value of $6.7 \%$.

Concentrations of nitrate $\left(\mathrm{NO}_{3}\right)$ in first $\mathrm{HSU}$ site ground water range from less than half to more than seven times the state drinking water standard $(45 \mathrm{mg} / \mathrm{L})$. The highest concentrations are associated with the locations of the dog pens and the three inactive landfill units. Nitrogen isotope analyses of first HSU ground water provides a strong animal waste signature $\left(\delta{ }^{15} \mathrm{~N}=24 \%\right.$ ) in the vicinity of the septic tank that serviced the animal hospital but moderate to weak signatures $\left(\delta^{15} \mathrm{~N}=7.9\right.$ to $\left.10.9 \%\right)$ in the area of highest concentrations. The greatest shifts in $\delta{ }^{15} \mathrm{~N}$ values from May to August occurred in samples from wells UCD1-12 (9.2 to $10.9 \%)$ and UCD1-18 (8.4 to $6.6 \%)$. In the case of well 
UCD1-12, the $\delta{ }^{15} \mathrm{~N}$ shift was accompanied with an increase in the nitrate concentration from $260 \mathrm{mg} / \mathrm{L}$ to $324 \mathrm{mg} / \mathrm{L}$. Based on the interpretation drawn from oxygen/hydrogen isotope data that ground water sampled in the summer has a significant content of meteoric water infiltrated during a preceding winter, the $\delta{ }^{15} \mathrm{~N}$ shift and concentration increase represent "fresh" leachate from a vadose zone source of animal waste in the immediate vicinity of the well. The $\delta{ }^{15} \mathrm{~N}$ shift in UCD1-18 water was accompanied with a moderate increase in nitrate concentration (86 to $104 \mathrm{mg} / \mathrm{L}$ ). These data suggest that the nitrate is derived in part, from naturally occurring organic material. The origin of the presumed source is likely associated with Putah Creek.

Concentrations of nitrate in second HSU site ground water range from less than half to about two times the state drinking water standard. Like ground water in the first HSU, the highest concentrations are associated with the locations of the dog pens and the inactive landfill units. Nitrogen isotope analyses of these ground waters provide a moderate animal waste signature $\left(\delta{ }^{15} \mathrm{~N}=9.4\right.$ to $10.6 \%$ ) consistent with the presumed nitrate source at the site. Shifts in the $\delta{ }^{15} \mathrm{~N}$ values from May to August are greatest in the two up-gradient HSU2 monitoring wells with UCD2-15 water being enriched with ${ }^{15} \mathrm{~N}$ (4.4 to $7.1 \%$ ) while UCD2-17 becomes depleted $(10.1$ to $6.0 \%)$. While the nitrate concentrations in the ground water do not change significantly ( 7 to $12 \mathrm{mg} / 1$ ) in either well, the variability in the $\delta^{15} \mathrm{~N}$ values may suggest the presence of multiple nitrate sources and alludes to the dynamism of the local hydrogeologic environment and the influence upon it by Putah Creek.

CONTINUOUS WATER LEVEL ELEVATION MEASUREMENTS

To better characterize the hydrogeologic environment at the LEHR facility, continuous water level recorders (Stevens ${ }^{\circ}$ Type F, 
model 68) were placed on three HSU2 monitoring wells (UCD2-7, -14, and -15) in June. The recorders provided information relating to the daily water level fluctuations in the second HSU and a means of assessing temporal directional changes in ground water flow. In July, recorders were installed on a HSU1/HSU2 well pair (UCD $1-13$ and 2-14) to gauge the vertical hydraulic gradient between the two HSUs.

Figure 10 represents daily minimum/maximum water level elevations in the three HSU2 monitoring wells in June. Data indicate that for the period shown (which corresponds to the local irrigation season), water levels fluctuate up to two feet on a daily basis. Water levels are highest in the morning prior to the initiation of crop irrigation and lowest in the evening as work in the farm fields ends and the pumps are turned off. Daily fluctuations in the ground water elevation were consistently greatest in well UCD2-14. This phenomenon implies a vacillating HsU2 ground water flow direction which daily varies in direction by up to $30^{\circ}$ during the irrigation season. Figure 11 represents water level elevation data obtained in July from the HSU1/HSU2 well pair. The data show that while the water level in the second HSU fluctuates daily in response to local irrigation demands, the water level in the first HSU steadily declines in response to the pressure differential between the two HSUs. Based on the. construction of the two wells and the observed differences in water level elevations, the vertical hydraulic gradient in the vicinity of the well pair ranges from a low of 0.032 to a high of 0.11 . From these hydraulic gradients and the corresponding rate of water level decline in the first HSU, the vertical hydraulic conductivity of the first HSU is estimated to range between $5.5 \mathrm{x}$ $10^{-5}$ and $2.0 \times 10^{-4} \mathrm{~cm} / \mathrm{sec}$ (Appendix $\mathrm{A}$ ).

The irrigation season decline in the HSUl water level represents a release of an estimated 1.5 to 3 acre feet per acre of ground 


\section{Groundwater Elevation Fluctuations Second Hydrostratigraphic Unit}

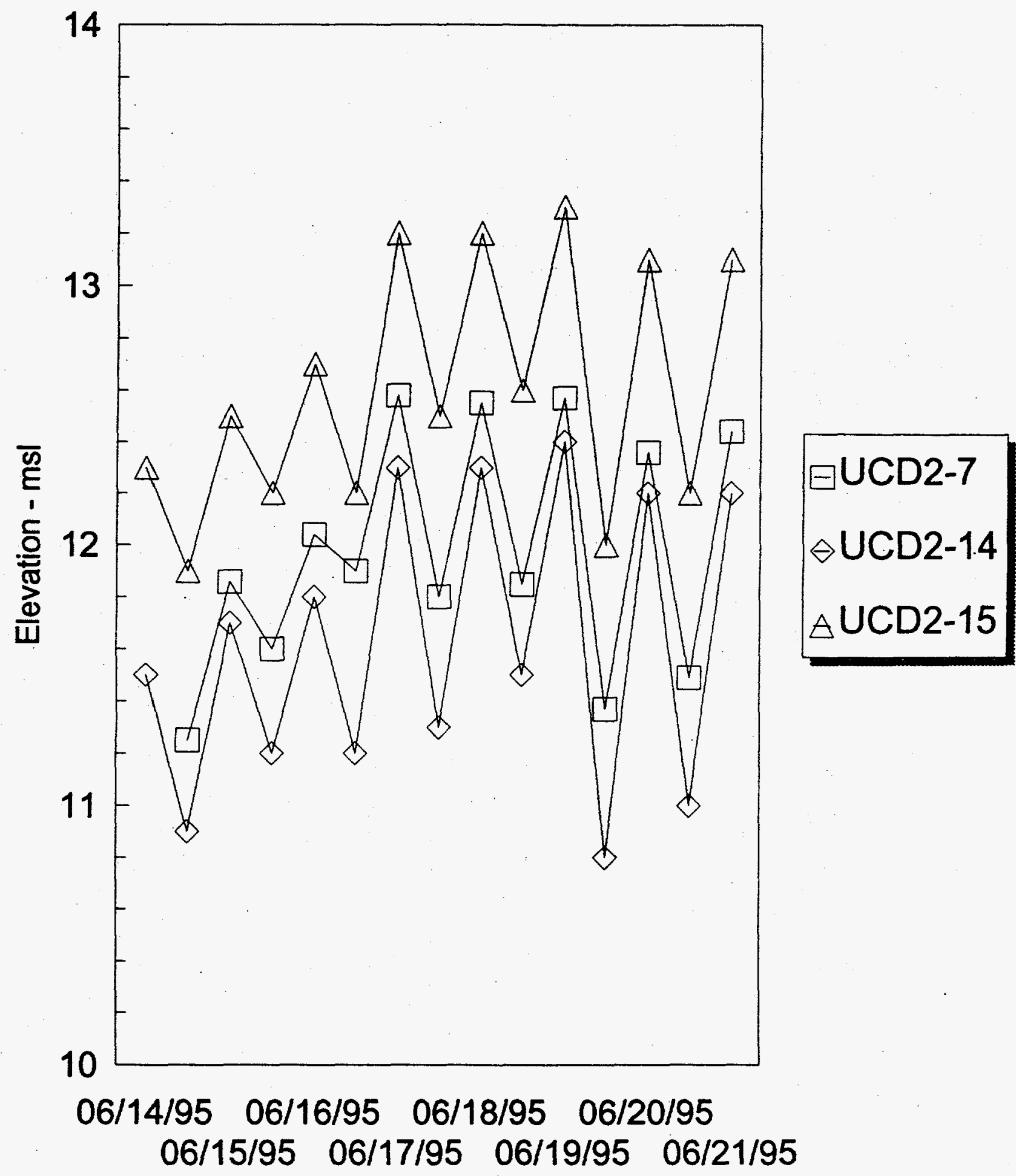

State Water Resources Control Board 1995 AIP Summary Report 


\section{Groudwater Elevation Fluctuations}

First and Second Hydrostratigraphic Units

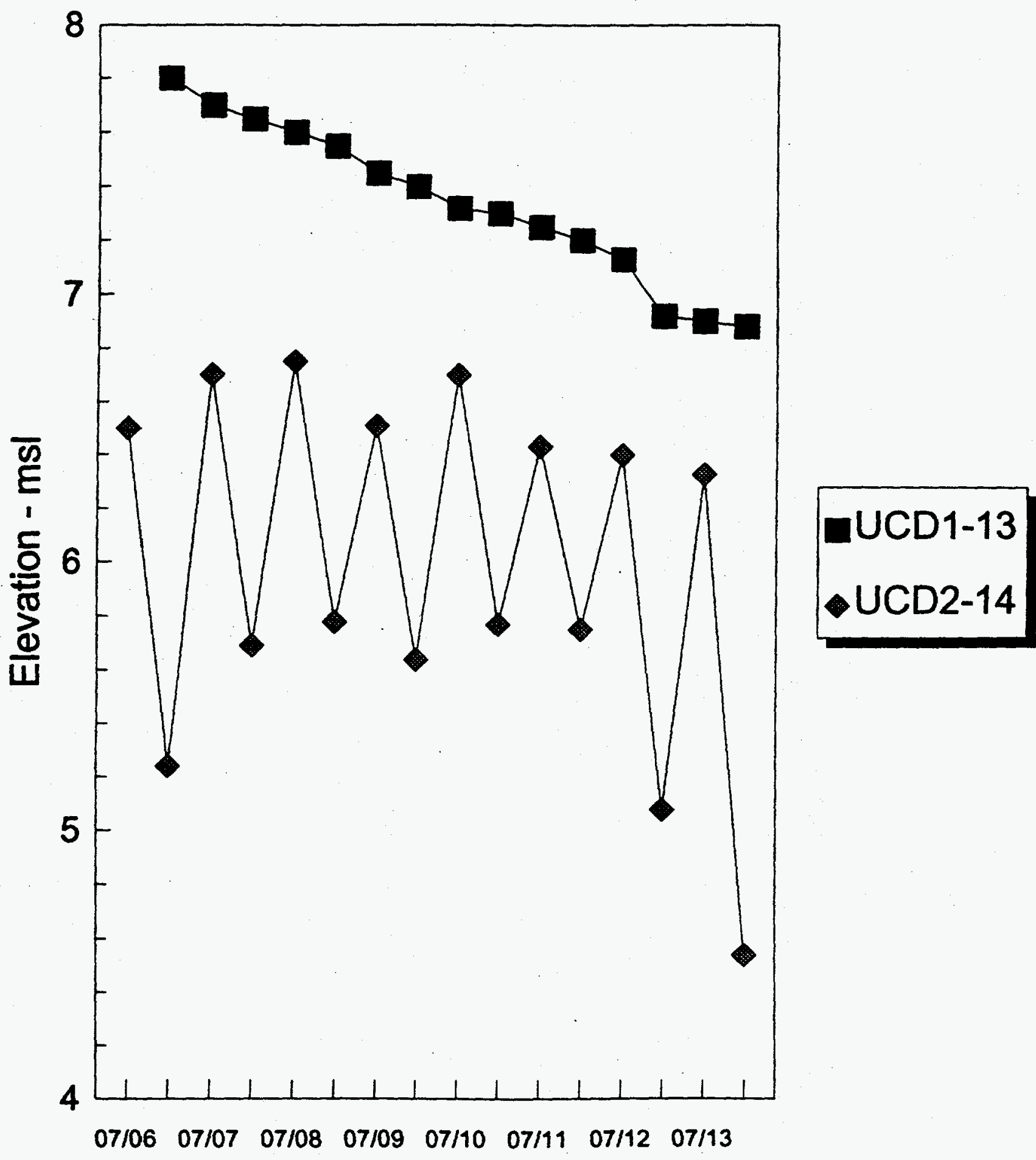


water to the second HSU. This "added" water likely represents about half of the volume of ground water pumped from the second HSU during the course of the irrigation season.

GROUND WATER QUALITY

In response to the suspicion that constituents of concern present in site ground water had migrated off-site, AIP staff located all identifiable water supply wells within three miles to the east and northeast of the site (Appendix B) to assess potential threats to human health and safety. Subsequently, ten of the wells within two miles of the site (six domestic and four agriculture supply wells) were sampled by AIP staff and the water analyzed for general minerals, nitrate, chromium, tritium, and/or volatile organic compounds (VOCs). A summary of the ground water sample analyses are presented in Table 3 .

An evaluation of the ground water analytical results from the ten water supply wells provides the following conclusions:

- Second HSU ground water exceeds state drinking water standards for electrical conductivity, total dissolved solids, and nitrate; chromium concentrations approach or slightly exceed state drinking water standards. Most of the domestic supply wells sampled derive their water from the second HSU.

- The poor quality of second HsU ground water is likely a consequence of local agricultural practices rather than waste disposal practices at the LEHR facility.

- VOCs originating from the LEHR facility are present in second HSU ground water at least 1500 feet beyond the UC Davis property boundary; the origin of low levels of vocs 
TABLE 3

STATE WATER RESOURCES CONTROL BOARDIAGREEMENT-IN-PRINCIPAL SUMMARY OF ANALYTICAL RESULTS

NOVEMBER 1995 GROUNDWATER SAMPLING OF OFF-SITE WELLS

EAST AND NORTHEAST OF LEHR, NEAR DAVIS, CALIFORNIA

\begin{tabular}{|c|c|c|c|c|c|c|c|}
\hline \multirow{2}{*}{$\begin{array}{l}\text { TEST } \\
\text { PARAMETER } \\
\end{array}$} & \multirow[b]{2}{*}{ UNITS } & \multicolumn{3}{|c|}{ DETECTION } & \multicolumn{3}{|c|}{ WELL\# } \\
\hline & & $\mathrm{MCL}$ & LIMIT & $14 Q 2$ & $15 \mathrm{~K} 3$ & $22 N$ & $23 \mathrm{H}$ \\
\hline Sulfate & $m g /$ & 250 & 0.5 & 94 & 74 & 41 & 96 \\
\hline Chloride & $m g / 1$ & 250 & 1 & 48 & 38 & 22 & 37 \\
\hline $\mathrm{pH}$ & Std.Units & & & 7.3 & 7.3 & 7.3 & 7.3 \\
\hline Alkalinity(CaCO3) & $m g n$ & & 2 & 630 & 530 & 340 & 580 \\
\hline Alkalinity(HCO3) & $m g n$ & & 2.4 & 770 & 650 & 410 & 710 \\
\hline EC & umhos/cm & 900 & 1 & 1490 & 1280 & 783 & 1390 \\
\hline TDS & $m g n$ & 500 & 15 & 880 & 740 & 440 & 830 \\
\hline Nitrate(NO3) & $m g / n$ & 45 & 0.09 & 88 & 66 & 18 & 53 \\
\hline Cakium & $m g n$ & & 0.1 & 65 & 45 & 48 & 76 \\
\hline Copper & $m g n$ & 1 & 0.01 & ND & ND & 0.014 & ND \\
\hline Iron & $m g n$ & 0.3 & 0.03 & 0.14 & 0.04 & ND & ND \\
\hline Magnesium & $m g n$ & & 0.1 & 140 & 100 & 66 & 100 \\
\hline Manganese & $\mathrm{mg} / 1$ & 0.05 & 0.005 & ND & ND & ND & ND \\
\hline Potassium & $m g /$ & & 0.5 & 1.2 & 1 & ND & ND \\
\hline Sodium & $\mathrm{mg} /$ & & 0.5 & 96 & 96 & 42 & 120 \\
\hline Zinc & $m g n$ & 5 & 0.005 & 0.076 & 0.039 & ND & ND \\
\hline Chrome VI & $m g n$ & 0.05 & 0.01 & 0.042 & NS & NS & 0.098 \\
\hline Tritium & pCn & 20,000 & 300 & ND & NS & NS & ND \\
\hline
\end{tabular}

MCL = maximum contaminent level (STATE DRINKING WATER STANDARD)

ND $=$ not detected $\quad N S=$ not sampled 
TABLE 3 (continued)

STATE WATER RESOURCES CONTROL BOARD/AGREEMENT-IN-PRINCIPAL

SUMMARY OF ANALYTICAL RESULTS

NOVEMBER 1995 GROUNDWATER SAMPLING OF OFF-SITE WELLS

EAST AND NORTHEAST OF LEHR, NEAR DAVIS, CALIFORNIA

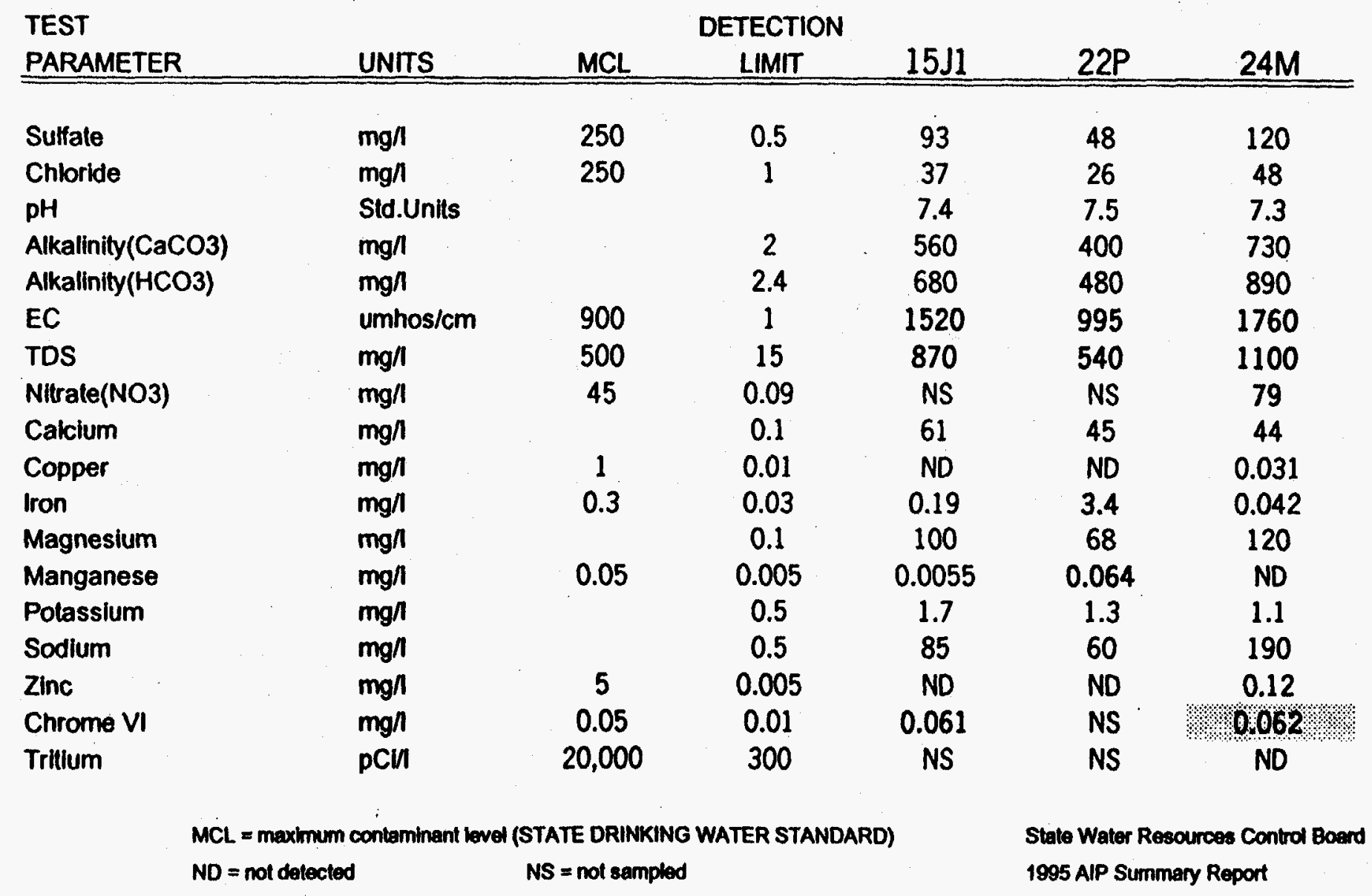


TABLE 3 (continued)

SUMMARY OF ANALYTICAL RESULTS

NOVEMBER 1995 GROUNDWATER SAMPLING OF OFF-SITE WELLS

EAST AND NORTHEAST OF LEHR, NEAR DAVIS, CALIFORNIA

VOLATILE ORGANIC COMPOUNDS - EPA Method 601

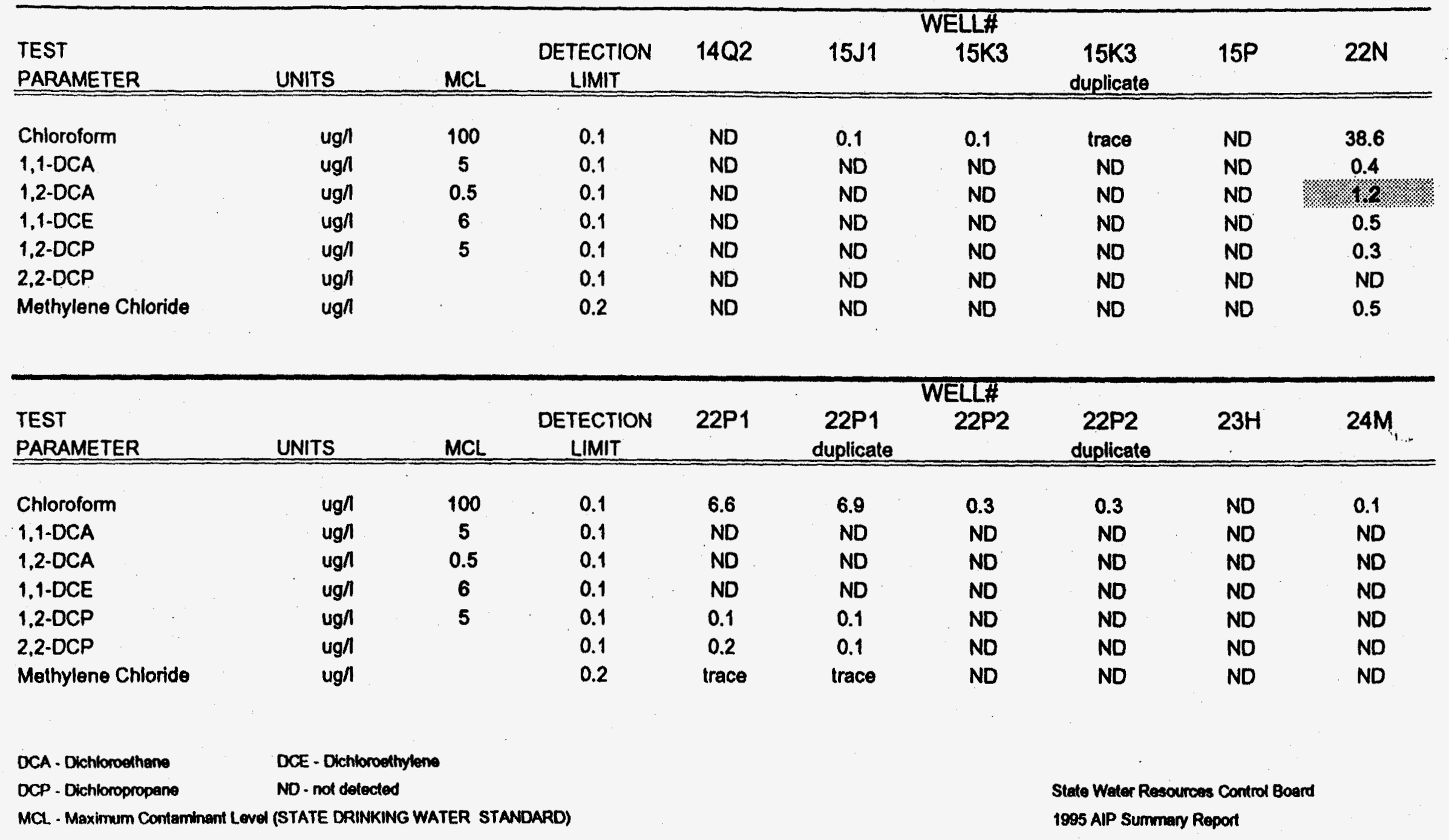


detected in some of the domestic supply wells is suspected to be associated with septic tanks.

\subsection{ADEQUACY OF GROUND WATER MONITORING SYSTEM}

Fundamental questions relating to the adequacy of ground water monitoring systems are, 1) does the monitoring well network sufficiently define the extent of affected ground water so that risk to public health and safety and the environment can be assessed? and 2) do the sampling and analytical procedures provide reliable data? In considering the monitoring system at the site, one must focus on the second HSU by virtue of the fact that it represents the primary pathway for pollutant migration. The extent of pollution in the first HSU is important only as a pollution source for the second HSU. Sampling and analytical procedure validation was addressed by submitting split samples to an independent laboratory for analyses and comparison of the results with sample results from the DOE contract laboratory.

GROUND WATER MONITORING WELLS

The distribution of pollutants in the second HSU is relatively well defined in the central and western portion of the facility Definition of pollution distribution in the eastern portion of the site and beyond is lacking. While water quality data from hydropunch activities performed over the past few years provide a "snapshot" of the approximate magnitude of the problem in this portion of the site, monitoring wells are needed here and offsite to assess temporal changes in pollutant concentrations, evaluate ground water flow direction and changes in direction, and, in the event that remedial ground water activities commence, to evaluate the effectiveness of those activities. 
Hydropunch water quality data for the second HSU indicates that the plume of VOCs emanating from the vicinity of monitoring well HSU1-12 has crossed the eastern UC Davis property line. Water samples from the Nishi irrigation wells (22N and $22 \mathrm{P} 2^{6}$ ) and an Alonzo irrigation well (22P1) indicate that these wells, when operational, extract a portion of the plume from the second HSU. When these wells are not operational, suspected head differentials between the second and forth HSUs and the construction of the wells, combine to present conditions conducive for the flow of affected water from the second HSU to the forth HSU. Based on this premise, a monitoring well completed in the forth HSU is needed to assess presumed impact to that water bearing zone. Additional monitoring wells will be needed if the impact to the forth HSU is found to be significant.

\section{SAMPLING VALIDATION}

One of the functions of the AIP is to verify monitoring results obtained by the DOE contract laboratory in the analysis and reporting of environmental samples. The validation method consisted of obtaining split samples from the site during sampling activities and rubmitting them, along with various quality control samples, to an independent laboratory(s) for analyses. The sample results from the DOE contract laboratory and the AIP laboratory were then compared for consistency of reported results.

During the spring sampling round (May 1995), AIP staff from DHS and the SWRCB collected split samples from selected site monitoring wells and the three surface water sampling points in Putah Creek. Analyses for general minerals, metals, and

${ }^{6}$ see Appendix B for well locations. 
radionuclides were performed by the DHS Sanitation and Radiation Laboratory; analyses for chlorinated volatile organic compounds were performed by the Central Valley Regional water Quality Control Board. The samples collected by the DOE contractor were analyzed by their contract laboratory, Lockheed, and reported in the 1995 winter quarter monitoring report (PNL 1995).

A comparison of the Lockheed/AIP May 1995 sample results for general minerals and metals is herein deferred because DHS did not provide SWRCB staff the documentation with which to evaluate the quality of the sample results. A comparison of positive chlorinated VOC sample results is presented in Table 4 . In addition to these samples, analyses of water by the two laboratories from well UCD1-18 and the upstream sampling point in Putah Creek (PCU) both reported "non-detect" for all parameters tested.

A review of the data presented in Table 4 shows that there is close agreement in most sample results for constituents detected at concentrations of about $1 \mathrm{ug} / 1$ or greater from the Lockheed and RWQCB laboratories. For constituent concentrations in the range of 0.1 to $0.6 \mathrm{ug} / 1$ reported by the RWQCB laboratory, the "non-detects" reported by Lockheed are a consequence of their higher method detection limit of $1 \mathrm{ug} / 1$ as opposed to the RWQCB's limit of $0.1 \mathrm{ug} / 1$.

\subsection{SUMMARY, CONCLUSIONS AND RECOMMENDATIONS}

Past waste disposal practices at and adjacent to the LEHR facility have resulted in the release of chemical and radiologic constituents to shallow ground water beneath the site. As a consequence of the chemical characteristics of the constituents and the dynamism of the local ground water regime, the constituents have migrated to the first regional aquifer (HSU2) 
TABLE 4

COMPARISON OF LEHRIAIP SPRING QUARTER VOC SAMPLE RESULTS

all values as ugh

CONSTITUENT

CHLOROFORM

1.1-DICHLOROETHENE

TETRACHLOROETHENE

TRICHLOROETHENE

DIBROMOCHLOROMETHANE

METHYLENE CHLORIDE

BROMODICHLOROMETHANE

BROMOFORM

CHLOROTOLUENE

\begin{tabular}{|cc|cc|cc|cc|}
\hline UCD1-24 & \multicolumn{1}{c|}{ UCD1-23 } & UCD1-22 & UCD1-21 \\
\hline LOCKHEED & RWQCB & LOCKHEED & RWQCB & LOCKHEED & RWQCB & LOCKHEED & RWQCB \\
1.5 & 1.2 & 0.64 & 0.6 & ND & 0.2 & ND & 0.3 \\
ND & 0.4 & ND & ND & ND & ND & ND & ND \\
0.84 & 0.8 & ND & ND & ND & ND & ND & ND \\
ND & 0.3 & ND & ND & ND & ND & ND & ND \\
ND & ND & ND & ND & ND & ND & ND & ND \\
ND & ND & ND & ND & ND & ND & ND & ND \\
ND & ND & ND & ND & ND & ND & ND & ND \\
ND & ND & ND & ND & ND & ND & ND & ND \\
NR & ND & NR & ND & NR & ND & NR & ND \\
\hline
\end{tabular}

CONSTITUENT

CHLOROFORM

1,1-DICHLOROETHENE

TETRACHLOROETHENE

TRICHLOROETHENE

DIBROMOCHLOROMETHANE

METHYLENE CHLORIDE

BROMODICHLOROMETHANE

BROMOFORM

CHLOROTOLUENE.

PCD

\begin{tabular}{|cc|cc|}
\hline LOCKHEED & RWQCB & LOCKHEED & RWQCB \\
ND & O.1 & 2.2 & 2.5 \\
ND & ND & ND & ND \\
ND & ND & ND & ND \\
ND & ND & ND & ND \\
ND & 0.1 & 3.2 & 3.0 \\
ND & ND & ND & 2.5 \\
ND & ND & 2.6 & 3.1 \\
ND & ND & 1.8 & 2.0 \\
NR & ND & NR & 1.2 \\
\hline
\end{tabular}

ND = NOT DETECTED

$N R=$ NOT REPORTED

STATE WATER RESOURCES CONTROL BOARD 1995 AIP SUMMARY REPORT 
beneath the site. Ground water flow in the aquifer has resulted in the dispersal of some constituents to beyond the facility boundaries. Agricultural supply wells near the facility have afforded affected ground water in the first aquifer (HSU2) a pathway to the second aquifer (HSU4). The magnitude and extent to which the second aquifer has been affected is not presently known.

The existing ground water monitoring wells coupled with recent water quality data obtained via hydropunch technology, have sufficiently characterized the extent of pollution in the first HSU. The extent of pollution in the second HSU within the site boundaries, with the exception of the Landfill \#3 area has likewise been characterized; off-site delineation of affected ground water, however, is lacking.

The following recommendations are aimed at achieving two objectives: 1) providing a monitoring system which adequately defines the magnitude and extent of affected ground water and 2) providing additional data from which to further refine the site hydrogeologic conceptual model. The process of attaining the first objective will aid in the further refinement of the conceptual model while the second objective will provide information from which the monitoring system can be more completely evaluated.

- Various VOCs in HSU2 ground water are detected in water samples from irrigation water supply wells located up to 1500 feet down gradient of the UC Davis property boundary. HSU2 monitoring wells should be constructed at the eastern site boundary and off-site to quantify the impact and provide water level elevation data needed to characterize the ground water flow regime in this area. 
- Active and abandoned irrigation water supply wells within the suspected off-site plume afford passage of affected ground water from the second HSU to the fourth HSU. Monitoring weII(s) should be constructed off-site to gauge the magnitude of the impact on the fourth HSU and provide water level elevation data needed to characterize the ground water flow regime in this area.

- Nitrogen isotope analyses suggest the presence of multiple sources of nitrate at and near the facility. Water samples from domestic and agricultural supply wells with elevated concentrations of nitrate should be analyzed for nitrogen isotopes to evaluate potential sources including the possible link to identified LEHR facility sources.

- Oxygen/hydrogen isotope analyses imply that recharge from Putah Creek provides a strong hydraulic barrier to southerly ground water flow in the first HSU and is also a major source of second HSU ground water. Water samples from site monitoring wells and Putah Creek should be analyzed for oxygen/hydrogen isotopes quarterly for a period of one year to refine and clarify conclusions and validate inferences drawn from the two sampling episodes in 1995. 


\subsection{REFERENCES}

Araveba, R., Evens, M.L., and Cherry, J.L. 1993. Stable Isotopes of Oxygen and Nitrogen in Source Identification of Nitrate from Septic Systems. Ground Water v.31 No.2, MarchApril 1993.

Craig, H. 1961. Isotopic Variations in Meteoric Waters. Science 133, 1702-1703, 1961.

Department of Health Services (DHS), 1995. 1995 Annual Report, California Agreement in Principle. September 30, 1995.

Dames \& Moore. 1993. Phase II Characterization Report for the LEHR Environmental Restoration, University of California, Davis

Davisson, M.L., and Criss, R.E. 1993. Stable Isotope Imaging of a Dynamic Ground Water System in the Southwestern Sacramento Valley, California, USA. Journal of Hydrology, v.144, pp 213246 .

Olmsted, F.H. and Davis, G.H. 1961. Geologic Features and Ground-Water storage Capacity of the sacramento Valley, California. U.S. Department of the Interior, Geological Survey Water-Supply Paper 1497.

Pacific Northwest Laboratory (PNL). 1995. LEHR Project Status, Characterization and Monitoring. December 7, 1995.

Pacific Northwest Laboratory (PNL). 1995. Quarterly Ground water and Surface Water Monitoring Results, winter and Spring Quarters, 1995. November 1995. 
Appendix 8A

Preliminary Estimate of First Hydrostratigraphic Unit Vertical Hydraulic Conductivity

PRELIMINARY EVALUATION OF WATER LEVEL ELEVATION CHANGES IN MONITOR WELLS AT THE LEHR/UCD FACILITY, DAVIS

In an endeavor to gain a more through understanding of the dynamics of the groundwater regime monitored at the LEHR facility, stevens type $F$ continuous water level recorders were installed at the site by SWRCB/AIP staff to chart daily fluctuations in water level elevation in three monitoring wells. of primary interest was to determine if agricultural and domestic groundwater pumpage south of the LEHR facility could induce significant changes in the "normal" groundwater flow direction (to the northeast).

\section{BACKGROUND}

Vertical Gradient

on July 13, a water level recorder was installed on well UCD1-13. The well is located about 12 feet northerly of UCD2 -14 .

Assumptions :

HSU1 specific Yield $\left(S_{y}\right)$ and effective porcsity $\left(n_{e}\right)=8 \%$.

Declining water level elevation in the HSUl is a consequence of vertical gradients, the horizontal component of flow is negligible.

PRELIMINARY ESTIMATE OF VERTICAL HYDRAULIC CONDUCTIVITY AT LEHR WELI PAIR UCD1-13 AND UCD2-14

By assuming a specific yield of $8 \%$ for HSU1 and that groundwater movement is essentially vertical for the data considered, the hydraulic conductivity of these sediments can be estimated using the relationship:

$K=q \div I I d h / d I$

where $K$ = hydraulic conductivity

$q=$ rate of flow/unit area

$\mathrm{dh} / \mathrm{dl}=$ hydraulic gradient

The rate of flow can be estimated by assuming vertical flow in the unit and thus the daily decline in the water level represents the rate the sediments are dewatered. With the 
assumed specific yield of $8 \%$, the rate of flow/unit area can be estimated.

Daily Decline of water level (Jul $8-13$ ) $=0.14$ feet $/$ day Flow rate $/ \mathrm{ft}^{2}=.08 \times 7.48 \mathrm{gal} / \mathrm{ft}^{3} \times 0.14 \mathrm{ft} /$ day $=$ $0.084 \mathrm{gal} / \mathrm{day} / \mathrm{ft}^{2}$

Daily Decline of water level (Jul $14^{-}-18$ ) $=0.35$ feet/day Flow rate $/ \mathrm{ft}^{2}=.08 \times 7.48 \mathrm{gal} / \mathrm{ft}^{3} \times 0.35 \mathrm{ft} /$ day $=$ $0.21 \mathrm{gal} / \mathrm{day} / \mathrm{ft} \mathrm{t}^{2}$

Given these flow rates and the observed hydraulic gradients, the hydraulic conductivity can easily be estimated for the two time frames.

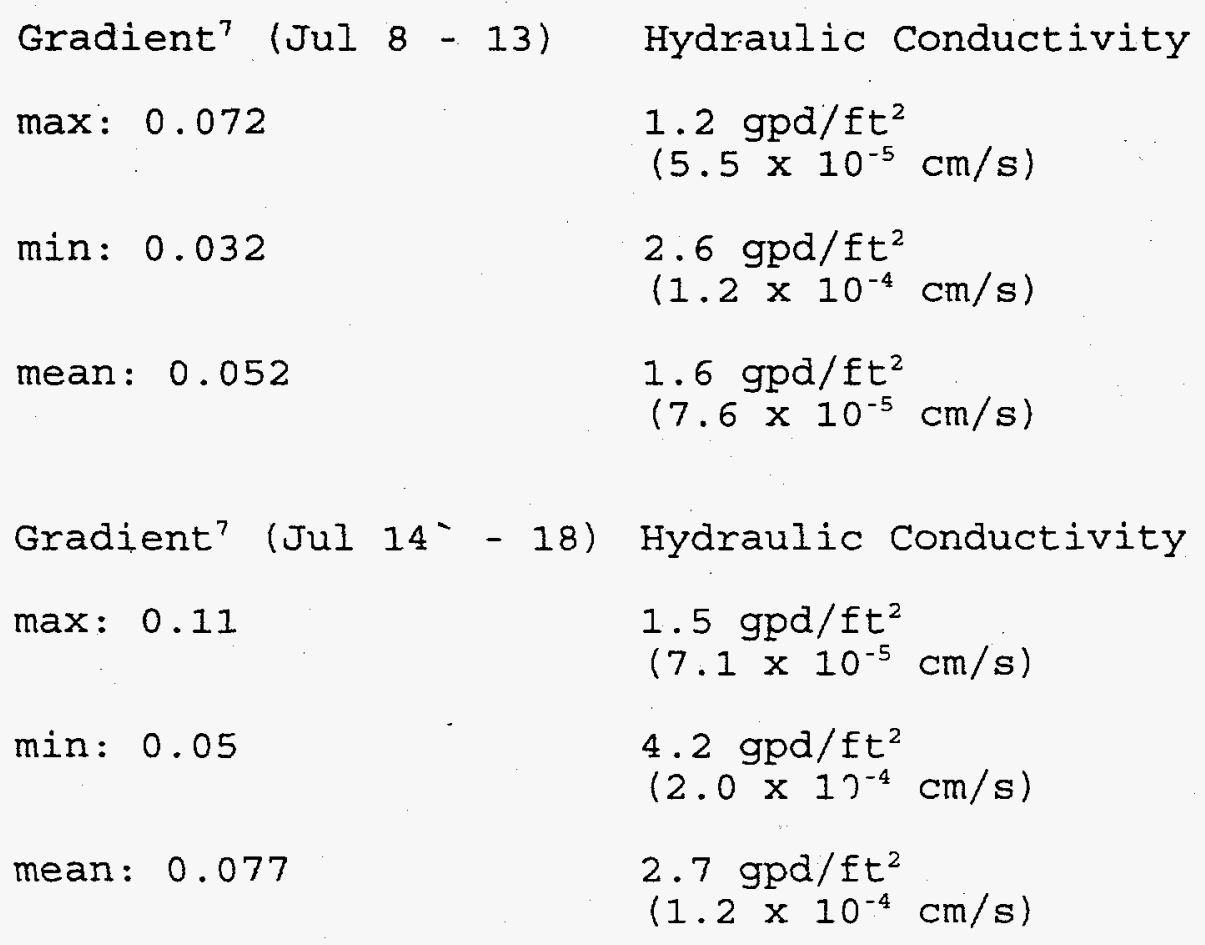

7 head differential divided by the distance between the midpoint of the well screens (22.5 feet). 


\section{APPENDIX 8B}

\section{INVENTORY OF WATER SUPPLY WELLS ${ }^{8}$ WITHIN 3 MILES EAST AND NORTHEAST OF THE UCD/LEHR FACILITY NEAR DAVIS, CA.}

compiled by:

Dennis Parfitt, CEG 1223

September 1995

State Water Resources Control Board

Sacramento, CA

T8N R2E MDBM

well\# use owner ${ }^{9}$ depth of boring/perforated interval (s)

11R dm City of Davis $T D=510^{\prime}$, perf'd 250-260, 294-320,

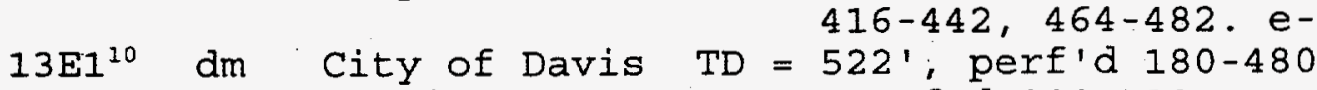

$13 \mathrm{E} 2 \mathrm{dm}$ Garritson $\mathrm{TD}=336^{\prime}$, perf'd 290-330

$13 E 3 \mathrm{dm}$ Garritson $\mathrm{TD}=336^{\prime}$, perf'd 290-330

$13 \mathrm{E} 4 \mathrm{dm}$

$13 \mathrm{~F} \quad \mathrm{dm}$

$13 \mathrm{H} 1 \mathrm{dm}$

$13 \mathrm{H} 2 \mathrm{dm}$

Willow Bank TD $=324$ ', perf'd 264-316

Bueri $T D=148^{\prime}$, perf'd $132-148$

$13 \mathrm{H} 3 \mathrm{dm}$

Howell TD $=320^{\prime}$, perf'd 240-300

$13 \mathrm{MI} \quad \mathrm{ag}$

$13 \mathrm{M} 2 \mathrm{dm}$

$13 \mathrm{M} 3 \mathrm{dm}$

$13 \mathrm{~N} d \mathrm{dm}$

$1301 \mathrm{dm}$

$13 Q 2$ ag

$14 \mathrm{~L} \quad \mathrm{dm}$

Reitan $T D=331^{\prime}$, perf'd 94-135, 269-310

$14 \mathrm{~J} 3$ ag

$14 \mathrm{KI}$ ag

$14 \mathrm{~K} 2$ ag

abandoned

$14 \mathrm{M} 3 \mathrm{dm}$

$14 \mathrm{Q} \mathrm{dm}$

Martin

$\mathrm{TD}=335^{\prime}$, perf'd 100-160,220-310

Hamel TD $=286^{\prime}$, perf'd 70-286

Heidrick TD $=360^{\prime}$, perf'd 267-334; abandoned

City of Davis abandoned

Heidrick TD $=332^{\prime}$, perf'd 140-160, 250-330;

$14 \mathrm{Q} 2 \mathrm{dm}$

Johnson

$T D=204^{\prime}$, perf'd 192 to $200^{\prime}$

Glaeser

$\mathrm{TD}=286^{\prime}$, perf'd 262-282

15J1 ag

Lederer

$\mathrm{TD}=318^{\prime}$, perf'd 255-279

$15 \mathrm{~J} 2$ ag

Hamel

$\mathrm{TD}=150 \%$, gravel from 136 to 148

$188,212-287$

$15 \mathrm{~K} 1 \mathrm{dm}$

Oeste

$\mathrm{TD}=287^{\prime}$, perf'd 108-125, 133-139,

$15 \mathrm{~K} 2$

Rust

$15 \mathrm{~K} 3$

$\mathrm{dm}$

Nishi?

$\mathrm{TD}=270^{\prime}$, perf'd 240-260

dm Hamel

$\mathrm{TD}=130^{\prime} ? ?$

\footnotetext{
${ }^{8}$ field located in September 1995.

gname appearing on the well Iog or owner identified during well search.

${ }^{10}$ up to five additional domestic water wells are located in the south half of the NW/ of section 13 .
} 


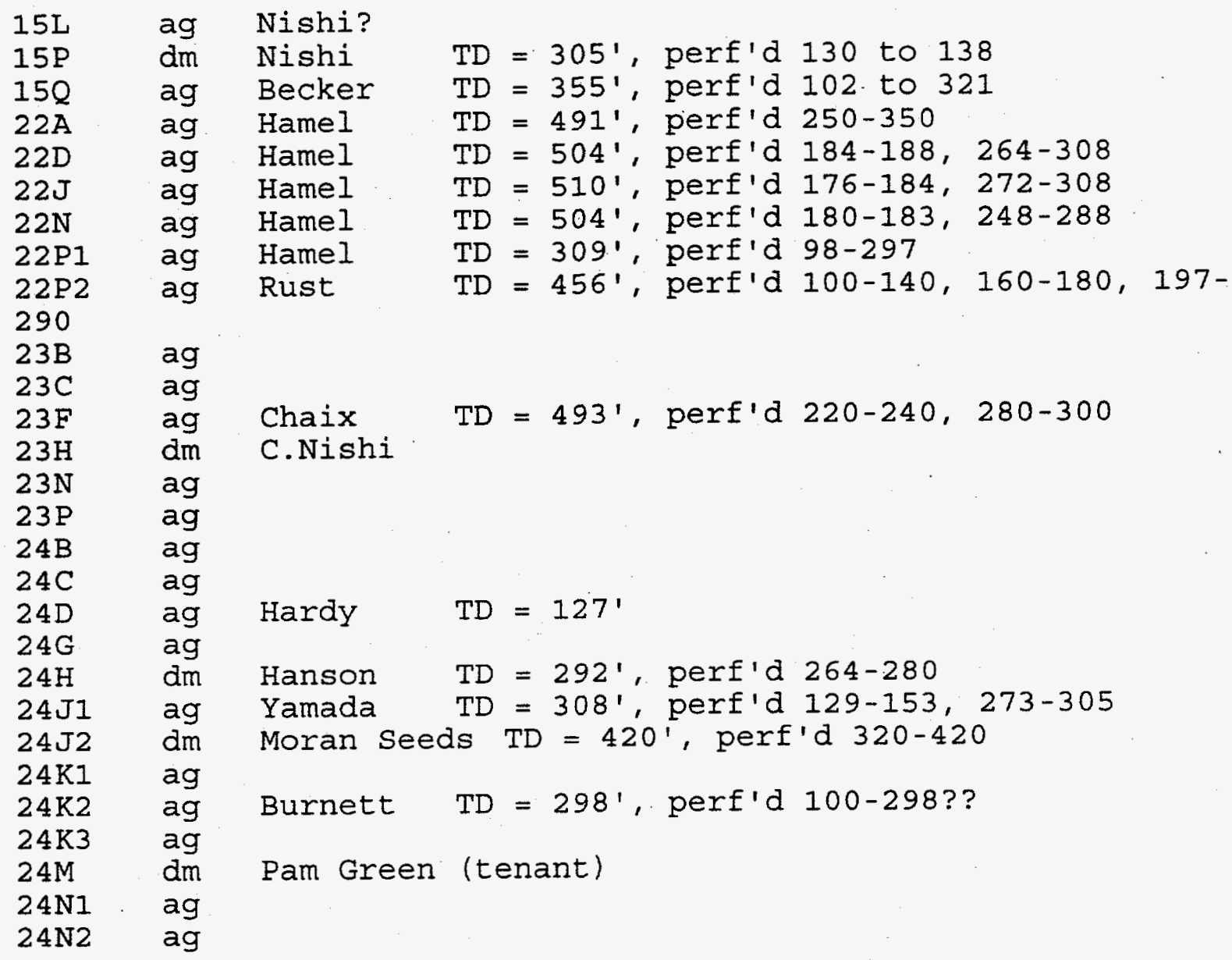




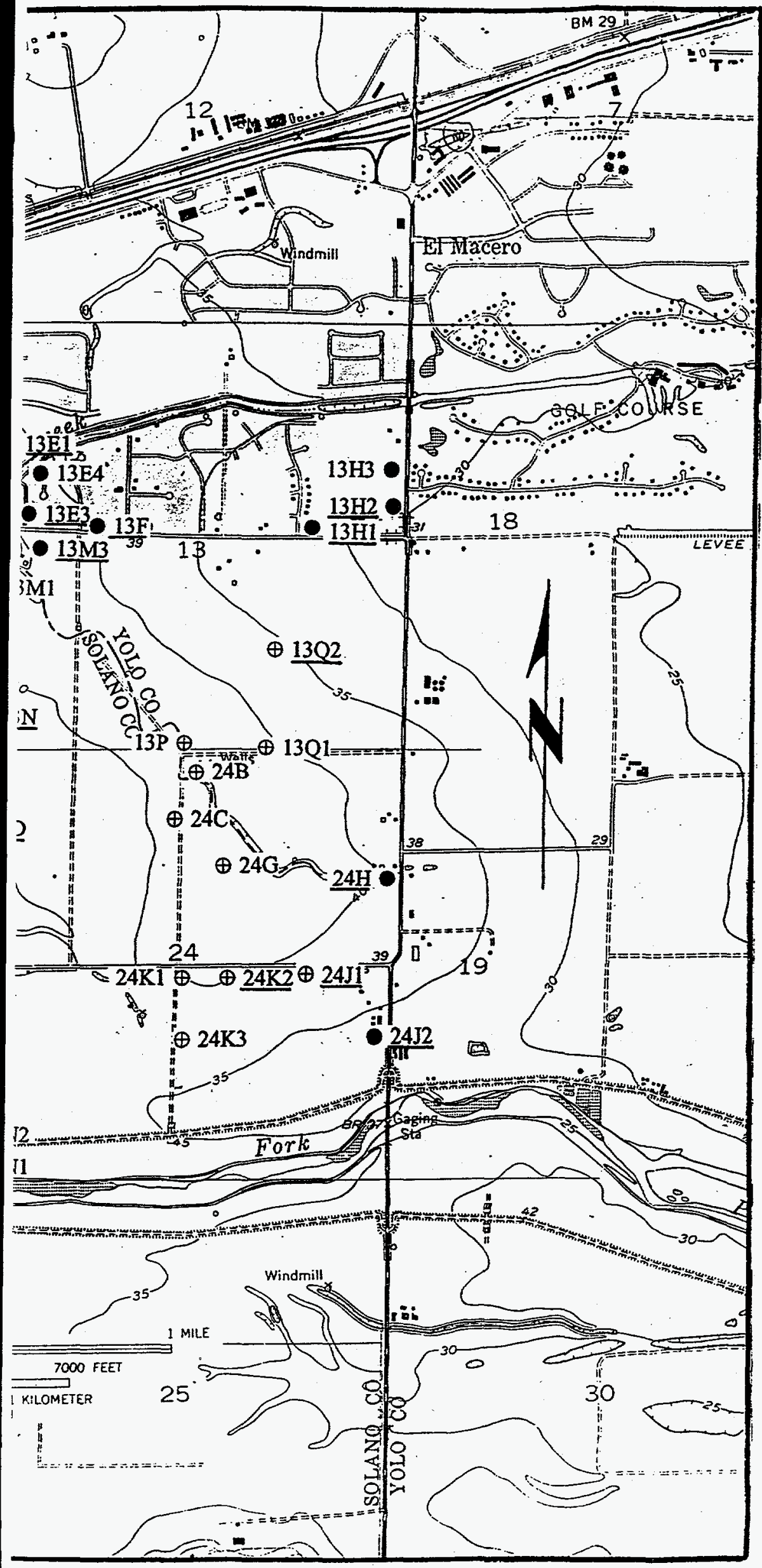

\section{WATER SUPPLY WELL LOCATION MAP}

wells within 3 miles east and northeast of the UCD/LEHR facility near Davis, CA

\section{LEGEND}

\section{- DOMESTIC WATER SUPPLY WELL}

\section{$\oplus$ AGRICULTURE WATER SUPPLY WELL}

\section{ه ABANDONED WELL}

Notes:

Well driller's report available for underlined well numbers.

Well numbers are not necessarily official state well numbers.

prepared by:

Dennis Parfitt, CEG 1223

State Water Resources Control Board Sacramento, $\mathrm{Ca}$

September 1995 


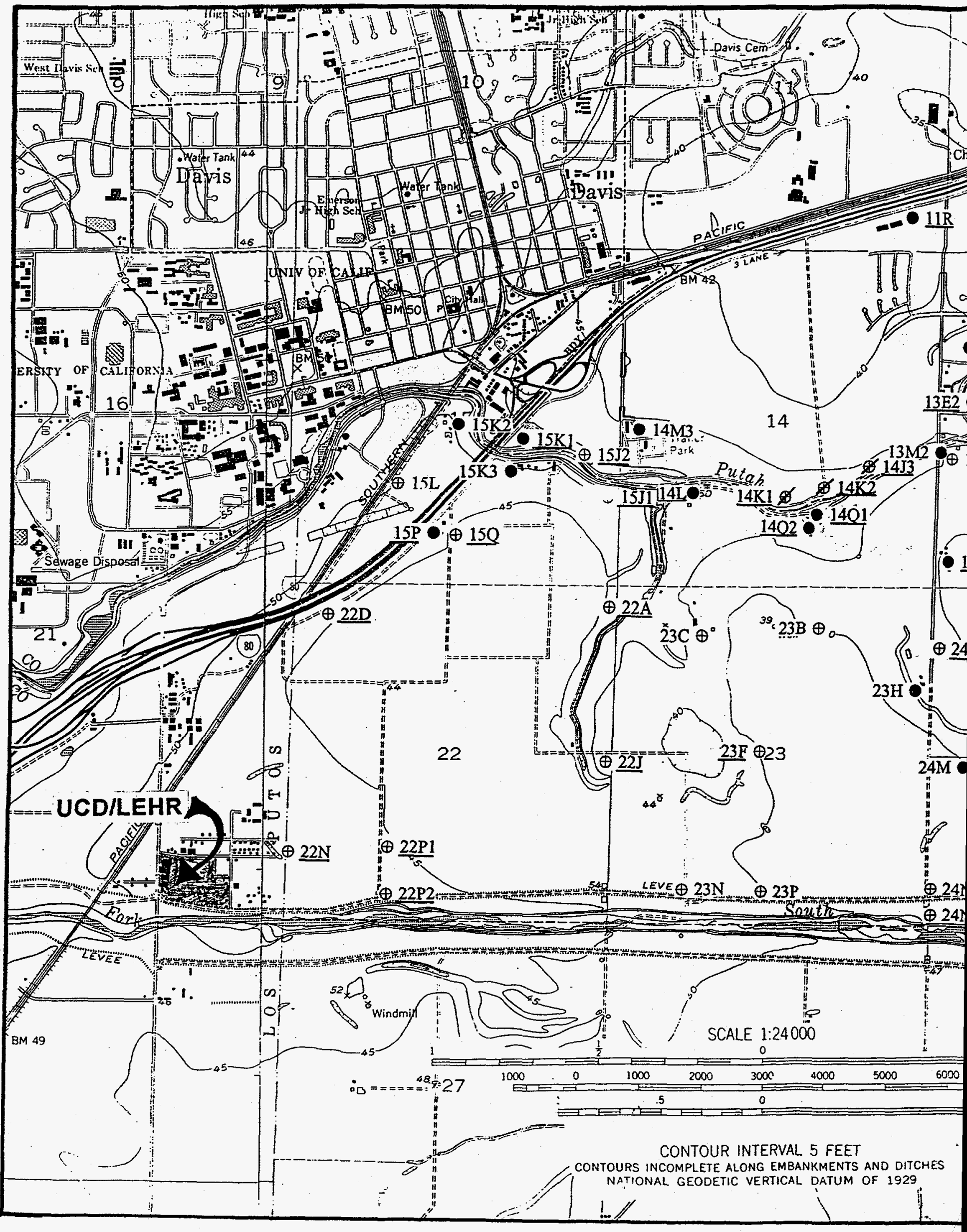

